\title{
Studies on the chemical nature of procoagulant sites on phospholipid vesicles and platelet membranes
}

Citation for published version (APA):

Speijer, J. G. (1987). Studies on the chemical nature of procoagulant sites on phospholipid vesicles and platelet membranes. [Doctoral Thesis, Maastricht University]. Rijksuniversiteit Limburg. https://doi.org/10.26481/dis.19871218js

Document status and date:

Published: 01/01/1987

DOI:

10.26481/dis.19871218js

Document Version:

Publisher's PDF, also known as Version of record

\section{Please check the document version of this publication:}

- A submitted manuscript is the version of the article upon submission and before peer-review. There can be important differences between the submitted version and the official published version of record.

People interested in the research are advised to contact the author for the final version of the publication, or visit the DOI to the publisher's website.

- The final author version and the galley proof are versions of the publication after peer review.

- The final published version features the final layout of the paper including the volume, issue and page numbers.

Link to publication

\footnotetext{
General rights rights.

- You may freely distribute the URL identifying the publication in the public portal. please follow below link for the End User Agreement:

www.umlib.nl/taverne-license

Take down policy

If you believe that this document breaches copyright please contact us at:

repository@maastrichtuniversity.nl

providing details and we will investigate your claim.
}

Copyright and moral rights for the publications made accessible in the public portal are retained by the authors and/or other copyright owners and it is a condition of accessing publications that users recognise and abide by the legal requirements associated with these

- Users may download and print one copy of any publication from the public portal for the purpose of private study or research.

- You may not further distribute the material or use it for any profit-making activity or commercial gain

If the publication is distributed under the terms of Article $25 \mathrm{fa}$ of the Dutch Copyright Act, indicated by the "Taverne" license above, 


\section{STUDIES ON THE CHEMICAL NATURE OF PROCOAGULANT SITES ON PHOSPHOLIPID VESICLES AND PLATELET MEMBRANES}

\section{Proefschrift}

ter verkrijging van de graad van doctor in de geneeskunde aan de Rijksuniversiteit Limburg te Maastricht, op gezag van de Rector Magnificus, Prof. Dr. F.I.M. Bonke, volgens besluit van het College van Dekanen, in het openbaar te verdedigen op vrijdag 18 december 1987 des namiddags om 14.00 uur

door

Johan Gerhard Speijer

geboren te Eindhoven

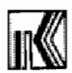

1987

Druk: Krips Repro Meppel 
Promotor : Prof. Dr. R.F.A. Zwaal

Co-promotor : Dr. J. Rosing

Referenten : Prof. Dr. B.N. Bouma

Dr. WTh. Hermens

Het onderzoek werd uitgevoerd bij de vakgroep Biochemie van de Rijksuniversiteit Limburg in samenwerking met Jan Rosing, José Govers-Riemslag en Rob Zwaal en werdl gesubsidieerd door de Stichting voor Medisch Onderzoek en Gezondheidsonderzoek (MEDIGON/ZWO).

In de drukkosten van het proefschrift werd bijgedragen door de Nederlandse Hartstichting.

Het manuscript werd getypt door Mariet Molenaar-v.d. Voort.

Omslag: Jaap Speijer. 


\section{CONDENTS}

Abbreviations

Chapter I

Chapter II

Chapter III

Chapter IV

Chapter v

Chapter VI

\section{INTRODUCTION}

THE EFFECTS OF BOVINE PROTHROMB IN FRAGMENT 1 AND FRAGMENT 1.2 ON PROTHROMBIN ACTIVATION. based on:

Govers-Riemslag, J.W.P., Speijer, H., Zwaal, R.F.A. and Rosing, J. (1985)

Thromb. Res. 38, 375-388.

VEMOM OF OXYURANUS SCUTELLATUS (TAIPAN SNAKE)

based on:

Spel jer, H., Govers-Rlemslag, J.W.P., Zwaal, R.F.A. and Rosing, J. (1986)

J. Biol. Chem. 261, 13258-13267.

Govers-Riemslag, J.W.P., Spel Jer, H., Zwaal, R.F.A. and Rosing, J. (1987)

In "Animal Venons and Hemostasis" (Plrkle, H. and Markland Jr., F..S., eds.) Marcel Dekker inc., New York, in press.

PLATELET PROCOAGULANT PROPERTIES STUDIED WITH SNAKE VENOM PROTHROMBIN ACTIVATORS based on:

Spei jer, H., Govers-Riemslag, J.W.P., Zwaal, R.F.A. and Rosing, J. (1987)

Thromb. Haemostasis $57,349-355$.

THE EFFECT OF SURFACE CHARGE OF PHOSPHOLIPID

VESICLES ON THEIR ACIIVITY IN PROTHROMBIN ACTIVATION based on:

Rosing, J., Speljer, H. and Zwaal, R. F.A. in "Current Advances in V1tamin K Research", Proc. of the Seventeenth Steenbock Sympositum (Suttie, J.W.,ed.) Elsevler North Holland, in press. Rosing, J., Speljer, H. and Zwaal, R.F.A. Blochemistry, in press.

GENERAL DISCUSSION

Sumemary

Samenvatting

Curriculum witae 
ABBREVIATIONS

Dangy $1-\mathrm{Glu}-\mathrm{Gly}-\mathrm{Arg}-\mathrm{CH}_{2} \mathrm{Cl}$
DEAE
EDTA
F1
F1.2
G1a
HPLC
HSA

$\mathbb{1} 2581$

$M_{r}$

PA

$\mathrm{PC}$

PG

PI

PLac

PS

Phe-Pro-Arg- $\mathrm{CH}_{2} \mathrm{Cl}$

phosphollpase $A_{2}$

$\mathrm{p}-\mathrm{NPGB}$

$\mathrm{QAE}$

RVV $-\mathrm{X}$

SDS

$\mathrm{SP}$

STI

$\$ 2222$

$\$ 2238$

$\$ 2337$
Dans y 1-l-glutamy 1-gl ycy 1-L-arginine

chloromethyl ketone dihydroctioride

Diethylam 1 noethy 1

Ethylenediaminotetraacetic acld

Prothrombin fragment 1

Prothrombin fragment 1.2

$y$-carboxyglutamic acid

High Performance Liquid Chromatography

Human Serum Albumin

N-dansy 1 - ( p-guanid Ino) phenylalanine-piperidide hydrochloride

Relative molecular weight

1, 2-dioleoy1-sn-g1ycero-3-phosphate

1,2-d1oleoy1-sn-g1ycero-3-phos phocholine

1,2-dioleoy1-sn-glycero-3-phosphog1ycerol

1,2-d1oleoy1-sn-glycero-3-phos pholnositol

1,2-dioleoy1-su-glycero-3-phospho- $\beta$-1actate

1,2-dioleoy 1-sn-glycero-3-phos phoserime

D-phenylalanyl-L-prolyl-L-arginine chloromethyl ketone dihydrochlorlde

Phospatide 2-acylhydrolase

p-nitropheny1-p'-guanId Inobenzoate

Quaternary anlnoethy 1

Factor $X$ activator purifled from Russe11"s Viper venom

Sodtum dodecyl sulphate

Sulfopropy1

Soybean trypsin Inhibitor

$\mathrm{N}$-benzoy $1-\mathrm{L}-1$ soleucy $1-\mathrm{L}-\mathrm{g} 1$ ut any $1 \mathrm{~g} 1$ ycy $1-\mathrm{L}-$ arginine-p-nitroanilide hydrochloride

H-D-phenylalany1-L-pipecolyl-L-arginine-pnitroanilide dihydrochloride

$\mathrm{N}$-benzoy1-L-1soleucy1-L-glutamyl(plperidy1)

glycyl-L-arglnine-p-nitroanilide hydrochloride 
CHAPTER I

INTRODUCTTON

In blood several components are present that provlde for coagulant and anticoagulant mechanisms. A dellcate balance between these mechanisms previlis, which normally is in favour of antlcoagulation to keep the blood fluid. Nevertheless, procaagulant reactions are temporarily triggered at a site of vessel wall damage to produce a hemostatlc plug that arrests bleeding. A permanent imbalance to efther side, however, has rather profound Implications: bleeding disorders, on the one hand, or thrombosis and cardlovasicular disease on the other. Understanding the hemostatic processes is necessary for active prevention of hemostatic malfunctions and for the development of rational therapeutical approaches. Furthemore, studles of hemostasis, with its complicated chemtcal reactions and Interactions, w11 extend our insights in the fundamentals of protein and lipid blochemistry. The next paragraphs wl1 glve a short general Introduction to hemostasis and discuss in more detall those aspects of the hemostatic process that are subject of this thesis.

The process of blood coagulation. Hemostasis covers several sequential steps which can be divided into two pathways as is shown in a simplifled scheme In Fig. 1. Platelets are small, stlcky, discold blood cells, whlch adhere to exposed collagen fibres at a stte of vessel wall infury. Hare they become activated, change shape and release several components, some of which may stimulate other platelets from the blood stream to adhere, and thus form a platelet aggregate (1). Slmultaneously the damaged vessel wal1 inttiates the coagulation cascade: clotting factors, circulating in the blood as Inactive zymogens, become successively activated (2). This finally leads to the formation of thrombln, a proteolytic enzyme, which plays key role in hemostasis. One of the functions of thrombln is the enzymatic conversion of ftbrinogen to flbrin. The flbrin monomers that are formed crosslink to produce polymer threads, which strengthen the platelet aggregate to render the hemostatic plug. Thrombin, 11ke collagen, also has 


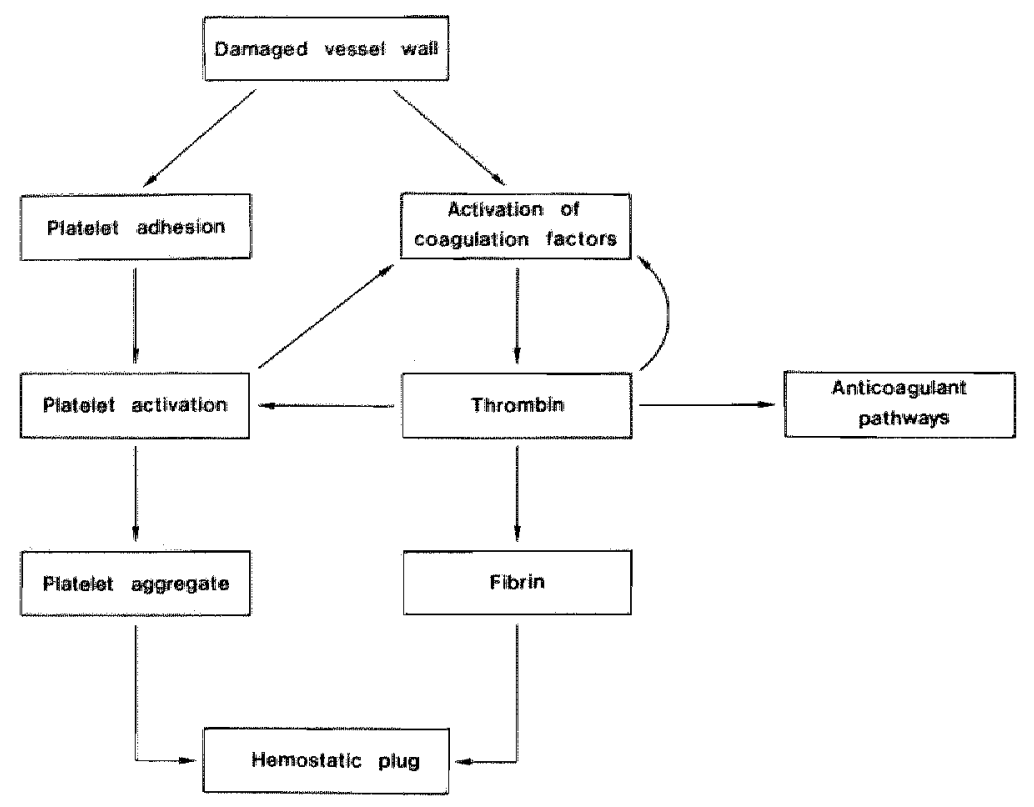

Fig. 1. Schematic representation of the hemostatic process

the ability to induce platelet activation and aggregation. Activated platelets expose a procoagulant surface to which the coagulation factors may bind. Thus, platelets promote the interaction and activation of the clotting factors (3). Furthermore, thrombin activates in a feedback reaction Factors $V$ and VIII, and so accelerates 1 tg own formation. A fourth Important property of thrombin 1 s that it inftiates anticoagulant pathways (4). This leads to the control of the hemostatic process and finally to the restoration of the subtile interplay of coagulant and anticoagulant reactions.

From this, it is clear that thrombin is a central conponent in blood coagulation. The mechanism of $1 \mathrm{ts}$ generation $1 \mathrm{~s}$ therefore of spectal Interest.

The conversion of prothrombin to thrombin. Thrombin is formed due to partial proteolysis of the zymogen prothrombin by Factor Xa (5), a serine protease that orfginates from its precurgor Factor $X$ earlier in the coagulation cascade. Prothrombin activation by Factor $\mathrm{Xa}$ alone is a very 
slow process. The reaction is, however, enomously accelerated in the presence of negatively charged phospholiplds, calclum lons and the nom-enzymatic protein cofactor Va $(6)$. The phospholipids prowlde a membrane surface to which Factor Xa, Factor Va and prothrombln bind $(6,7)$, and thus promote the interactions of these coagulation factors, while Factor Va has a wajor effect on the catalytic efflciency of Factor Xa (see below).

In the last two decennia much information has been obtalned regarding the proteins involved in prothrombin activation. The protelns have been purlfied to homogenelty and structural and functlonal properties have been established. Fig. 2 shows some of the characterlstics of these protelns.

Factor Xa is a glycoprotein, with a molecular welght of 45,000 , that consists of two disulfide-1inked polypeptide chains $(8,9)$. The 1 ight chatn $\left(M_{r} 18,000\right)$ of Factor $X a$ contalns $p$-carboxyglutamic acid (Gla) restdues (10), which are essential for the calcium-dependent binding of Factor Xa to procoagulant phospholipid surfaces $(11,12)$. The heavy chain $\left(M_{r} 27,000\right)$ of Factor Xa contains the active stte region of the molecule and has a high degree of amino acld sequence homology with trypsin (13).

$M_{\mathrm{r}}$

FACTOR $x_{a}$

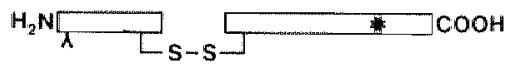

45000

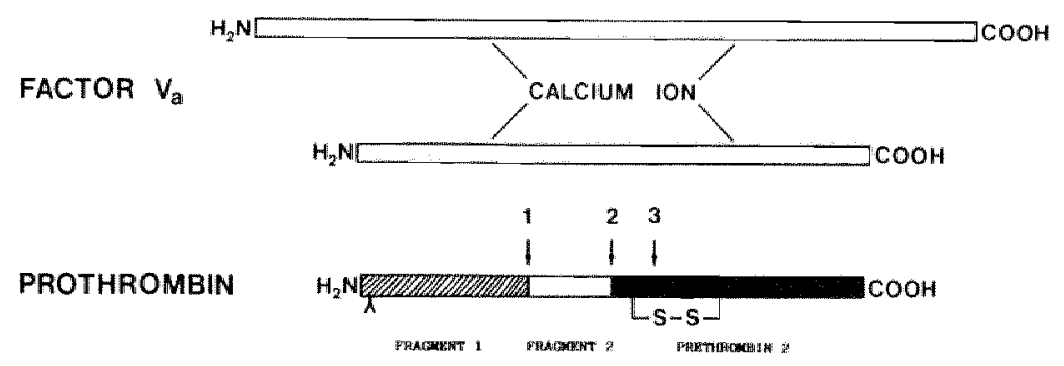

105000

74000

72000

* active site serine

A. ,-carboxyglutamic acid 
Pactor Va 18 a glycoprotein with a molecular weight of 180,000 that is coriposed of a heavy chaln of $M_{r} 105,000$ and a 1 ight chain of $M_{r} 74,000$ (14). The two chains are non covalently associated through a calcium bridge. Factor Va is thought to blind to negatively charged phospholiplds through the 11 ght chaln $(15,16)$. Detalls of the blnding characteristics are not known, although both hydrophoblc (15) and lonic (16) interactions have been reported.

Prothrombln is a single chain glycoprotein with a molecular weight of 72,000, which consigts of three functional domalns. The fragment 1 region contalns the Gla residues (17), which are thought to be directly involved In the calclum-mediated binding of prothrombin to negatively charged phospholipids. A number of studies indicate, however, that some of the Gla's may also be Involved In a calcium-1nduced conformational change of the prothrombin molecule, that is essentlal for blological activity $(18,19,20)$. The fragment 2 region 1 s the part of the proteln that $1 \mathrm{~s}$ thought to interact with the protein cofactor Va (21). It is followed by the so-called prethrombin 2 region. From this region the trypsin-like serine protease thrombin is actually generated after $11 \mathrm{mited}$ proteolysis of prothrombin by Factor Xa (22).

Three bonds in the prothrombin molecule are susceptible for proteolytic cleavage. Cleavage at bond $1\left(\operatorname{Arg}_{156}-\operatorname{Ser}_{157}\right)$ is catalyzed by thrombin, rendering fragment 1 and prethrombin 1 . Since prethrombin 1 lacks the membrane binding domaln of prothrombin lt $1 \mathrm{~s}$ a poor substrate for membrane-bound Factor $\mathrm{Xa}$ and thromb1n therefore Imposes a negative feedback on 1 ts own formation.

Factor Xa can hydrolyse the $\operatorname{Arg}_{274}-\operatorname{Thr}_{275}$ bond (site 2) and the $\operatorname{Arg}_{323}-\operatorname{lle}_{324}$ bond (ste 3) of prothrombin. Silnce both peptide bonds have to be cleaved during the conversion of prothrombin into thrombin, there are actually two possible pathways of prothrombin activation (Fig. 3). By route A, first site $2 \mathrm{is}$ cleaved, rendering the activation peptide fragment 1.2 and prethrombin 2, catalytically inactive Intermediate. Subsequently Factor Xa splits prethrombin 2 at site 3 to give thrombin. In pathway $B$, the reversed order of bond cleavage is followed, ylelding the intermediate melzothrombin, which has its catalytic site exposed and is fully active towards small synthetic substrates, but which has a diminished clotting activity (23). Depending on the reaction conditions chosen both 


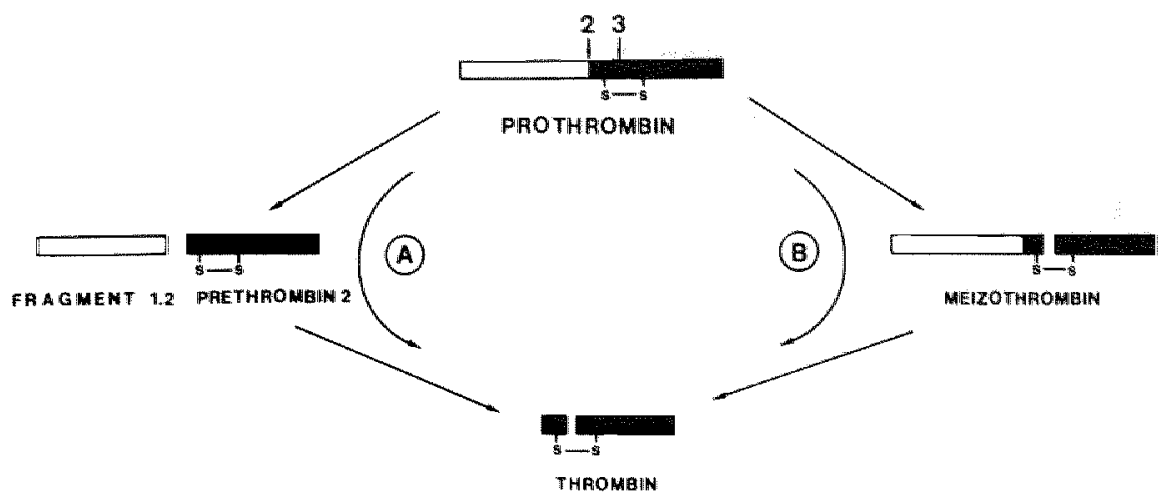

Fig. 3. Pathways of prothrombin activation

Intermediates prethrombin 2 (24) and melzothrombin (25) can be generated, Indlcating that thrombln may be formed via both pathways.

The function of phospholiplds in prothrombin activation. Kinetic experiments have shown that phosphollplds exert thefr effect on the rate of thrombin formation by a drastic decrease of the $\mathrm{Km}$ for prothrombin to levels below the plasma concentration (26). Moreover, phospholiplds enhance the binding affinity of Factor Xa for Factor Va, which form tight, lipld-bound enzymatic complex called prothrombinase $(27,28)$.

Two models have been proposed to explain the effects of phosphollptds on the $\mathrm{Km}$ for prothrombin conversion. In the so-called "bound substrate" mode1, phosphollplds are viewed as a surface to which the enzyme factor Xa and the substrate prothrombin bind, thereby ralsing their local concentrations and thus promoting their abllity to Interact and react with each other $(26,29,30)$. LIpid-bound Factor Xa converts 11pld-bound prothrombin and the increased prothrombin concentration at the 11 pld-water Interface explains the decrease of the observed Km. The model was aupported by the observation that the density of prothrombln at the membrane surface appeared to determine the reaction kimet1cs of prothrombin activation (26).

Nelsestuen proposed the "free substrate" model (31), In which prothrombinase is deplcted as a dissoctable three-component enzyme (Tactor XaFactor Va-phospholipid) that conwerts soluble prothrombin. He guggested that membranes Impose their effect on the Km for prothrombin by virtue of 
the additive free energles of prothrombin-phospholipid and prothrombinFactor Va lnteractions, which occur at the active site of prothrombluase $(31,32)$. Experiments th membranes that have a low blnding affinity for prothrombin mistain these views $(33,34)$. The Km for prothrombin activation. on wheh membranes in the presence of Factor Va was much lower than could be expected from the 1 ipld-binding parameters of prothrombin. Van Rijn et al. (33) demonstrated that prothrombin activation with or without Factor Wa cannot be described by one made1. In the presence of Factor Va free prothrombln appears to govern prothrombinase activity, while in the absence of Factor Va, the effect of phosphollpids on the observed $\mathrm{km}$ is qualitatively best explatned in the bound-substrate model.

The function of Factor Va in prothrombin activation. The effect of Factor Va on the kinetic parameters of prothrombin activation has been the subject of a number of studies $(26,27,33,34)$. Factor Va dramatically increases the Vmax of prothrombin conversion $(26,27)$, while a decrease of the km for prothrombin is also observed, a feature whlch becomes most apparemt on membranes with a low binding affinity for prothrombin $(33,34)$.

The effect on the Vmax appears to be threefold. Factor Va ralses the $k_{\text {cat }}$ of thrombin formation more than 1000 times. Whether $1 t$ exerts this effect by making Factor Xa a better enzyme, or by modifying the prothrombin molecule, to make 1t more susceptible for proteolytic cleavage by Factor $\mathrm{Xa}$, remains unclear.

Factor Va also promotes the binding of Factor Xa to metibrames. It forms a stolchiometric (1:1) complex with Factor Xa $(27,28,35)$ with a high affintty for phospholipld surfaces. "Thus Factor Va enhances the anount of Xa molecules bound at the membrane and participating in prothrombin activation.

Finally, Factor Va effectuates a shift in the pathway of thrombin fomation (F1g. 3). In the absence of Factor Va, large amounts of prethrombin 2 are generated, which are only slowly converted into thrombin $(26,36)$. In the presence of factor $\mathrm{Va}$, however, there is no detectable prethrombin 2 formation, but substantlal amounts of melzothrombin appear as an Intermediate product, which are rapldiy turned over to thrombln (25).

Two mechantsms have been suggested to explain the effect of Factor Va on the $\mathrm{Km}$ for prothrombin activation. The observation that Factor Va induces 
clustering of anlonic phosphollplds (37) led to the proposal that this process contributes to the assembly of the prothrombinase complex. Whether this phenomenon results in the enhancement of the binding affindty of prothrombin for membranes remalns to be established.

A direct interaction between Factor Va and prothromin through 1 ts fragment 2 region (21) has also been proposed to account for the Va induced Ancrease of prothrombin-prothrombinase binding affinlty. Support for this possibllity came from studles whlch showed that factor Va enhanced the binding of prothrombin to phasphollpid membranes (38). Neverthelless, quantitative data are lacking to relate the effect of Factor Va on the Km to its effect on the prothrombin binding to phosphollpids.

Prothrombin activation on cellular surfaces " Coagulation factor activation in vivo is thought to proceed on membranes provided by cells in contact with the blood, such as platelets, endothellal cells, 1ymplocytes and monocytes. Most extensively studed are blood platelets which are reported to promote both prothrombin as well as Factor $x$ activation $(39,40)$. In vitro, intrinsic factor $X$ activation proceeds by means of "tenase", a complex which 11ke prothromblnase conslsts of an enzyme (Factor IXa), a protein cofactor (Factor VIIIa) and a phospholipid surface $(2,41,42)$.

It has been suggested that anfonic platelet phosphollplds account for the procoagulant activity of platelets $(43,44,45)$. Unstimulated- and thrombln stimulated platelets have a low procoagulant activ1ty (46). When platelets are stlmulated with collagen a 3- to 7-fold increase of the procoagulant activity is observed, while stimulation by the combined action of thrombin and collagen gives a 10- to 20-fold increase of the platelet procoagulant activity (46). Conconitant with an increase of procoagulant activity is an increase of the amount of exposed phosphatidylserine molecules, the major antonic phosholipld in the platelet plasma membrane $(44,45)$. In reating and thrombin stimulated platelets, phosphatidylserines are located almost exclusively in the cytoplasmlc leaflet of the plasma menbrane, but upon platelet activation wh thrombin plus collagen they are translocated by an as yet unknown mechanlsm to the outolde half of the membrame, where they become in contact with the blood. It has therefore been suggested that phosphatidylserine has an important function in the platelet procoagulant 
Bles that serve Pactor $X$ and prothrombln activation.

Purther evidence for this hypothesis came from studies on a patient with a bleeding dlaorder. It shown that the platelets of this patient had an Impalred Factor $X$ - and prothrombin-converting activity, which colncided wth the lack of ability to expose phosphatidylserines at the outside of the platelet plasma membrane (47).

other Invet 1 gators have proposed specific receptor proteins as binding ites for the coagulation factors. Such receptors would promote the atambly of prothramblnase and tenase complexes on cellular surfaces. A Factor Xa-speciflc receptor on the platelet surface was reported $(48,49)$, which was later identifled to be platelet-bound factor Va $(50,51)$. Studies of Factor Va-platelet interactions resulted in the postulation of a receptor proteln for Factor Va $(52,53,54)$, but its Identification was up to now not possible.

Recently, high affinity binding sites for Factor IX and Factor IXa on the endothella1 cell were described, that function in the Factor IXa-VIILa mediated activation of Factor $X$ (55). This endothelial cell surface receptor was 1dentifled to conslst at least in part of a membrane proteln (56). Such receptor proteing for Factor IX/IXa could, however, not be 1dentified on blood platelets (57). Therefore, the precise chemical nature of the procoagulant sites on blood cells $1 \mathrm{~s}$ st11 a matter of debate. The two concepts do, however, not exclude each other and both proteln and lipld components may be Involved in the binding of coagulation factors.

The present investigation. In this thesis studies on the molecular Interactions contributing to the action of prothrombinase on prothrombin are described. Prothrombin activation is studied on phospholipld vesicles as 11 as on platelet membranes.

During the catalytic conversion of prothrombln, the activation peptides fragment 1 and fragment 1.2 are released. Since both fragments contain the membrane blnding domaln of prothrombin, while fragment 1.2 has additional affinity for Factor Va via 1ts fragment 2 region, these activation peptides may Interfere with the Interactions of prothrombin wth the prothrombinase complex and thus inhlbit prothrombin activation. Chapter II describes the effects of fragment 1 and fragment 1.2 on prothrombin activation by Factor $\mathrm{xa}$ In the presence of varlous lipld mixtures efther with or whout Factor 
Va. The results presented in this chapter have lmplications for the mechanisus by which phosphollpids and Factor Va affect prothrombin activation.

A somewhat different approach for deriving information about the mode of action of the accessory components in thromblin formation, was found in studies of prothrombin activation by the prothrombln activator from the venom of oxyuranus scutellatus. This snake venom activator differs in deta11 from Factor Xa $(58,59)$ and hence may add to our knowledge of the interactions that are important in prothrombin conversion. chapter III describes the purification, the subunit structure and the catalytic properties of this venom enzyme. The venom activator is used as a tool in studying the platelet procoagulant sites (Chapter IV). platelets are stimulated with various triggers and their activity in prothrombin activation by Factor Xa is compared with their effect on the venonrcatalyzed prothrombin conversion. Also, the number of procoagulant sites for Factor $\mathrm{Xa}$ and for the venom enzyme on the platelet surface is determined while information on their chemical nature is inferred from experiments with phospholipase $A_{2}$.

Not much is known about the chemical and physical interactions important for membrame binding of the coagulation factors. In early expertments $t$ was shown that 1ipld surfaces need to possess a net negative charge in order to have a clot promoting activity (60). Furthermore, the activity of phospholipid surfaces depended on their electrostatic potential provided by antonic phosphollplds while the chemical nature of the antonic phosphoIlpids would be of minor importance (61). More recent experiments, however, demonstrate that, as far as prothromblnase 1 s concerned, there 18 no clear relation between the surface charge and the activity of phosphollpld vesicles $(33,34)$. Moreover, the kinetic parameters of prothrowbin conversiou depend on the type of anionic phosphollpid that 1 is present in the procoagulant membrane (33).

In Chapter $V$ experiments are outlined In which the surface charge of vestcles and the kind of anlonle phospholipld is varied, and their activity in prothrombin conversion is compared. The results favour a chelation model. for the calclum-dependent interactions of vitamin $\mathrm{K}$-dependent coagulation factors with phosphatidylserine molecules in the membrane. 
1. Zucker, M.B. and Nachinlas, V.T. (1985) Arteriosclerosis 5, 2-18.

2. Jackson, C.M. and Nemerson, Y. (1980) Ann. Rev. Biochem. 49, 765-811.

3. Beyers, E.M., Rostng, J. and Zwaa1, R.F.A. (1987) in Platelets in Blology and Pathology II (Macintyre and Gordon, eds.) 127-160, Rlaevier Siclence Publishers B.V. (Blomedical Division).

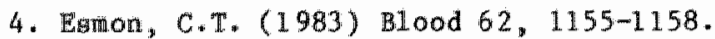

5. Suttle, J.W. and Jackson, C.M. (1977) Phys101. Rew. 57, 1-70.

6. Joblo, Jind Esnouf, M.P. (1967) Blochem. J. 102, 666-674.

7. Henker, H.C.., Esnouf, M.P., Hemker, P.H., Swart, A.C.M. and MacFarlane, R.G. (1967) Hature 215, 248-251.

8. Leveson, J.E. and Esnouf, M.P. (1969) Br. J. Haemato1. 17, 173-178.

9. Radcliffe, R.D. and Barton, P.G. (1972) J. Blol. Chem. 247, 7735-7742.

10. Bucher, D., Nebelin, E., Thomson, J. and Stenflo, J. (1976) FEBS Letters $68,293-206$.

11. Esmon, C.T., Suttie, J.W. and Jackson, C.M. (1975) J. Biol. Chem. 250, 4095-4099.

12. Nelsestuen, G.L., Broderlus, M. and MartIn, G. (1976) J. Biol. Chem. $251,6886-6893$.

13. Titand, K., Fuflkawa, K., Enfleld, D.L., Erlcsson, L.H., Walsh, K.A. and Neurath, H. (1973) Proc. Nat1. Acad. Sc1. U.S.A. 72, 3082-3086.

14. Esmon, C. T. (1979) J. Bio1. Chem. 254, 964-973.

15. Bloom, J.W., Neshedr, M.E. and Mann, K.G. (1979) Blochemistry 18, 4419-4.425.

16. van de Waart, P., Bruls, H., Hemker, H.C. and Lindhout, T. (1983) Blochemlstry 22, 2427-2432.

17. Magnusson, S., Sottrup-Jenssen, L. and Petersen, T.E. (1975) FEBS Letters $44,189-193$.

18. Nelsestuen, G.L. (1976) J. B1o1. Chem. 251, 5648-5656.

19. Furle, B.C., Blumensteln, M. and Furle, B. (1979) J. B1o1. Chem. 254, 12521-12530.

20. Borowsk1, M., Furie, B.C., Bauminger, S. and Furle, B. (1986) J. Biol. Chen. 261, 14969-14975.

21. Esmon, C.T. and Jackson, C.M. (1974) J. Biol. Chem. 249, $7791-7797$.

22. Butkowgk1, R.J., Ellon, J., Downing, M.R. and Mann, K.G. (1977) J. Bto1. Chent $252,4942-4957$.

23. Kornaldk, F and Blombäck, B. (1975) Thromb. Res. 6, 53-63.

24. Esmon, C.T., Owen, W.G. and Jackson, C.M. (1974) J. Biol. Chem. 249, $7782-7790$.

25. Rosing, J., Zwad, R.F.A and Tans, G. (1986) J. Biol. Chem. 261 , $4224-4228$.

26. Rosing, J., Tans, G., Govers-Riemslag, J.W.P., Zwaal, R.F.A. and Henker, H.C. (1980) J. B101, Chem. 255, 274-283.

27. Neshefm, M.F., Taswe11, J.B. and Mann, K.G. (1979) J. Biol. Chem. 254, 10952-10962.

28. LIndhout, T., Govers-Rlemslag, J.W.P., van de Waart, P., Hemker, H.C. and Rosing, J. (1982) Blochemlstry 21, 5495-5502.

29. Nesheim, M.E., Eid, S. and Mann, K.G. (1981) J. Bio1. Chem. 256, 9874-9882.

30. Neshe1m, M.E., Tracy, R.P. and Mann, K.G. (1984) J. Biol. Chem. 259, 1447-1453.

31. Nelsestuen, G.L. (1978) Fed. Proc. 37, 2621-2625. 
32. Nelsestuen, G.L. (1980) in The Regulation of Coagulation (Mann, K.G. and Taylar F.B., eds. $\$ 33-42$ Elsevier New York.

33. van Rijn, J.L.M.L., Govers-Rlemslag, J.W.P., Zual, R.F.A. and Roslng, J. (1984) Blochemlstry $23,4557-4564$.

34. Pusey, M.L. and Nelsestuen, G.L. (1983) Blochem. Blophys. Res. Commun. $114,526-532$.

35. Nesheim, M.E., Kettner, C., Shaw, E. and Mann, R.G. (1981) J. BHol. Chem. $256,6537-6540$.

36. Esmon, C.T., Owen, W.G. and Jackson, C.M. (1974) J. Biol. Chem. 249, $8045-804.7$.

37. Mayer, L.D. and Nelsestuen, G.L. (1981) Biochem1stry 20, 2457-2463.

38. van de Waart, P., Hemker, H.C. and Lindhout, T. (1984) Blochemistry 23, $2838-2842$.

39. Walsh, P.N. and Biggs, R. (1972) Br. J. Haematol. 22, 743-760.

40. Walsh, P.N. (1978) Br. J. Haematol. 40, 311-331.

41. van Dieljen, G., Tans, G., Rosing, J. and Hemker, H.C. (1981) J. Biol. Chem. 256, 3433-3442.

42. van Dieijen, G., van Rijn, J.L.M.L., Govers-Rlemslag, J.W.P., Hemker, H.C. and Rosing, J. (1985) Thromb. Haemost. 53, 396-400.

43. Bevers, E.M., Comfurius, P. and Zwa.1. R.F.A. (1982) Eur. J. Blochem. $122,81-85$.

44. Bevers, E.M., Comfurius, P. and Zwaal, R.F.A. (1982) Eur. J. Blochem. $122,429-436$.

45. Bevers, E.M., Comfurtus, P. and Zwal, R.F.A. (1983) Blachlm. Blophys. Acta $736,57-66$.

46. Rosing, J., van Rijn, J.L.M.L., Bevers, E.M., van Dielfen, G., Comfurlus, P. and Zwaal, R.F.A. (1985) Blood 65, 319-332.

47. Rosing, J., Bevers, E.M., Comfurtus, P., Hemker, H.C., van Dieljen, G., Welss, H.J. and Zwaal, R.F.A. (1985) Blood 65, 1557-1561.

48. Miletich, J.P., Jackson, C.M. and Majerus, P.W. (1978) J. B1ol. Chem. $253,6908-6916$.

49. Dah1båck, B. and Stenf1o, J. (1978) Biochemfistry 17, 4938-4945.

50. Tracy, P.B., Eide, L.L., Mann, K.G. (1985) J. Blol. Chem. 260, 2119-2124.

51. Tracy, P.B., Neshe1m, M.E., Mann, K.G., (1981) J. B101. Chem. 256, $743-751$.

52. Milet1ch, J.P., Kane, W.H., Hofman, S.L., Stanford, N. and Mallerus, P.W. (1979) Blood 54, 1015-1022.

53. Kane, W.H. and Majerus, P.W. (1982) J. Blol. Chem. 257, 3963-3969.

54. Tracy, P.B., Peterson, J.M., Neshe Im, M.E., MeDuffle, F.C., Mann, K.G. (1979) J. B1o1. Chem. 254, 10345-10361.

55. Stern, D.M., Nawroth, P.P., Kislel, W., Vehar, G. and Esmon, C.T. (1985) J. Blol. Chem. 260, 6717-6722.

56. R.Imon, S., Melamed, R., Savion, N., Scott, T., Nawroth, P.P. and Sterm, D.M. (1987) J. Bio1. Chem. 262, 6023-6031.

57. Stern, D.M., Knitter, G., Kistel, W. and Nawroth, P.P. (1987) Br. J. Haemato1. $66,227-232$.

58. Owen, W.G. and Jackson, C.M. (1973) Thromb. Res. 3, 705-714.

59. Walker, F.J., Owen, W.G. and Esmon, C.T. (1980) Blochemlstry 1.9, 1020-1023.

60. Bangham, A.D. (1961) Nature 192, 1197-1198.

61. Papahadjopoulos, D., Hougle, C. and Hanman, D.J. (1962) Proc. Soc. Exp. Bilo1. Med. 111, 412-416. 

CEAPTER II

THE EFFECTS OF BONINE PROTHROMBIN FRAGMENT 1 AND FRAGMENT 1.2 ON PROTHROMBIN ACIVATION

SLMMARY

In this paper we describe the effects of the activation peptides prothrombin fragment 1 and fragment 1.2 on Factor Xa-catalyzed prothrombin activation. Prothrombin activation in free solution by elther Factor Xa or Factor Xa together with Factor Va is unaffected by the activation fragments. When negatively charged phosphollpids are present we observed considerable inhibition of prothrombin activation by both fragment 1 and fragment 1.2. For the activation of $0.25 \mu \mathrm{M}$ prothrombin by Factor Xa in the presence of $50 \mu \mathrm{M}$ phospholipld (phosphatidylserine/phosphatidylcholine, 25/75; mole/mole) and $5 \mathrm{mM} \mathrm{CaCl}$, $50 \%$ inhibition was obtalned at $0.28 \mu \mathrm{M}$ fragment 1 or fragment 1.2. Much higher fragment concentrations were required for $50 \%$ inhibition of a prothrombinase complex consisting of Factor $\mathrm{Xa}$, Factor $\mathrm{Va}, \mathrm{Ca}^{2+}$ and phospholipid. This shows that Factor Va protects prothrambin activation agalnst inhibition by its own activation peptides. Less Inhibition by activation fragments was also observed at higher phospholfpid and prothrombin concentrations or when the mole fraction phosphetidylserine in the phospholipid vesicles was decreased. The effects of fragment 1 and fragment 1.2 on prothrombin activation were identlcal throughout al1 experiments, Indicating that the inhibition 1 due to the $p$-carboxyglutamic acid contalining region of the activation peptides. Our observations suggest that the activation fragments inhibit prothrombin activation by competing with prothrombin and Factor Xa for binding sites at the phospholipid surface. In such a model Factor Va will protect against the inhibition, since it is known to promote the assembly of the prothrombinase complex through interactions with Factor Xa and prothrombin that are Independent of the Gla residues. The kinetlc properties of fragment inhlbition also suggest that in vivo prothrombin activation w11 not be affected by the generation of activation peptides. 
INTRODUCTION

The activation of the zymogen prothrombin lato thrombin is one of the central reactions in blood coagulation. In vivo prothrombln activation is catalyzed by prothrombinase, a complex which consists of the serine protease Factor Xa and the non-enzymatic cofactors phosphollpld, $\mathrm{Ca}^{2+}$ and Factor Va (1). Factor Xa lis capable of hydrolyzlng two peptide bonds in the prothrombin molecule. The cleavage of the $\mathrm{Arg}_{274}-\operatorname{Thr}_{275}$ and $\mathrm{Arg}_{323}-\mathrm{Ile}_{324}$ bonds in bovine prothrombln by Factor Xa leads to the formation of thrombin and the activation peptide fragment 1.2 (2). The reaction product thrombin can cleave the Arg $156^{-\operatorname{Ser}_{157}}$ bond of both prothrombin and fragment 1.2, giving rise to fragment 1 and prethrombin 1 or fragment 2, respectively $(2,3)$. In recent years, much has been learned about the function of the nom-enzymatic cofactors in Factor Xa-catalyzed prothrombin activation. The stimulatory effect of phospholipids is due to a lowering of the Kri for prothrombin (4), whereas the role of Factor Va In prothrombin activation appears to be threefold: a) the Vmax of prothrombin activation is increased 1000-fold by Factor Va $(4,5)$ b) the binding of Factor Xa to phospholipids $1 . s$ promoted by Factor Va $(5,6)$ and c) Factor Va lowers the Km for prothrombin for membranes whilch have a low affindty for prothrombin $(7,8)$.

Prothrombln and Factor $X a$ are vitamin $k$-dependent protelns, containing $p$-carboxyglutamic actd residues (9), which are involved $\mathbb{1 n}$ the $\mathrm{Ca}^{2+}$-mediated binding of these proteins to negatively charged phospholipld surfaces. All 1 -carboxyglutamic actd restdues of prothrombin reside in 1 ts fragment 1 reglon. Since both fragment 1 and fragment 1.2 may be formed during in vivo prothrombin actuation, $1 \mathrm{t}$ is posslble that the activation peptides can interfere with the Interactions of prothrombin with the prothrombinase complex, and hence Inhibit prothrombin activation. Indeed it has been stated in literature that fragment 1 can 1 nhibit the generation of thrombin from prothrombin in vivo $(10-12)$.

In this article we present a kinetic study of the effects of fragment 1 and 1 ragment 1.2 on prothrombin activation. Such a study not only provides Insight in a possible regulatory role of the activation peptides during in vivo prothrombin activation, but may also give mechanistic information regarding the trodes of action of phosphollpids and Factor Va in prothrombin activation. The precise mechanisms by which phosphollpids $(4,7,8)$ and 
Factor Va $(7,8)$ decrease the $\mathrm{Km}$ for prothrombin are not yet known. Since fragment 1 can compete with prothrombin for binding to phosphollpid vesicles and fragment 1.2 has the additional ablifty to interact with Factor Va through its fragment 2 region (12), a comparison of the effects of these fragments on prothrombin activation by Factor $X$, in the presence of various kinds of phospholipids, wh and without Factor Va, may Indicate which interactions are important for the lowering of the $\mathrm{Km}$ for prothrombin.

MATERIALS AND METHODS

Materials. S2238, $\$ 2337$ and 12581 were purchased from $A B$ Kabl Dilagnostica, Stockholm. Phe-Pro-Arg $-\mathrm{CH}_{2} \mathrm{Cl}$ and dansyl-Glu-Glu-Arg-CH ${ }_{2} \mathrm{CL}$ were obtained from Calbiochem. $P-N P G B$ was from ICN Nutritional Blochemicals. Dvalbumin, HSA (human serum albumin, fatty acid free), STI (soybean trypsin inhibitor), RWV (Russel1's viper venom), Echls carinatus venom and $\mathrm{PC}(1,2-\mathrm{d}$ oleoy1-sm-glycero-3-phosphocholine) were obtalned from Sigma. DEAE-Sephadex A-50, QAE-Sephadex A-50, SP-Sephadex C-50, Sephadex G-75, Sephadex G-100, Sephacry1 $S-300$ and CNBr-actlvated Sepharose 4B were supplied by Pharmacla. STI, Factor $X$, and antibovine Factor $X$ were coupled to GNB -activated Sepharose 4B according to the method of Cuatrecasas (13).

Phospholiplds and phospholipid vestcle preparations. PS $(1,2$-d loleoyl-singlycero-3-phosphoserine) was prepared from PC by enzymatic aynthesta as descrtbed by Comfurtus and $Z$ wal (14). Single bllayer phosphollpld vestcles were obtained by sonication according to the method of de kruiffe et al. (15). Phospholipid concentrations were determined by phosphate analysis according to Bottcher et al. (16).

Proteins. Bovine prothrombin was purified according to the method of owen et al (17). Thrombln was purifled as described earlier (4). Factor $X$ (18), Factor Xa (19), RVV-X (20) and Factor IXa (2l) were purifled according to established procedures. Factor $V$ and Factor Va were obtalned as described by Lindhout et al (6). Factor VIII:c was purffled by a modification of the method of Vehar and Davie (22), as publlshed elsewhere (23). Factor VIII:c 
was actyated with throwbin as described before (2l). Prothrombin fragment 1. fragment 2, and fragment 1.2 were purifled as prothrombin activation producti (ciof ref. 17) from a reaction mlxture contalning prothrombin ( 3 ag/mil) and Factor Xa $(50 \mu \mathrm{g} / \mathrm{ml})$ in $20 \mathrm{mM}$ Tris ( $\mathrm{pH} 7.5), 100 \mathrm{mM} \mathrm{NaCl}$, and 5 m $\mathrm{CaCl}_{2}$ at $37^{\circ} \mathrm{C}$. For the preparation of fragment 1.2 the prothrombin activation mixture contalned $200 \mu$ I 2581 , a reversible thrombin inhlbitor, that prevents feedback reactions of thrombin on prothrombin and fragtant 1.2. After $90 \mathrm{~min}$ STI-Sepharose $(0.25 \mathrm{~m} 1$ per ml reaction mixture) was added to bind Factor $x a$ and $10 \mathrm{~m} 1 \mathrm{n}$ later the STI-Sepharose was spun down. In order to 1 rreversibly 1 nhibit thrombin and the remaining Factor $X a$, Phe-Pro-Arg-CH $2 \mathrm{Cl}$ and dansy1-Glu-G1y-Arg-CH${ }_{2} \mathrm{Cl}$ were added to the supernatant (final concentrations $16 \mu$ and $1.5 \mu \mathrm{M}$, respectively). This mixture was applied to a QAE-Sephadex A-50 colum $(1.5 \times 30 \mathrm{~cm})$ and the prothrombin detivation products were eluted with a linear gradient $(2 \times 200 \mathrm{mil}$ ) of 0.1 to $0.6 \mathrm{MaCl}$ in $50 \mathrm{MP} \mathrm{Tr} s(\mathrm{pH} 7.5)$ and $5 \mathrm{mM}$ EDTA. Each activation fragment was subsequent1y aubjected to gel-permeation chromatography on sephadex G-75 in $50 \mathrm{mM}$ Tris ( $\mathrm{pH} 7.5)$ and $500 \mathrm{mM}$ NaCl. The activation fragment preparations were Elnally passed over an ant1-bovine Factor $X$ sepharose 4B column to remove traces of Factor Xa that still contaminated the fragment preparations.

Protein concentrations. The concentrations of thrombin, Factor $X a$ and Factor IXa were determined by active site titration with P-NPGB (24-26). prothrombin and Factor $X$ were completely activated with Echis carinatus venom and $R V-X$ respectively, and thelr concentrations were subsequently detemined by active slte titration wth p-NPGB. The concentration of Factor Va was determined by kinetlc analysis (6) and Factor VIII:c was quantitated as described before (27). The molar concentrations of fragment 1 and fragment 1.2 were calculated from the $\mathrm{E}_{280}$ using an $\mathrm{E}_{280}^{1 \%}$ of 10.1 and a molecular wetght of 22,500 for fragment 1 (28) and an $\mathbb{E}_{280}^{1 \%}$ of 12.3 and a molecular weight of 35,000 for fragment 1.2 (28).

Assay system for measurement of rates of prothrombin activation. Factor Xa and phosphollplds either in the absence or presence of fragment 1 , fragment 1.2 , and/or Factor Va were incubated for 5 min at $37{ }^{\circ} \mathrm{C}$ in a buffer contalning $50 \mathrm{mM} \operatorname{Trls}(\mathrm{pH} 7.9), 175 \mathrm{mM} \mathrm{NaCl}, 5 \mathrm{mM} \mathrm{CaCl} 2$, and 0.5 
mg/m1 HSA. Prothrombin activation was started by adding prewarmed prothrombin in the same buffer. The flnal proteln concentrations in the reaction ulxtures are Indicated in the legends to the flgures. Rates of prothrombin activation were determined with 52238 as described before (4).

Assay system for the measurement of rates of Factor X actlvation. Factor IXa and phospholipids, either in the absence or presence of fragment 1 , were lacubated for $5 \mathrm{~min}$ at $37{ }^{\circ} \mathrm{C}$ in a buffer containing $50 \mathrm{mM} \mathrm{Tr} / \mathrm{s}$ ( $\mathrm{pH}$ 7.9), $175 \mathrm{mM} \mathrm{NaCl}, 5 \mathrm{mM} \mathrm{CaCl} 2$, and $0.5 \mathrm{mg} / \mathrm{ml}$ HSA. Factor $\mathrm{X}$ actlvation was started by simultaneous addition of Factor VIIIa (if present) and Factor $X$, prewarmed in the same buffer. The final protein concentrations in the reaction mixtures are Indicated in the legends to the flgures. Rates of Factor X activation were determined with 52337 as described before (21).

\section{RESULTS}

Effect of fragment 1 and fragment 1.2 on prothrombin activation in the absence of phosphollplds. We first investigated whether the activation peptides fragment 1 and fragment 1.2 inhibit Factor Xa-catalyzed prothrombin activation in free solution. In an experiment, in which $1.2 \mu M$ prothrombin was activated by either $50 \mathrm{nM}$ Factor Xa or $0.2 \mathrm{nM}$ Factor Xa in the presence of $30 \mathrm{nM}$ Factor Va, we did not detect any inhibition of prothrombin activation at concentrations of fragment 1 or fragment 1.2 between 0 and $10 \mu \mathrm{M}$. The conversion of the chromogente substrate $\mathrm{S} 2337$ by Factor Xa was also not affected by fragment 1 and fragment 1.2 concentrations up to $10 \mu \mathrm{M}$. These findings indicate that the prothrombin activation fragments do not interact with prothrombin or Factor $X a$ in a manner by which they Interfere with the catalytic activity of Factor Xa on prothrombin per sé.

Effect of fragment 1 and fragment 1.2 on prothrombin activation in the presence of negatively charged phosphollpids. In contrast to the reaction In free solution, phospholipld-dependent prothrombin activation was inhibited by the activation fragments (Fig. 1). The Inhibition patterns differed considerably depending on whether Factor Wa was present or not. 


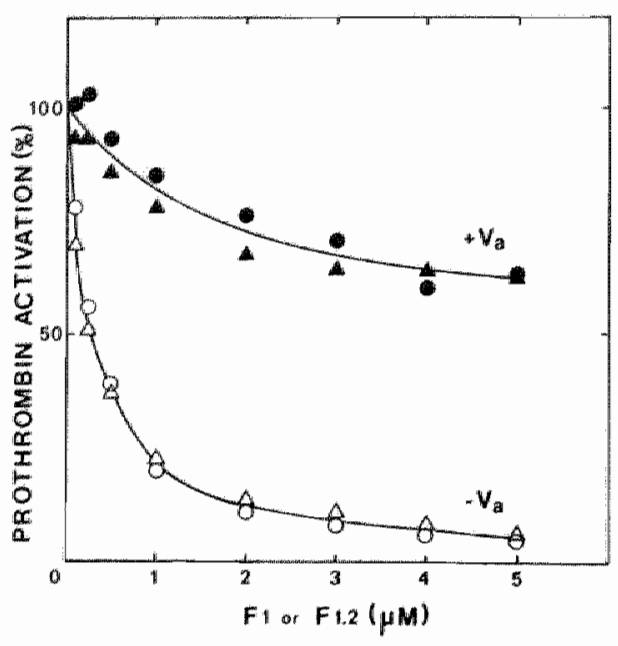

Fig. 1. Effect of fragment 1 and fragment 1.2 on prothrombin activation in the presence of phospho1iplds. Prothrombin activation was measured in reaction buffer containIng $50 \mu \mathrm{M}$ phospholipid vestcles (PS/PC, 25/75; mole/mole), $0.25 \mu \mathrm{M}$ prothrombin and $2 \mathrm{nM}$. Factor $\mathrm{Xa}$ (open symbols) or 1 pM Factor $\mathrm{Xa}$ and $5 \mathrm{nM}$ Factor Va (closed symbols). The concentration of fragment $1(\mathrm{O}-\mathrm{O},-0)$ or fragment $1.2(\Delta-\Delta, \Delta-\Delta)$ present are indicated in the figure. Rates of prothrombin activation are expressed relative to the rate measured in the absence of activation Eragments which was taken as $100 \%$. W1thout Factor Va $100 \%=2.07$ moles prothrombin activated/min/mo1 Xa and wth Factor Va $100 \%=3093$ moles prothrombin activated/min/mol $\mathrm{Xa}$.

The activation of $0.25 \mu \mathrm{M}$ prothrombin by Factor Xa in the presence of $50 \mu \mathrm{M}$ phosphollpld vesicles was strongly inhlbited by both fragment 1 and fragment 1.2. The inhibition characterlstics of fragment 1 and fragment 1.2 did not differ and both activation fragments caused $50 \%$ intulition at a concentration of $0.28 \mu \mathrm{M}$. Much less inhtbition was observed when saturating amounts of Factor Va are Included in the reaction mixtures. Although both activation fragments gave the same inhlbltion pattern, fragment concentratlons exceeding $5 \mu \mathrm{M}$ had to be added to obtain 50\% Inhibition. The protective effect of Factor Va was not only found in this experiment but is a general feature observed in all experiments in which Factor va was present.

Fragment 2, the prothrombin activation peptlde which lacks Gla residues, but which has retalned the ability to interact with Factor Va (12), did not InhLbtt prothrombin activation, irrespective of whether phospholipid and/or Factor Va were present or not. In the present study this activation peptide was therefore not further examined.

Effect of the phosphollpid concentration on the inhlbition of prothrombin activation by fragment 1 and fragment 1.2 . Since the experiments presented in the prevlous paragraphs indicate that inhibition of prothrombin activation by fragment 1 and fragment 1.2 only occurs in the presence of phosphollpid, we decided to investigate whether the extent of Inhibition 

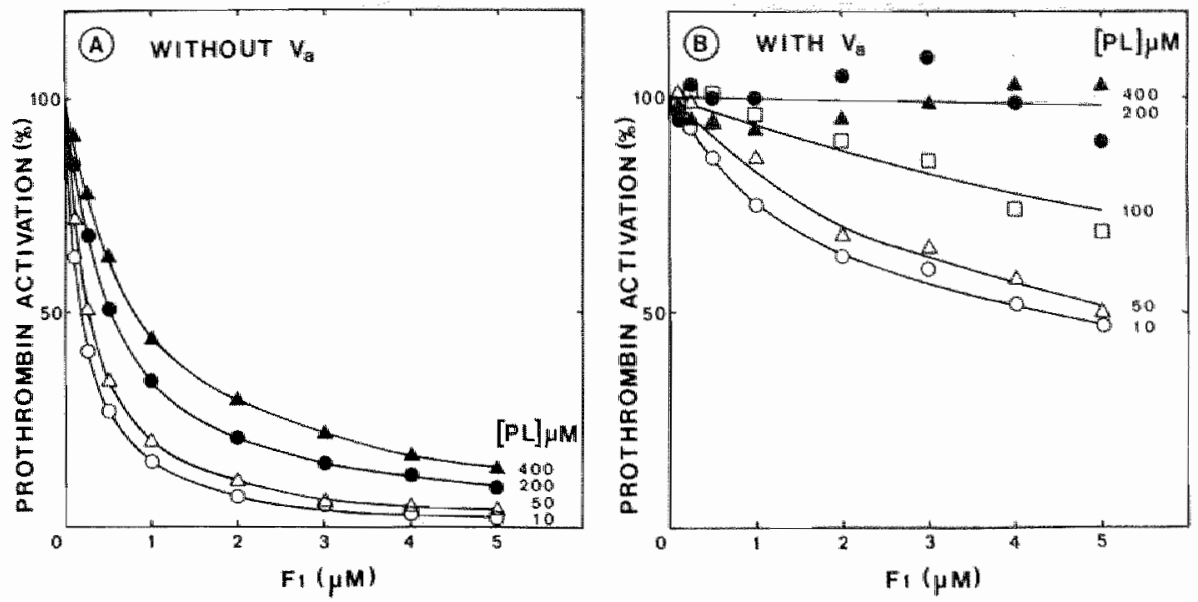

Fig. 2. Inhibition of prothrombin activation by fragment 1 at different phospholipid concentrations. Prothrombin activation was measured in reaction buffer containing $0.25 \mu \mathrm{M}$ prothrombin, amounts of fragment 1 Indicated in the figure and 2 nM Factor Xa (Fig. 2A) or 1 pM Factor $\mathrm{Xa}$ and 5 nM Factor Va (FIg. 2B). The amounts of phosphollpid vesicles ( $P S / P C, 25 / 75$; mole/mole) present were $10 \mu \mathrm{M}(0-0), 50 \mu \mathrm{M}$ $(\Delta-\Delta), 100 \mu \mathrm{M}(\square-\square), 200 \mu \mathrm{M}(\mathbf{0}-\boldsymbol{)})$, or $400 \mu \mathrm{M}(\boldsymbol{\Delta}-\boldsymbol{\Delta})$. Rates of prothrombin activation are expressed relative to the rate measured in the absence of fragment 1 , which was taken as $100 \%$. Without Factor $\mathrm{Va}$ (A) $100 \%$ was $1.15(0-0), 1.67(\Delta-\Delta), 0.93(-0)$, or $0.64(\Delta-\Delta)$ moles prothrombin activated $/ \mathrm{m} / \mathrm{n} / \mathrm{mol}$ Xa. With Factor Va. (B) $100 \%$ was $2332(\mathrm{O}-\mathrm{O}), 2664(\Delta-\Delta), 1314(\square-\square), 809(\mathbf{0})$, or $522(\boldsymbol{\Lambda}-\mathbf{\Delta})$ moles prothrombin act 1 vated/min/mol Xa.

depends on the amount of phospholipid present in the reaction mixture. In Fig. 2 it is show that inhibition of prothrombin activation by fragment 1 was less promounced at higher phosphollpid concentrations. This phenomenon was observed both in the absence (FIg. 2A) and presence of Factor Va (FIg. $2 B$ ). For the complete prothrombin actlvating complex (Factor $\mathrm{Xa}, \mathrm{Va}, \mathrm{Ca}^{2+}$ and phosphollpld) it was even impossible to detect any inhibition by fragment 1 t phospholipid concentrations of 200 uM or higher. Fragment 1.2 showed the same inhtbition characteristics (data not shown) and could not be distingulshed from fragment 1.

Inhibition of prothrombin activation by fragment 1 and fragment 1.2 in the presence of phospholipid vesicles containing vartous mol \% PS.

The phospholipld vesicles used in the previous experiments contalned 25 mol\% PS. These vesicles are reported to have a high affinity for prothromin and 

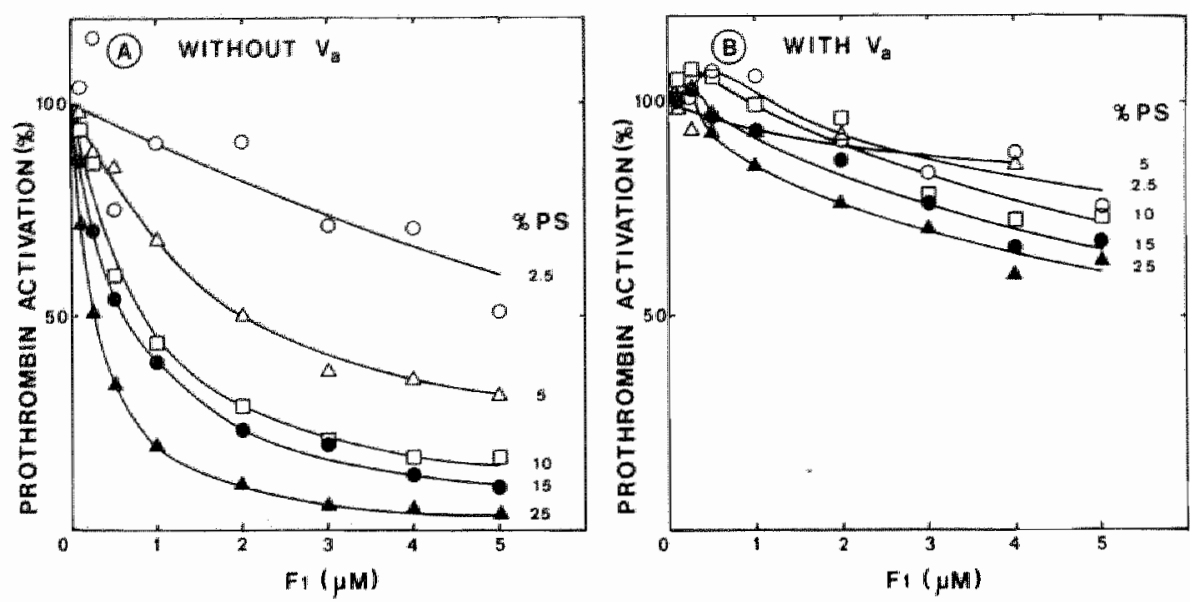

F1g. 3. Inhtbition of prothrombin activation by fragment 1 measured in the presence of phospholip1d vesicles with varying wo1 $X$ PS. Prothrombin activation mas measured in reaction buffer contalning $50 \mu \mathrm{M}$ phospholip1d, $0.25 \mu \mathrm{M}$ prothrombin, amounts of fragment 1 indicated In the figure, and 2 nM Factor Xa (F1g. 3A), or $1 \mathrm{pM} F a c t o r$ Xa and $5 \mathrm{nM}$ Factor Va (FIg. 3B). The phospholipid vesicles contained the following mol \% PS (supplemented to $100 \%$ with PC): $2.5 \%$ PS (O-O) 5\% PS $(\Delta-\Delta), 10 \%$ PS $(\square-\square), 15 \%$ PS $(\boldsymbol{\bullet}-\boldsymbol{\bullet}), 25 \%$ PS $(\boldsymbol{\Delta}-\boldsymbol{\Delta})$. The rates of prothrombin activation are expressed relative to the rate measured in the absence of fragment 1 which was taken as $100 \%$. Without Factor Va (A) $100 \%$ was $0.0084(O-O), 0.047(\Delta-\Delta), 0.227(\square-\square)$, $0.511(--)$ or $1.98(\Delta-\Delta)$ moles prothrombin activated $/ \mathrm{min} / \mathrm{mol} \mathrm{Xa}$. With Factor Va (B) $100 \%$ was $1840(0-0), 3360(\Delta-\Delta), 2796(\square-\square)$, $2971(-0)$ or $3170(\Delta-\Delta)$ moles prothrombin activated/min/mol Xa .

Factor Xa $(29,30)$. Although no blnding affinities are reported for fragment 1 or fragment 1.2 it 1 s likely that they are simllar to those for prothrombin. The affintey of vitamin $\mathrm{K}$-dependent coagulation factors for phospho11 id bllayers decreases when the mol fraction of negatively charged phospholiptd is decreased $(29,30)$. Fig. 3 shows the effect of vartation of the mol \% PS in phospholipid vesicles on the inhibition of prothrombin activation by fragment 1 . The most striking effect was observed again in the absence of Factor Va (FIg. 3A). Fragment 1 was an excellent inhlbitor of prothrombin activation at vestcles containing a high mol $\%$ PS. When the mol $\%$ PS 1 the phospholipid vesicles was decreased from 25 to $2.5 \%$, there was a considerable decrease of the potency of fragment 1 to inhibit prothrombin activation. Fifty percent inhibition was observed at $0.28 \mu \mathrm{M}$ fragment 1 for vestcles containing 25 mo 1 \% PS whereas for vesicles con- 


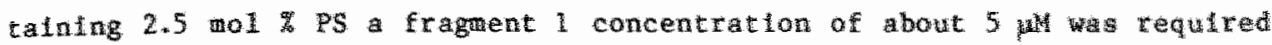
to obtaln the same level of inhibltion. It should be emphasized that the rate of prothrombin activation for each lndividul kind of phosphollpla are expressed relative to that measured in the absence of rraguent 1 . of course the rates of prothrombln activat lon at low mol $\%$ pS were apprectably lower than those determined at high wol $\mathrm{*s}$ (cf. ref. 8).

In the presence of Factor Va the effect of varlation of the mol ${ }^{2}$ IS on the inhibition of prothrombln by fragment 1 was much less pronounced (FIg. 38). Frothromin activation by Factor Xa-Va in the presence of vestcles wth a high $\mathrm{PS}$ content was already poorly lnhiblted and a decrease of the anount of PS in the phospholipid memrane caused a further decrease of inhibltory effect of fragment 1. In some cases we even observed some atturiation of prothromin activation at low fragment 1 concentratons. In the discussion we w11 give a posstble explanation for this staulatory effect. The expertment presented in Fig. 3 was repeated wh fragment 1.2 . This activation peptlde showed the same inhbition pattern as was observed for fragment 1 (data not shown).

Effect of fragment 1 and fragment 1.2 on prothrombin actlyation at different prothrombin cancentrations. The kinetic properties of the prothrombinase coaplex are atisfactorlly explafned In a model in which phosphollpld-bound prothrombin is activated by phosphollpld-bound Factor Xa $(4,8,31,32)$. In this paper we observe that inhibition of prothrombin activation by fragment 1 and fragment 1.2 only occurs in the presence of phospholipid and that the inhibition ls less at higher phospholipid concentrations and at vesicles with a low binding affinlty for the activation fragments. Therefore, it $1 \mathrm{~s} 1 \mathrm{lkely}$ that fragment 1 and fragment 1.2 inter fere with prothrombin activation via interaction with the phospholipld surface. Binding of fragment 1 and fragment 1.2 to phospholipld will lower the number of surface-binding sites for prothrombin and/or Factor Xa which will result in an inhibition of prothrombin activation. The Inhibition will than have a competitive character, since 1 t originates through competition of the activation fragments. Wth prothrombin and/or Factor Xa for blinding sites at the phospholipid surface. In that case, inhibition by activation fragments will be less at higher prothrombin (substrate) concentrations. Indeed it was found that increased prothrombin concentrations protect 

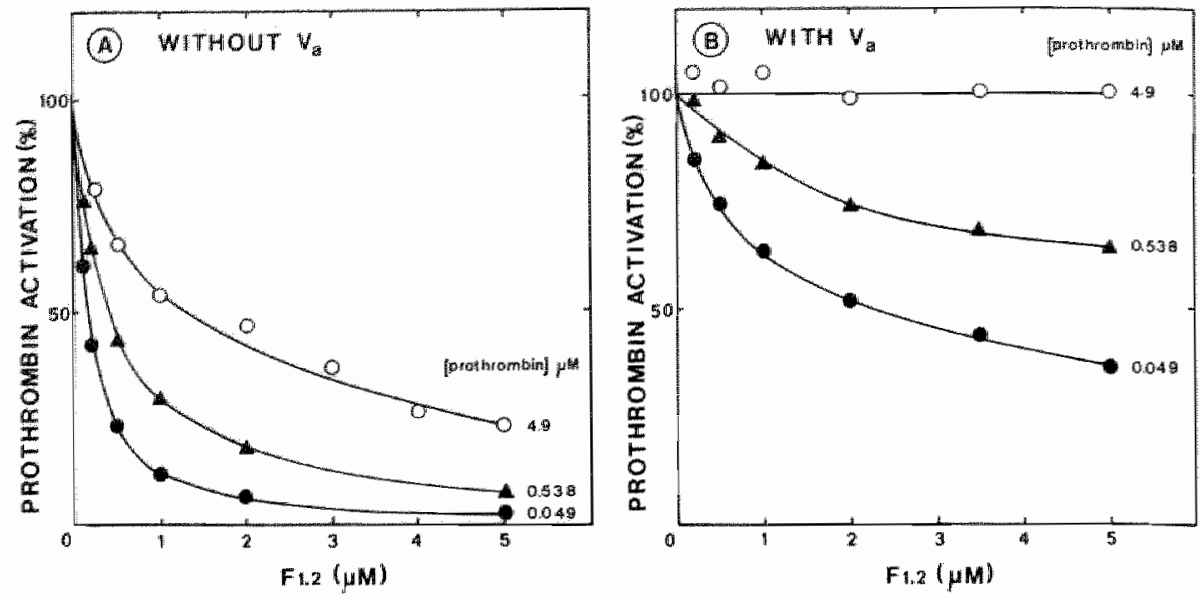

Fig. 4. Inhibition of prothrombin activation by fragment 1.2 measured at different prothrombin concentrations. Prothrombin activation was measured in reaction buffer contalning $50 \mu \mathrm{M}$ phospholipld, (PS/PC, 25/75; mole/mole), amounts of fragment 1.2 Indicated in the figure and $2 \mathrm{nM}$ Factor Xa (F1g. 4A), or $1 \mathrm{pM}$ Factor Xa and $5 \mathrm{nM}$ Factor Va $(\mathrm{F} 1 \mathrm{~g}, 4 \mathrm{~B})$. The reaction mixtures further contained $0.049 \mu \mathrm{M}(-\infty)$, $0.538 \mu \mathrm{M}(\boldsymbol{\Delta}-\mathbf{\Delta})$, or $4.9 \mu \mathrm{M}(\mathrm{O}-\mathrm{O})$ prothrombln. The rates of prothrombin activation are expressed relative to the rate measured in the absence of fragment 1.2 which was taken as $100 \%$. Without Factor Va (A) $100 \%$ was $0.68(\boldsymbol{0}-\boldsymbol{0}), 1.98(\mathbf{\Delta - \Delta})$, or $2.46(0-0)$ moles prothrombin activated/min/mo1 Xa. With Factor Va (B) $100 \%$ was 1111 (e-0), $3052(\boldsymbol{\Delta}-\boldsymbol{\Delta})$, or $3081(\mathrm{O}-0)$ moles prathrombln activated $/ \mathrm{m} / \mathrm{n} / \mathrm{mol} \mathrm{Xa}$.

against the inhlbition by fragment 1.2 (F1g. 4). In the absence of Factor $\mathrm{Va}$, a 10-fold higher fragment 1.2 concentration was requited to obtain $50 \%$ Inhlbition when the prothrombin concentration was ralsed from $0.049 \mu \mathrm{H}$ to 4.9 $\mu \mathrm{M}(\mathrm{FIg}$. 4A). A simflar protective effect of prothrombln was obserwed in the presence of Factor Va (FIg. 4B). Under these conditions the Inhibttion of prothrombin activation by fragment 1.2 could even be completely abolitshed at hlgh prothrombin concentrations.

Kinetic characterliation of the type of inhibltion of prothrombin actlyation by fragment 1 and fragment 1.2. Further 1 insight in the type of inhtbltion of enzymatic reactions can be obtalned from Lineweaver-Burk plots made at varlous concentrations of inhibltor. Fig. 5 shows the result of such an approach for the inhibition of prothrombin activation by fragment 1. In the absence of Factor Va, Lineweaver-Burk plots were made at 

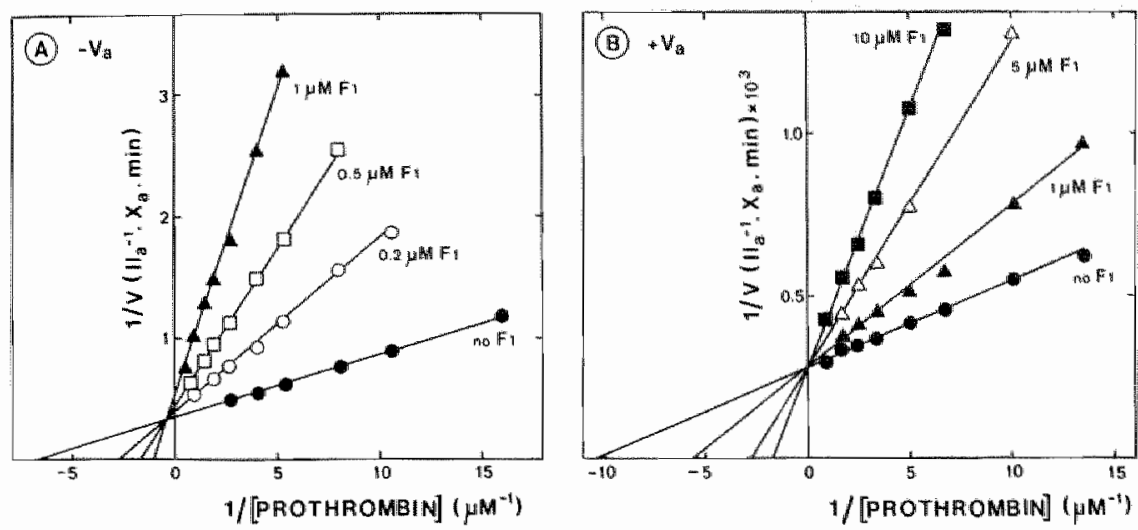

Fig. 5. Lineweaver-Burk plots of prothrombin activation measured in the presence of different concentrations fragment 1. Prothrombin activation was measured in reaction buffer contalning $50 \mu \mathrm{M}$ phosphollpid (PS/PC, 25/75; mole/mole), varying concentrations prothrombin, $0 \mu \mathrm{M}(\mathbf{0}-\boldsymbol{\theta}), 0.2 \mu \mathrm{M}(\mathrm{O}-\mathrm{O}), 0.5 \mu \mathrm{M}(\square-\square), 1 \mu \mathrm{M}(\mathbf{\Delta}-\mathbf{\Delta})$, or $5 \mu \mathrm{M}(\Delta-\Delta)$ fragment 1 , and $2 \mathrm{nM}$ Factor $\mathrm{Xa}(\mathrm{FLg} .5 \mathrm{~A})$, or 1 pM Factor $X a$ and 5 nM Factor Va (Fig. 5B). Lineweaver-Burk plots were drawn after statistical analysts as described by Elsenthal and Cornish-Bowden (33).

$0,0.2,0.5$ and $1.0 \mu \mathrm{M}$ fragment 1 (F1g. 5A). It $1 \mathrm{~s}$ obvious that the Inhtbition was not of a single type since upon variation of the fragment 1 concentration both the $\mathrm{Km}$ and the Vmax changed. It is possible that the Increase of the $\mathrm{Km}$ is caused by a competition of fragment 1 wth prothrombin whereas the decrease of the Vmax at higher fragment concentrations reflects competition with Factor Xa for binding stes at the phospholipld surface. In the presence of Factor Va higher concentrations of fragment 1 were required to obtain an effect on the Km for prothrombin ( 1 Ig. 5B). This Is presumably caused by the fact that Factor Va protects the prothrombinase complex against inhibition by the activation fragments. Factor va also abolished the effect of activation fragments on the Vmax. Th1s supports the concept that the decrease of the Vmax by activation fragments is due to competition with Factor Xa for surface-binding sites, since it is well established that Factor Va promotes the binding of Factor Xa to negatively charged phosphollplds $(5,6)$. It should be mentioned, however, that In the presence of Factor Va and fragment 1 an upward curvature of Lineweaver-Burk. plots was observed at low prothrombin concentrations $(<0.06 \mu \mathrm{M}$, data not 
ahown). Thl Indlcates that care should be taken in interpretation of the kinetlc data. In the absence of Factor Wa, Lineweaver-Burk plots were atralght lines over a lde range of prothrombin concentrations $(0.03-2 \mu \mathrm{M})$.

Effect fragment 1 on intrinsic Factor $x$ activation. When the inhibition of prothrombin activation by the Gla-containing activation fragments 1 and 1.2 is due to a competition wth prothrombin and/or Factor Xa for blinding sltes at the phospholipld surface, one would expect that both activation fragments would also inhibit intrinsic Ractor $X$ activation.

Like prothrombin activation this reaction also takes place at a negatively charged phosphollpdd surface (21). Indeed, we observed that Factor $X$ activation by Factor $I X a$ in the presence of phospholipid could be Inhiblted by fragment 1 (FIg * 6), although a high concentration ( 5 uM) was required to obtain 50\% 1nhibition. Factor VIIIa protects agalnst the Inhibition by fragment 1. In the presence of this cofactor there was hardly any inhibition. At low fragment 1 concentrations there was even a stimulation of Factor $X$ activation.

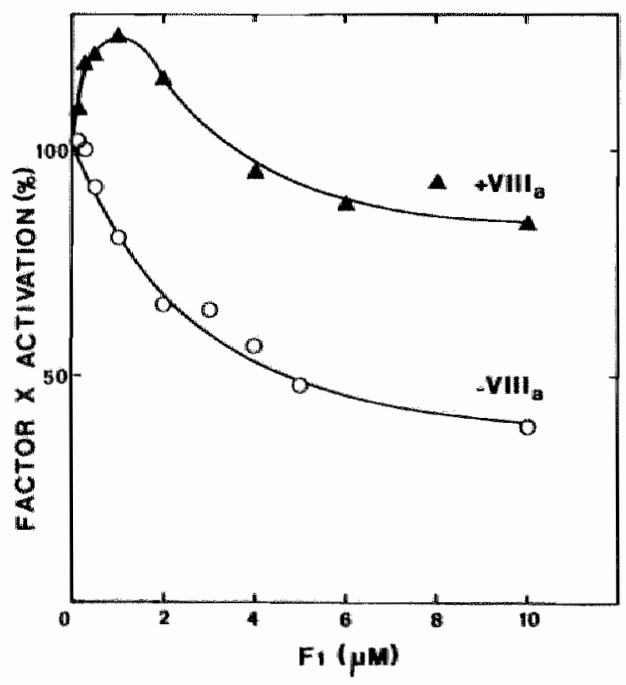

Fig. 6. Inhtbition of intrinsic Factor $X$ activation by fragment 1 . Intrinsic Factor $X$ actiration was measured in reaction buffer containing $50 \mu \mathrm{M}$ phosphol1pid (PS/PC, 25/75; mole/mole), $0.25 \mu \mathrm{M}$ Factor $X$, amounts of fragment 1 indicated in the flgure, and $96 \mathrm{nM}$ Factor IXa $(0-0)$, or $25 \mathrm{nM}$ Factor IXa and 0.02 nM Factor VIIIa $(\boldsymbol{\Delta}-\mathbf{\Delta})$, Rates of Factor $X$ activation are expressed relative to the rate measured in the absence of fragment 1 which is taken as 100\%. W1thout Factor VIIIa 100\% $1 \mathrm{~s} 0.444 \mathrm{nM}$ Xa formed/mln and with Factor VIIIa $100 \%$ is 5.25 nM Xa formed/min.

DISCUSSION

The data presented in this article demonstrate that the Gla-containing activation peptides prothrombin fragment 1 and prothrombin fragment 1.2 can 
Inlibit Factor Xa-catalyzed prothrombin activation in vitro. Since inhibition only occurs when negatively charged phospholiplds are part of the prothrombloracivating complex, it is likely that the activation fragments interfere with prothrombin activation through an interaction with the phospholipid surface. It is now well established that prothrombin activation in the presence of phospholiplds is a surface process in which phosphollpid-bound prothrombin is activated by phospholipid-bound Factor Xa $(4,7,8,30,31)$. The precise mode of action of phospholipids differs, however, dependent on whether Factor Va 1 s present or not $(7,8)$. In the absence of Factor $\mathrm{Va}$, the prothrombin that is converted by phosphollpldm bound Factor Xa can originate from a dense shell of bound prothrombin that surrounds the phospholipid membrane $(4,8,32)$, whereas in the presence of Factor Va the formation of the prothrombin-prothrombinase complex is the result of multiple interactions of soluble prothrombin with Factor Xa, Factor Va and phospholiplds $(7,8,31)$. In both situations occupation of binding stes at the phospholipid surface by activation fragments w11 interfere with the interaction of prothrombin and Factor Xa with phospholipid resulting in a decrease of the rate of prothrombin activation. The possibility for different modes of action of phospholipid in the absence and presence of Factor $\mathrm{Va}$ is also supported by the experiments presented in this paper. In the absence of Factor Va both fragment 1 and fragment 1.2 are excellent inhibitors of prothrombin activation, whereas much less Inhibition is observed in the presence of Factor Va.

The strong inhibition by activation fragments in the absence of Factor va 1s explained in a model in which the fragments compete with prothrombin and Factor Xa for binding stes at the phospholipid surface. Competition with prothrombin w11 lower the effective substrate concentration avallable for reaction th Factor $X a$ and competition with Factor $X a$ will lower the amount of phospholipid-bound enzyme that particlpates in prothrombin activation. The Inhibition has competitive characteristics since less inhtbition 1 s observed at higher prothrombin concentrations. A reduction of the extent of Inhibition was also found at higher phosphollpid concentrations, or when phospholipids with lower PS content were utilized in the prothrombinase complex. In a "competitive model" more activation fragments wil be required at higher phosphollpid concentrations, since a larger number of binding sites has to be occupled, in order to effectively reduce 
the concentrations of phospholipld-bound prothrombln and Factor Xa. At phosphollpld vestcles wh a low porcentage PS, efflcient occupation of binding ates all also require more activation fragment since such veslcles are known to have a low affinity for vitamin $K$-dependent coagulation factors $(29,30)$.

The type of inhibltion of prothrombin activation by fragment 1 and fraginent 1.2 is not purely competitive, since Lineweaver-Burk plots show that upon an tncrease of the actiwation fragment concentration the $\mathrm{Km}$ for prothrombin increases and the Vmax of prothrombin activation decreases. This is not surprising since pure competitive inhibition requires competition between lnhibitor and substrate for binding to the active site of Factor Xa which $1 \mathrm{~s}$ apparently not the case in our experiments. We belleve that the Increase of the $\mathrm{Km}$ results from the competition of activation fragment with prothrombin binding to phospholiplds and that the decrease of the Vmax is caused by a competition with Factor Xa for phospholtpid.

Factor Wa protects the prothrombinase complex against inhibition by activation fragments. In the presence of Factor $\mathrm{Va}$, almost no inhibition was observed at high phosphollpld or prothrombin concentrations, or when prothrombin activation was measured in the presence of phospholipld vesicles with low mol \% PS. The protective effect of Factor Va may reflect its role in the assembly of the prothrombinase complex. Factor Va is reported to enhance the binding of Factor Xa to negatively charged phospholfplds $(5,6)$ and to promote the interaction of prothrombin with the ensymatic untt of the prothrombinase complex $(8,31)$. These interactions are presumably independent of the p-carboxyglutamic acid residues of prothrombin and hence not llable to incerference by activation fragments. Such Gl- Independent interactions may also be Involved in the assembly of the Intrinslc Factor $X-a c t$ lvating complex and can provlde the explanation for the fact that Factor VIIa protects this complex against inhibltion by prothrombin activation fragments *

In an earlier paper ( 8 ), we presented kinetic evidence In support of the proposal of Nelsestuen. (31) that the low $\mathrm{Km}$ for prothrombin of prothrombinase in the presence of Factor Va ts the result of prothrombin-Factor $\mathrm{Va}$ and prothrombin-phospholipid interactions that occur near the active site of prothrombinase. Binding of prothrombin to phospholipid outside the 
enzyatic domaln is actually unfavourable since it lower the fective prothrombin concentration avallable for interaction with the entratic unit. This may explain why in certain experiments a stimulation of prothrombin activation was observed at low activation fragment concentrations (Fig. 2B and Fig. 3B). The action of the activation fragments can be twofold. They can stimulate prothrombin activation by increasing the effective prothrombin concentration through removal of prothrombin from the excess of phospholipld binding sites, whereas they inhdbit prothrombin activation by competition for phospholiplds that particlpate in the interactions at the enzymatic unit. It is posslble that under some conditions the stimulatory effect of activation fragments exceeds their Inhibitory effect. A simflar explanation can be glven for the stimulation of intrinsic Factor $X$ activation in the presence of Factor VIIIa (F1g*6).

The data presented in this paper also contaln information regarding the way by whlch Factor $V a$ increases the affinity of prothrombin for a prothrombinase complex that contains phospholiplds with a low affintty for vitam in $\mathrm{k}$-dependent coagulation Factors $(7,8)$. This can be accomplished by a) a direct Interaction of prothrombin with factor $\mathrm{Va}(8,31)$, probably through its fragment 2 region, or b) a Factor Va induced clustering of negatively charged phosphollpid molecules around the enzymatic unit that creates a better surface for prothrombin binding ( 8 ), or c) (not mentioned before) a Factor Va induced increase of a rate constant in the pathway of prothrombin activation that simultaneously increases the $k_{\text {cat }}$ and decreases the $\mathrm{Km}$. In a simplified reaction scheme for serine proteases

$$
\mathrm{E}+\mathrm{S} \stackrel{\mathrm{ks}}{=} \mathrm{ES} \underset{\mathrm{P}_{1}}{\mathrm{k2}} \mathrm{EA}-\frac{\mathrm{k} 3}{\mathrm{E}}+\mathrm{A}
$$

$k_{\text {cat }}=\frac{k 2 \cdot k 3}{k 2+k 3}$ and $k m=k s \cdot \frac{k 3}{k 2+k 3}$

In such a mechanism, it is possible that an increase of a single rate constant ( $k 2$ ) by Factor Va can cause an increase of $k_{\text {cat }}$ and a decrease of the $\mathrm{Km}$. Using fragment 1 inhibition paterns as a tool to distingulsh between these possibilities one would expect that: 
1. fragment 1.2 1 a better inhibitor than fragment 1 in case of prothrombin actlyation in the presence of Factor Va and low affinity phospholiptds th posslblity a

2. fragment 1 and fragment 1.2 are excellent Inhibltors of prothrombinase in the presence of Factor $V a$ and low affinity phospholipid in pose1bu1ty b

3. both fragment 1 and fragment 1.2 are poor inh1bitors in possiblity $c$, since Factor Va exerts 4 ts effect on the $\mathrm{km}$ for prothrombin via an increase of a rate constant which w11 likely not be affected by either act Ivation fragment.

The experiments presented in this paper netther support possibility a) nor b) and are on basis of exclusion in favour of possibllity c). We are of course aware of the fact that this reasoning is more or less speculative, since $1 \mathrm{t} 1 \mathrm{~s}$ assumed that the 1 solated activation fragments have retalned ful1 capacity to Interact with phospholipids (fragment 1 and fragment 1.2) or Factor Va (fragment 1.2), whlch may not be the case. It emphasizes however, that possibllity c) has to be taken into account in future consider ations on the mechanism of action of Factor Va in prothrombin activation.

It has been reported that there is no signiflcant fragment 1 formation durling prothrombin activation in blood and plasma (34). The major activation peptide demonstrated in serum was fragment 1.2 . It is unlikely that fragment 1.2 plays a regulatory role during in vivo prothrombin activation. In vivo prothrombin activation occurs at approximately $2 \mu M$ prothrombin in the presence of Factor Va at a membrane surface that 11 kely contalns a low dens 1 ty of negatively charged phospholiplds (35). Dur data lndlcate that under these conditions the activation fragments hardly affect prothrombin activation.

REFERENCES

1. Suttle, J.W. and Jackson, C.M. (1977) Physiol. Rev. 57, 1-70.

2. Stenn, K.S. and Blout, E.R. (1972) Biochemistry, 11, 4502-4515.

3. Esmon, C.T., Owen, W.G. and Jackson, C.M. (1974) J. B10l. Chem. 249, $606-611$.

4. Rosing, J., Tans, G., Govers-Rlemslag, J.W.P., Zwaal, R.F.A. and Hemker, H.C. (1980) J. B101. Chem. 255, 274-283. 
5. Neshe1m, M.E., Taswell, J.B. and Mann, K.G. (1979) J. Blol. Chem. 254, $10952-10962$.

6. Lindhout, T., Goverg-Riemslag, J.W.P., van de Hart, P., Hemker, H.C. and Rosing, J. (1982) Blochemistry 21,5494-5502.

7. Pusey, M.L. and Nelsestuen, G.L. (1983) Blochem. Blophys. Res. Comm. $114,526-532$.

8. van Rijn, J.L.M.L., Govers-Riemslag, J.W.P., Zwal, R.F.A. and Rosing, J. (1984) Btochemistry 23, 4557-4564.

9. Stenflo, J., Fernlund, P., Egan, W. and Roepstorff, P. (1974) Proc. Nat. Acad. Sc1. 71, 2730-2733.

10. Jesty, J. and Esnouf, M.P. (1973) Blochem. J. 131, 791-799.

11. Benson, B.J., Kistel, W. and Hanahan, D.J. (1973) Blochim. Blophys. Acta $329,81-87$.

1.2. Seegers, W.H., Nowoa, E., Nalz, D.A., Andary, T.J. and Hassouna, H.I. (1976) Thromb. Res. 8, 83-97.

13. Cuatrecasas, P. (1970) J. B10.1. Chen. 245, 3059-3065.

14. Comfurius, P. and Zwaal, R.F.A. (1977) Blochim. Blophys. Acta 488, $36-42$.

15. De Kruljff, B., Cul1is, P.R. and Radda, G.K. (1975) Blochim. Blophys. Acta $406,6-20$.

16. Bottcher, G.J.F., Van Gent, C.M. and Prles, C. (1961) Anal. C1In. Acta $24,203-207$.

17. Owen, W.G., Esmon, C.T. and Jackson, C.M. (1974) J. Biol. Chem. 249, $594-605$.

18. Fuflkawa, K., Legaz, M.E. and Dav1e, E.W. (1972) Biochem1stry 11, 4882-4891.

19. Fuflkawa, K., Legaz, M.E. and Davle, E.W. (1972) Biochem1stry 11, 4892-4899.

20. Schiffman, S., Theodor, J. and Rapaport, S.J. (1969) Biochemistry 8, 1397-1405.

21. Van DiefJen, G., Tans, G., Rosing, J. and Hemker, H.C. (1981) J. B101. Chen. $256,3433-3442$.

22. Vehar, G. and Davle, E.W. (1980) Blochemistry 19, 401-410.

23. van Rijn, J., Rosing, J. and van Diefjen, G. (1983) Eur. J. Blochem. $133,1-10$.

24. Chase, T. Jr. and Shaw, E. (1969) Btochemtstry 8, 2212-2224.

25. Sm1th, R.L. (1973) J. B1o1. Chem. 248, 2418-2423.

26. Tans, G., Janssen-Claessen, T., van DLe1jen, G., Hemker, H.C. and Rosing, J. (1982) Thromb. Haemost. 48, 127-132.

27. van Dielfen, G., Rosing, J., Bevers, E.M., Hemker, H.C. and Zwaal, $R . F * A . \quad(1982)$ in Current toples in haemofilia. (R.T. Wensley ed.) Manchester, NDT prints, Brunswick M111 pp. 3-14.

28. Esmon, C.T. and Jackson, C.M. (1974) J. B1o1. Chem. 249, 7782-7790.

29. Nelsestuen, G.L. and Broderius, M. (1977) Biochemistry 16, 4172-4177.

30. van Diefjen, G., Tans, G., van Rifn, J.L.M.L., Zwaal, R.F.A. and Rosing, J. (1981) Blochemistry 20,7096-7101.

31. Nelsestuen, G.L. (1978) Fed. Proc. 37, 2621-2625.

32. Nesheim, M.E., E11d, S. and Mann, K.G. (1.981) J. B101. Chem. 256, $9874-9882$.

33. Ef senthal, R. and Cornish-Bowden, A. (1974) Blochem. J. 139, 715-720.

34. Aronson, D.L., Stevan, L., Bal1, A.P., Franza, B.R. Jr. and Flnlayson, J.S. (1977) J. C1in. Invest. $60,1410-1418$.

35. Bevers, E.M., Comfurius, P., van Rijn, J.L.M.L., Hemker, H.C. and Zwal, R.F.A. (1982) Eur. J. Biochem. 122, 429-436. 
* 
CHAPTER III

\begin{abstract}
PROTHROMBIN ACTIVATION BY AN ACTIVATOR FROM. THE VENOM OF OXYURANUS SCUTELLATUS (TAIPAN SNAKE)
\end{abstract}

\title{
SUMMARY
}

The prothrombin activator from the venom of oxyuranus scutellatus (Talpan snake) was purifled by gel filtration on sephadex G-200 and lon-exchange chromatography on QAE-Sephadex. The activator is a large protelin with a molecular welight of approximately 300,000 , which is composed of subunits of $M_{r} 110,000$ and 80,000 and two disulfide-ilnked polypeptides of $M_{r}{ }^{30,000}$. One or both of these $M_{r} 30,000$ subuntts contaln the active site. The venom activator readily converts Factor Xa-spectflc chromogenic substrates and is also able to activate prothrombin $(\mathrm{Km}=166 \mu \mathrm{M}, \mathrm{Vmax}=2.5 \mu \mathrm{moles}$ prothrom bin activated/min/mg venom). Gel electrophoretic analysis of prothrombin activation Indicates that the venom activator randomly cleaves the $\operatorname{Arg}_{27.4}{ }^{-}$ $\mathrm{Thr}_{275}$ and $\mathrm{Arg}_{323^{-I l e}} \mathrm{I}_{34}$ bonds of prothrombin since both thrombin and melzothromblin are formed as reaction products. Venom catalyzed prothrombln activation 1 s not affected by bovine Factor Va but 1 greatly stimulated by phospholipids plus $\mathrm{Ca}^{2+}$ Ions. This stimulatory effect is explatned by a decrease of the $\mathrm{Km}$ for prothrombin. In the presence of $50 \mu \mathrm{M}$ phospholiptd. vestcles (phosphatidylserine/phosphatidylchollne, 25/75; mole/mole) the Km is $0.34 \mu \mathrm{M}$ and the $V_{\max } 1 \mathrm{~s} 7.1$ moles prothrombln act 1 vated $/ \mathrm{m} / \mathrm{n} / \mathrm{mg}$ venom. The purfified venom activator contalns $\psi$-carboxyglutamic acid residues whlch presumably function in the interaction between the venom activator and phosphollpids. Treatment of the activator with $0.8 \mathrm{M}$ NaSCN strongly reduces its ability to activate prothrombin but has no effect on 1 ts amidolytic activity. The prothrombin-converting activity of the NaSCN-treated activator can be restored with bovine Factor Va.

During prolonged gradient gel electrophorests the $M_{r} 300,000$ activator dissociates into smaller subunits. This causes a loss of the prothrombinconverting activity, while the amidolytic activity in recovered in a protein with an apparent molecular welght of 57,000 . Th1s protein can, 
however, rapldy actlvate prothrombin in the presence of Factor Va or in the presence of a protefin component of $\mathrm{M}_{\mathrm{r}} 220,000$ that also migrates in the gel. The results suggest that the prothrombin activator from the oxyuranus scutellatus venon 18 multheric protein complex consisting of a Factor Xa-11ke enzyme and Hactor Va-11ke cofactor.

\section{INTRODUCTION}

A central reaction in blood coagulation is the activation of the zymogen prothrombin to the serine protease thrombin. This reaction, which is catalyzed by Factor Xa, 1 s accelerated by $\mathrm{Ca}^{2+}$ Ions, phospholiplds and Factor Va. Kinetic studles have shown that phospholipids promote prothrombin activation by decreasing the $\mathbb{K m}$ for prothrombin (1), whereas factor Va enhances prothrombin activation by a) causing a 1000-fold increase in the $k_{c a t}$ of prothrombin activation $(1,2)$, b) promoting the binding of Factor Xa to the phoshollpld surface $(2,3)$ and c) lowerling the $\mathrm{Km}$ for prothrombin, a feature which becomes most striking when phospholipids with a low affintty for prothrombin are used $(4,5)$. However, the molecular mechanisms underlying these kinetic effects remain unclear.

Several snake venoms contalin procoagulant protelns that can activate zymogens that particlpate in blood coagulation. Since the mechanisms by Which venom enzymes activate coagulation factors often differ from those of the mammalian enzymes, venom activators can provide additional information about the molecular mechanisms of coagulation factor activation. With respect to prothrombin activation, venom activators can have widely different properties. The prothrombln activator from Echis carinatus rapldily converts prothrombin into melzothrombin $(6,7)$ in a reaction that is not affected by phosphollptd or Factor Va. Prothrombin activation by the activator from Notechls scutatus scutatus (Malnland Tiger snake) is greatly stimulated by both Factor Va and phospholiplds $(8,9)$, whereas prothrombin activation by the venom activator from Oxyuranus scutellatus (Taipan snake) 1 s enhanced by the presence of phosphollpids $(10,11)$.

In this paper, we describe the purffication and the structural and functional characterization of the prothrombin activator from oxyuranus scutellatus venom. It is shown that this venom activator is a multimeric 
protein complex comprised of a catalytic unt associated wh a coftctor part that is regulred for efflcient prothrombin activation. The catytic unt has many propertles in comon with Factor $X a$, whereas the cofactor part presumably functions like Factor Va.

\section{EXPER IMENTAL PROCEDURES}

Reagents. $52238,52337, \$ 2222$ and 12581 were purchased from AB Kab1 Dlagnostica. Ovalbum, human serum album (fatty acld free), benzanidineHC1 and 1,2-dloleoy1-sn-glycero-3-phosphocholine (PC) were fron sigma. Dansy $1-\mathrm{Glu}-\mathrm{Gly}-\mathrm{Arg}-\mathrm{CH}_{2} \mathrm{Cl}$ was purchased from Galblochem and $\mathrm{p}$-NPGB was from ICN Nutritional Biochenlcals. Heparin (USP activity $175 \mathrm{v} / \mathrm{mg}$ ) was obtalned from Organon. DEAE-Sephadex A-50, QAE-Sephadex A-50, SP-Sephadex C-50, sephadex G-100 and G-200, polyacrylamide gradient ge1s PAA 4/30 and callbration kits for electrophoresls were purchased from Pharmacia. Lyophilized crude snake venoms were obtained from Stgma. As indicated by the manufacturer the venom of oxyuranus scuteliatus may be from the subspecte cann (papuan talpan) or scutellatus (australian talpan) or a mixture of both.

Protelns. Bovine prothrombin was purifled according to the method of owen et a1. (12). Thrombin was purifted as described earlfer (1). Bovine Factor $\mathrm{Xa}$ was purifled by the method of Fujlkawa et a1. (13). Factor $\mathrm{V}$ and Factor Va were obtalned as described by Lindhout et al. (3). The proteln preparations were stored at $-80^{\circ} \mathrm{C}$ in $50 \mathrm{mM}$ Tr1s-HC1, $175 \mathrm{mM} \mathrm{NaCl,} 0.5$ $\mathrm{mg} / \mathrm{ml}$ human serum albumin ( $\mathrm{pH} 7.9$ ). Factor Va was stored in the same buffer contalning $5 \mathrm{mM} \mathrm{CaCl}_{2}$. Purified venom preparations were stored at $-80{ }^{\circ} \mathrm{C} 1 \mathrm{n}$ $50 \mathrm{mM}$ Hepes, $150 \mathrm{mM} \mathrm{NaC1}, 10 \mathrm{mM}$ benzamidine $(\mathrm{pH} 7.2)$.

Protein concentrations. The molar concentrations of thrombin (14) and Factor Xa (15) were determined by active site titration with $p$-NPGB. Prothrombin concentrations were determined by the same method after complete activation with Echis carinatus venom. Factor Va concentration was determined by kinetic analysis as described by Lindhout et al. (3). The concentration of purified activator from oxyuranus scutellatus was 
calculated frow a protein detemination according to Sedmak et aI. (16), using bovine serum album in as standard, and asuming a molecular weight of 300,000 for the venom activator (see results).

Phosphollple and phosphollpld vesicle preparations. PS was prepared from PC by enzymatic synthesis (17). Single bllayer phospholipld vesicles were prepared by sontcation of mixtures of 25 mol \% PS and 75 mol \% PC, or 5 mol \% PS and 95 mol \% PC as described before (1). Phosphollpid concentrations were determined by phosphate analysis according to Bottcher et al. (18).

Assay system for measurement of prothrombin activation. The activation of prothrombin by oxyuranus scutellatus was followed by measuring the generation of amidolytic activity (thrombin plus melzothromblin, cf. ref. 19) towards the chromogentc substrate $\$ 2238$. Appropriate dilutions of the venom activator were preincubated for 5 minutes at $37{ }^{\circ} \mathrm{C}$ in a buffer contalnung $50 \mathrm{mM}$ TrAs-HCl ( $\mathrm{pH} 7.9$ ), $175 \mathrm{mM}$ NaCl and $0.5 \mathrm{mg} / \mathrm{ml}$ human serum albunin. When present, the cofactors $\mathrm{CaCl}_{2}$, phosphollpld vesicles, or Factor Va were included in the preincubation mixture. Prothrombin activation was started with the addition of prewarmed prothrombin in the same buffer. After different time intervals, samples were taken and transferred to cuvettes containing $50 \mathrm{mM}$ Tr1s-HCl (pH 7.9), $175 \mathrm{mM} \mathrm{NaCl}, 20$ $\mathrm{mM}$ EDTA, $0.5 \mathrm{mg} / \mathrm{ml}$ ovalbumin and $235 \mu \mathrm{M} 52238$ (1 $\mathrm{ml}$ final volume). The converston of 52238 was followed by measuring the absorbance change on an Aminco DW-2C spectrophotometer set In the dual wavelength mode at 405-500 nom. From a calibration curve, made with known amounts of active sitetitrated thrombln, the amounts of activated prothrombin in the reaction mixture could be determined.

Determination of the catalytlc activity of the venom activator. The pror thrombin-converting activity of venom activator preparations was routinely assayed in reaction mixtures that contained $0.5 \mu \mathrm{M}$ prothrombin, $50 \mu \mathrm{M}$ phosphollpid (PS/PC, 25/75; mole/mole), $5 \mathrm{mM} \mathrm{CaCl}_{2}$ elther with or without 5 nM Factor Va and appropriate dilutions of the venom activator preparation. The rate of prothrombin activation was determined as descrtbed above.

The amidolytic activity of the venom activator was measured in cuvettes contalning $50 \mathrm{mM}$ Tris-HCl ( $\mathrm{pH} 7.9), 175 \mathrm{mM} \mathrm{NaCl}, 20 \mathrm{mM}$ EDTA, $0.5 \mathrm{mg} / \mathrm{ml}$ 
ovalbumin, and $197 \mu \mathrm{k}$ s2337. The conversion of 52337 was followed by measuring the absorbance change on an Anlnco DW-2C spectrophotometer set in the dual wavelength mode at 405-500 nn. The rate of p-nitroaniline formation was calculated using an $\mathbb{E}_{405}$ of $1.04 \times 10^{4}$ mol $^{-1} \cdot 1 . \mathrm{cm}^{-1}$ for p-nitroanline.

Gel electrophoretic techniques. The subunit structure of the venom prothrombin activator was analyzed by electrophoresis in the presence of SDS on acrylamide tube gels according to the method of Laemm (20). The molecular weight of the venom activator was determined by electrophoresis under non-denaturing conditions on Pharmacla gradient gels (PAA 4/30) following the instructions of the mafacturer. Analysis of the activation products generated during prothrombin cleavage by the venom activator was carried out by SDS-polyacrylamide gel electrophorests on $10 \%$ acrylamide slab gels according to the method of Laemil (20). Further expertmental detalls are given in the legends to the flgures.

\section{RESULTS}

Puriflcation and characterization of the prothrombin activator from oxyuranus scutellatus. The prothrombin-activating enzyme from oxyuranus scutellatus was purifled from the crude venom by gel filtration on Sephadex G-200 followed by QAE-Sephadex lon-exchange chrowatography. In order to prevent autodegradation of the actlvator, 10 mM benzamidine was present in all buffers used in the purification procedure. Detalled Information regarding this puriflcation procedure is glven in the legend to Table $I$. Separation on Sephadex G-200 gave five major proteln peaks, the first of which contalned both prothrombin-converting and $\$ 2337$ hydrolage activity. Purlfication in this step was about 10-fold with a $66 \%$ ylleld (Table I). QAE-Sephadex lon-exchange chromatography gave a further 2-fold purification and a final overall yield of $30 \%$. The galn in spectflc activity indlcates that the activator comprised at most $5 \%$ of the crude venom. Walker et 1 . (11) reported that the crude venom of oxyuranus scutellatus scutellatus contains an inhibitor of the coagulant and amidolytic activity that was removed durling the tsolation procedure. The crude venom of oxyuranus 
Table I

Purlfication of the prothrombin activator

from the venom of Oxyuranus scutellatus

Crude venon (100 mg) was dissolved in $4 \mathrm{ml} 50 \mathrm{mM}$ Hepes ( $\mathrm{pH} 7.2), 150 \mathrm{mM}$ Mac1, $10 \mathrm{mM}$ benzaridine, and applled to a sephadex $G-200$ column $(2.5 \times 90 \mathrm{~cm})$ at a flow rate of $15 \mathrm{ml} / \mathrm{h}$ at $4^{\circ} \mathrm{C}$. After elution, the fractlons containing prothrombin-converting activity were pooled and applied to a QAE-Sephadex A-50 colum $(1 \times 20 \mathrm{~cm})$. The activator adhered to the resin and was eluted wth a lineat gradlent $(2 \times 60 \mathrm{ml}$ ) of 150 to $350 \mathrm{mM}$ NaCl in $50 \mathrm{mM}$ Hepes ( $\mathrm{pH}$ 7.2), $10 \mathrm{mM}$ benzamidine. The activator eluted in a single peak at about 200 mM NaCl. The prothrombin-converting activity of the venom activator was assayed as described in the experfmental procedures.

Total protein

(mg)

Speciflc Activity Recov
(nmoles prothrombin
activated/min/ug venom)

Specific Activity ctivated/min/ug venom)
Recovery Puriflcation

(\%)

Factor

\begin{tabular}{lrrrr}
\hline Crude venon & 100 & 0.2 & 100 & 1 \\
Sephadex G-200 & 6.3 & 2.1 & 6.6 & 10 \\
QAE Sephadex & 1.7 & 3.5 & 30 & 18 \\
\hline
\end{tabular}

scutellatus (subspecles scutellatus or cannf or a mixture of both) used as starting materlal in our study apparently did not contain such an inhibltor since nelther the recovery of amidolytic activity nor the recovery of prothrombin-converting activity was increased during the puriflcation procedure.

SDS gel electrophores1s of the purifled activator on $7.5 \%$ acrylamide tube gel (Fig. 1) showed four major proteln bands with apparent molecular weights of $220,000,120,000,80,000$ and 60,000 . Upon reduction with $\beta$-mercaptoethano1 three bands were present with molecular weights of $110,000,80,000$ and 30,000 . The activator could be 1rreversibly inhibited wth the active ste-directed chloromethyl ketone dansyl-G1u-Gly-Arg-CH${ }_{2} \mathrm{Cl}$.

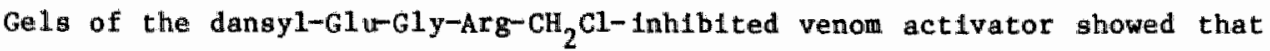
the fluorescent inhibitor was almost exclusively incorporated in the $M_{r}$ 60,000 band on non-reduced gels and in the $M_{r} 30,000$ band on reduced gels (F18. 1). Th1s Indicates that the $M_{r} 60,000$ subuntt contains the active site of the venom activator. 


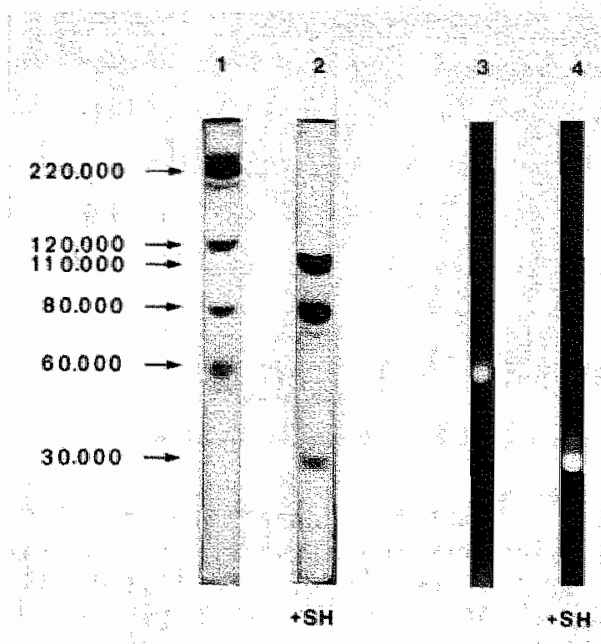

Fig. 1. Polyacrylamide gel electrophoresis of the purlfied prothrombin activator from the venon of oxyuranus scutellatus. Active site-labeled activator was obtalned by incubating $2.5 \mathrm{~m}$ of activator $(62 \mu \mathrm{g} / \mathrm{m} 1)$ wh 40 UM dansy1-GIu-GIy-Arg- $\mathrm{CH}_{2} \mathrm{Cl}$ at $22{ }^{\circ} \mathrm{C}$ for $20 \mathrm{~min}$. Excess inhibitor was removed by dialysis, and the activator was concentrated in an

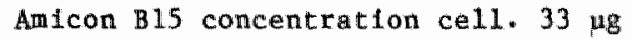
of activator (lanes 1 and 2) or active site-labeled activator (lanes 3 and 4) were subjected to gel electrophoresis on $7.5 \%$ gels in the presence of sodium dodecyl sulfate according to Laemil (20). $5 \%$ $\beta$-mercaptoethanol was present in reduced samples. The gels containing activator were stained with Coomassie Brilliant Blue $\mathrm{R}-250$, and the gels contalning the active site-labeled activator were photographed under UV 1 ight using a yellow fllter (cutoff-400 nm). The molecular weights of the subunits, which are indicated in the flgure, were determined in a separate experiment on $5 \%$ gels (subunits with $\mathrm{M}_{\mathrm{r}}>100,000$ ) or $10 \%$ gels (subunits with $M_{I}<100,000$ ).

Catalytic properties of the purifled venom activator. The purifled prothrombin activator from oxyuranus scutellatus venom readily cleaves a number of commerclally awallable chromogenic substrates that have been designed for Factor $\mathrm{Xa}$. The kinetic parameters for chromogenic substrate conversion by the venom activator and by bovine Factor Xa, which were obtained from Lineweaver-Burk plots (F1g. 2), are compared in Table II. For al1 chromogenic substrates tested, the amldolytic activity of the venom activator was lower than that of Factor Xa. Factor $\mathrm{Va}$ and $\mathrm{Ca}^{2+}$ Ions had no effect on the catalytic efficlency.

The purffled venom activator was also able to activate prothrombin. Venom-catalyzed prothrombin activation was stimulated about elght times by $\mathrm{Ca}^{2+}$ Ions and was not affected by the presence of Factor Va. Phosphollplds $(50 \mu \mathrm{M})$ plus $\mathrm{Ca}^{2+}$ lons $(5 \mathrm{mM})$ caused a 3000 -fold rate enhancement of prothrombin activation by the venom activator. This stimulatory effect of phosphollpids plus $\mathrm{Ca}^{2+}$ was observed both in the absence and presence of Factor Va. Further detalls about prothrombin activation by the purified venom activator are given in the paragraph on the determination of the kinetic parameters of venom-catalyzed prothrombin activation (see below). 

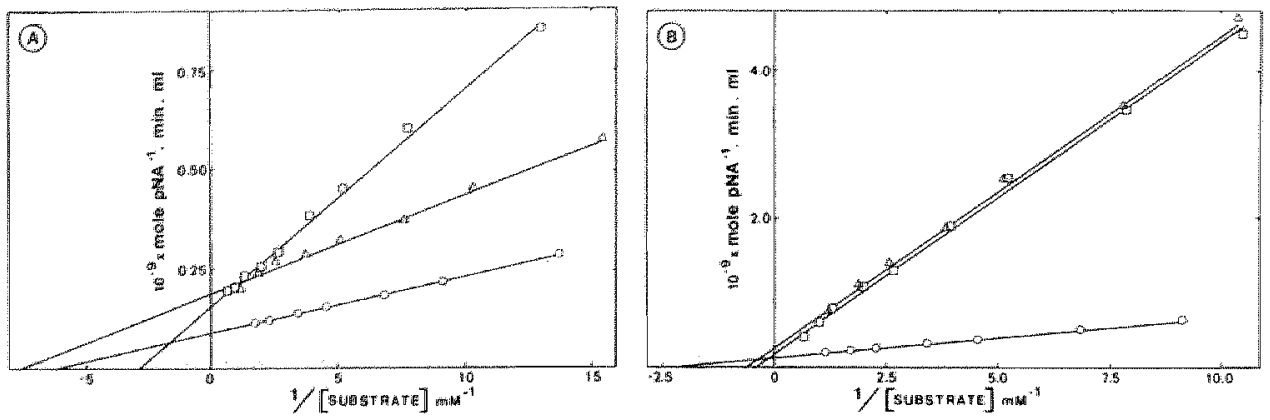

F1g. 2. Lineweaver-Burk plots of chromogenic substrate conversion by Factor $\mathrm{Xa}$ and the venom act1vator from Oxyuranus scutellatus. Chromogenic substrate conversion by $0.5 \mathrm{nM}$ Factor Xa (A) or $1.1 \mathrm{nM}$ purified venom activator (B) was measured at $37^{\circ} \mathrm{C} 1 \mathrm{n} 50 \mathrm{mM} \mathrm{Tr} / \mathrm{s}-\mathrm{HCl}$ (pH 7.9), $175 \mathrm{mM} \mathrm{NaCl}$, and $0.5 \mathrm{mg} / \mathrm{ml} \mathrm{HSA}$. The chromogentc substrates used were $\$ 2222(\square-\square), \$ 2337(\Delta-\Delta)$, and the Pentapharm Factor Xa substrate $\mathrm{CH}_{3} \mathrm{OCO}-\mathrm{D}-\mathrm{CHG}-\mathrm{Gly}-\mathrm{Arg}$-pNA. ACOH (O-O). p-nitroantline ( $\mathrm{PNA}$ ) formation was measured as described in the experimental procedures. The molar concentration of venom activator in the reaction mixture was calculated from the amount of venom activator protein present, and using a molecular weight of 300,000 for the activator.

\section{Table II}

\section{RInetic parameters for chromogenic substrate conversion by Pactor Xa and the venom activator from Oxyuranus scutellatus}

Kinetic parameters for chromogenle substrate conversion were obtalned from LIneweaver-Burk plots (F1g. 2) after statistical analysis according to Elaenthal and Cornish-Bowden (21).

Chromogendc

substrate

Venom activator

K

$\mathrm{k}_{\text {cat }}$

$\mathrm{k}_{\mathrm{cat}} / \mathrm{k}_{\mathrm{m}}$

$\mathrm{K}_{\mathrm{m}}$

$k_{\text {cat }} k_{\text {cat }} / \mathrm{k}_{\mathrm{m}}$

$(\mu M)$

$\left(s^{-1}\right)$

$\left(M^{-1} s^{-1}\right)$

(uM)

$\left(\mathrm{s}^{-1}\right)\left(\mathrm{M}^{-1} \mathrm{~s}^{-1}\right)$

\begin{tabular}{lrrrrrr}
\hline$\$ 2222$ & 346 & 211 & $0.6 \times 10^{6}$ & 2349 & 83 & $0.35 \times 10^{5}$ \\
$\$ 2337$ & 130 & 173 & $1.3 \times 10^{6}$ & 1531 & 55 & $0.36 \times 10^{5}$ \\
Pentapharm $^{\text {a }}$ & 157 & 376 & $2.4 \times 10^{6}$ & 434 & 124 & $2.90 \times 10^{5}$
\end{tabular}

Pentapharm Factor Xa Substrate: $\mathrm{CH}_{3} \mathrm{OCO}-\mathrm{D}-\mathrm{CHG}-\mathrm{G} 1 \mathrm{y}-\mathrm{Arg}-\mathrm{pNa} \cdot \mathrm{ACOH}$ 
Molecular weight determination of the purifted venom activator. Polyacrylamide gradient gel electrophoresis under nor-denaturing conditions was performed to establish the molecular wefght of the purffled activator. After electrophoresis, the gel was sliced, and the gel slices were eluted and assayed for amldolytic activity toward $\$ 2337$ and prothrombin-converting activity (Fig. 3). It appeared that there were two bands with 52337

\section{MOLECULAR WEIGHT MARKERS}

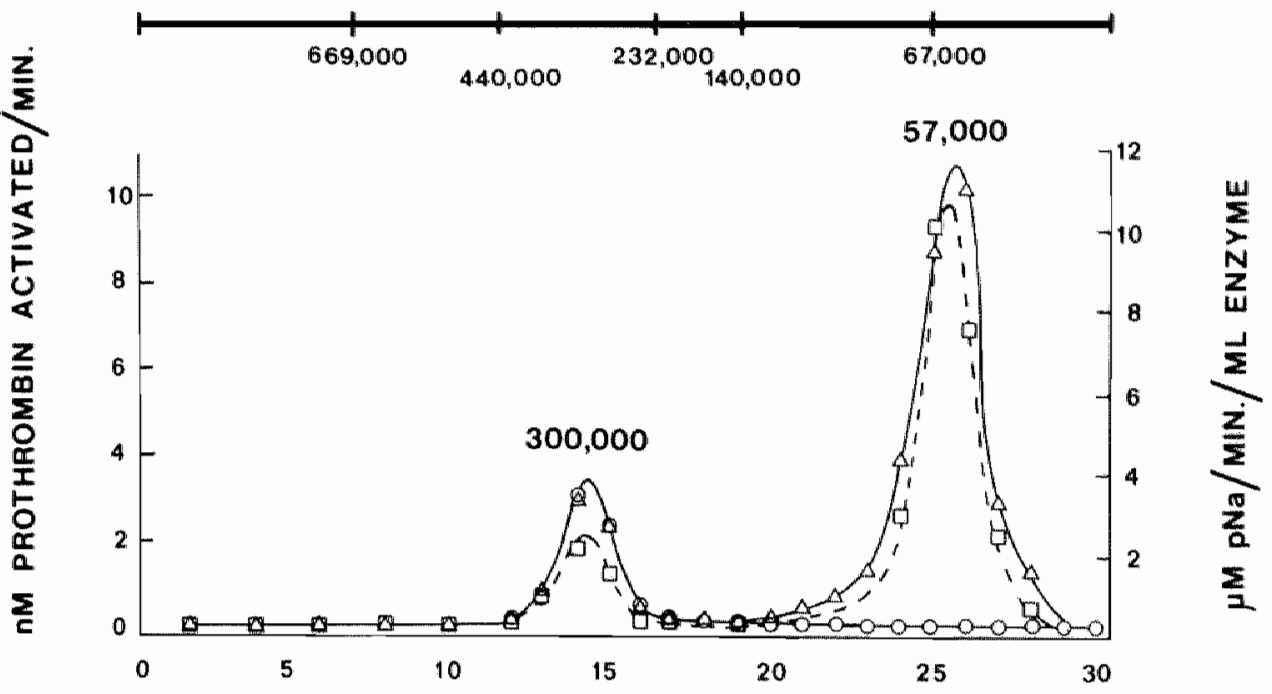

SLICE NUMBER

Fig. 3. Gradlent gel electrophores1s of the purlfled prothrombin activator

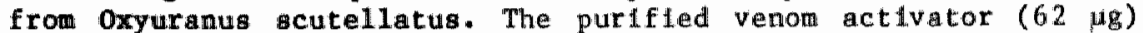
was subjected to electrophoresis under non-denaturing condittons on a Pharmacla PAA 4/30 gradient gel. Part of the gel reserved for the molecular welght markers thyroglobulin $\left(M_{r} 669,000\right)$, ferritin $(M, 440,000)$, catalase $\left(M_{r} 232,000\right)$, lactate dehydrogenase (M $14 \delta, 000)$, and bovine serum albumin $\left(M^{\prime} 67,000\right)$. After electrophó resis, the gel was sliced (2.5 mm silces) and the protein was eluted from the gel by shaking the gel slices for $48 \mathrm{~h}$ at $4^{\circ} \mathrm{C}$ in 1 ml of $50 \mathrm{mM} \mathrm{Tr1s-HCl}$ ( $\mathrm{pH} 7.9$ ), $175 \mathrm{mM} \mathrm{NaCl}, 5 \mathrm{mM} \mathrm{CaC1}$ contalning $0.5 \mathrm{mg} / \mathrm{m} 1 \mathrm{HSA}$. The prothrombin-converting activity in $\mathrm{I}_{1} \mathrm{l}$ of the gel eluate was determined in the absence $(O-O)$ and presence of Factor Va $(\Delta-\Delta)$. The amidolytic activity in $100 \mu 1$ of eluate was determined with 52337 ( $\square-\square)$. Further detalls about these assays are glven in the experimental procedures. The part of the gel that contalned the molecular welght markers was stalned with $0.05 \%$ Amido Black, and the migration distance of the marker proteins $1 \mathrm{~s}$ indlcated in the flgure. 

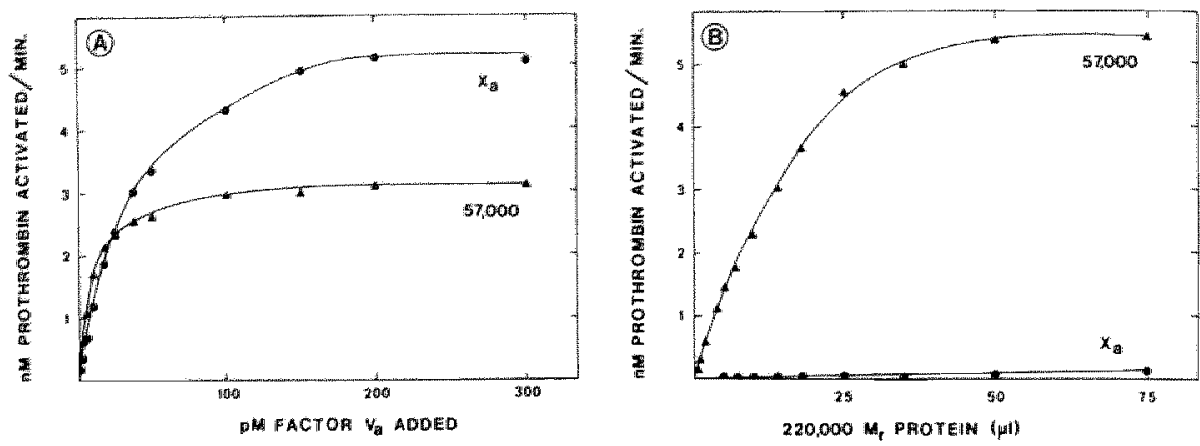

F1g. 4 Prothrombin activation by the $M_{5} 57,000$ subunit of 0xyuranus cutellatus: effect of Factor $\mathrm{Va}$ and the $M_{r} 220,000$ component.

The eluate of fraction 26 of the gradient gel (Fig. 2) contalning the $M, 57,000$ subunit of the venom activator was diluted $10-$ fold, and $2 \delta \mu 1$ of this dilution ere incubated at $37^{\circ} \mathrm{C}$ in $180 \mu 1$ of 50 $\mathrm{mML}$ Tris-HCl ( $\mathrm{pH} \mathrm{7.9),} 175 \mathrm{mM} \mathrm{NaCl}, 5 \mathrm{mM} \mathrm{CaCl} 2$, and $0.5 \mathrm{mg} / \mathrm{ml}$ human serum albumin contalning different amounts of Factor Va $(\Delta-A, A)$ or the eluate of the gel fraction 17 which contalns the $M_{r} 220,000$ component $(\Delta-\Delta, B)$. After $6 \mathrm{~min}, 20 \mu \mathrm{l}$ of this mixture were added to $430 \mu 1$ of the same buffer contalning $50 \mu \mathrm{M}$ phospholipid (PS/PC, $25 / 75$; mole/mole). 5 min later, $50 \mu 1$ of $5 \mu \mathrm{M}$ prothrombin was added, and the rate of prothrombin activation was measured as described in the experimental procedures. In a similar experiment, $40 \mathrm{pM}$ Factor Xa was titrated with varying amounts of Factor Va (-), A) or M 220,000 eluate (-), B). The amounts of Factor Va or the $M 220,006$ component indicated in the figure are those present in the final prothrombin activation mixture (Factor Va) or in the prelincubation mixture $\left(M_{r} 220,000\right.$ component $)$.

hydrolase activity: one at a molecular weight of about 300,000 and one at 57,000. The prothrombtn-converting act1vity of these two bands was, however, markedly different. The $M_{r} 300,000$ protein rapidly activated prothrombin, and its activation rate was not affected by Factor Va. Prothrombin conversion by the $M_{r} 57,000$ proteln was very slow, but was 8 reat1y Increased in the presence of bovine Factor Va. In F1g. 4A, it is shown that low amounts of Factor Va were required to obtain maximal prothrombin-converting activity of the $M_{r} 57,000$ proteln. This indicates that the latter protein has a high affimity for Factor Va. For comparison, a Factor Va titration of a 11mited amount of Factor Xa is also included in this flgure.

Recombinations of gel slice eluates showed that there was another protein band, with a molecular welght of about 220,000, which, 11ke Factor Va, stimulated prothrombin activation by the $M_{r} 57,000$ eluate. The ${ }_{r} 220,000$ 
eluate had no catalytic activity but restored prothrombln activation by the ${ }_{r}$ 57,000 proteln band in a concentration-dependent manner (Fig. 4B). The $\mathrm{M}_{\mathrm{I}} 220,000$ protein band was, however, not able to stimulate Factor Xarcatalyzed prothrombin activation. Since the experiments presented in Figs. 4 (A and $B$ ) were carried out at the same concentration of the $\mathrm{M}_{\mathrm{r}} 57,000$ subunit, It should be noted that saturation with the $\mathrm{M}_{\mathrm{r}} 220,000$ component gives an enzyme-cofactor complex that is twice as active as the complex obtained upon saturation with bovine Factor Va.

When the purifled venom activator was subjected to prolonged electrophoresis on the gradient gels, the active species with $M_{r} 300,000$ complete1y disappeared, whereas the activity of the $M_{r} 57,000$ component was increased (data not shown). This indicates that the native venom activator 18 a high molecular welght protelin $\left(M_{r} 300,000\right)$ that can dissoclate into an enzymatic component $\left(M_{r} 57,000\right)$ with high amldolytic and low prothromblnase activity and a cofactor part $\left(M_{r} 220,000\right)$ which stimulates the prothrombinconverting activity of the enzymatic component.

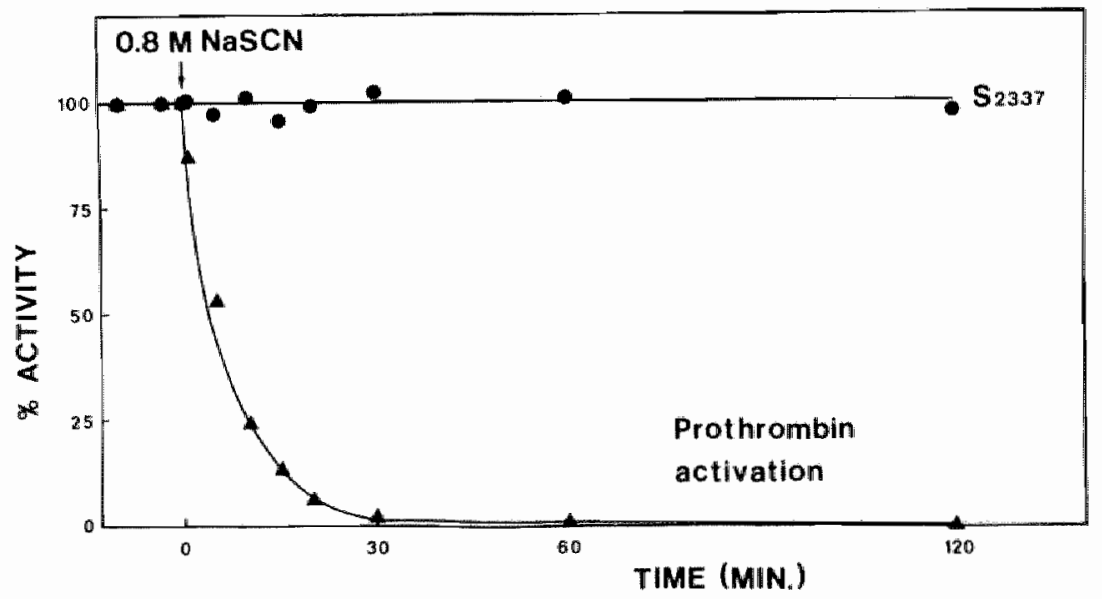

Fig. 5. Effect of MaSCN on the catalytic actlvity of the prothrombin act1vator frow oxyuranus scutellatus. The purffled venom activator was Incubated at $37{ }^{\circ} \mathrm{C}$ at a concentration of $62 \mu \mathrm{g} / \mathrm{m} 1$ in $50 \mathrm{mM}$ Hepe ( $\mathrm{pH} 7.2), 150 \mathrm{mM} \mathrm{NaCl}$, and $0.5 \mathrm{mg} / \mathrm{ml}$ human serum albumln. At zero tIme, NaSCN was added to a final concentration of $0.8 \mathrm{M}$. At the time Intervals indicated, samples from this mixture were diluted and assayed for amidolytic activity toward $\$ 2337$ (-) or prothrombin-converting activity $(\boldsymbol{\Delta}-\boldsymbol{\Delta})$. Further detalls about the amidolytic assay and the prothromblnase assay, whlch was carrled out in the presence of $50 \mu \mathrm{M}$ phospholiptd, but whout Factor Va, are glven in the experimental procedures. The low amount of NaSCN present in the diluted venom aliquots did not interfere with these assays. 
Treatment of the venom actlvator wh sodlum thiocyanate (NaSCN).

Since

It $1 \mathrm{l}$ likely that the 57,000 proteln $1 \mathrm{~s}$ derlved from dissociation of the native actlvator, we searched for a way to treat the venom activator so that it would retaln its anldolytic activity toward $\$ 2337$ but would lose Its prothromblti-converting activity. Walker et al. (11) have shown that Incubation of the venom from the subspecies oxyuranus scutellatus scutellatus in 2. MaCl results in a loss of procoagulant activity while the $\$ 2222$ hydrolage act1v1ty remains constant. We observed that the loss of prothrombin-converting activity of the purifled venom activator from Oxyuranus scutellatus in the presence of $2 \mathrm{M}$ NaCl 1 , however, rather slow $\left(t_{1}>2 \mathrm{~h}\right)$. The prothrombln-converting activity of the venom activator is rapldy logt upon incubation with $0.8 \mathrm{M}$ NaSCN (F1g. 5). Within $30 \mathrm{~m} 1 \mathrm{n}$, more than $95 \%$ of the venom activity in prothrombin activation was lost. The amidolytic act1vity toward $\$ 2337$ was not affected by incubation of the venom activator with NaSCN.

\section{Table III}

Effects of phospholipid plus $\mathrm{Ca}^{2+}$ and Factor $\mathrm{Va}$ on prothrombin activation by the complete purffied activator and the NaSCN-treated activator from Oxyuranus scutellatus venom

$0.5 \mu M$ prothrombin was activated by appropriate dilutions of the purlfied venom activator or the NaSCN-treated activator in $50 \mathrm{mM} \operatorname{Tr} 1 \mathrm{~s}-\mathrm{HCl}$ ( $\mathrm{pH} 7.9$ ), $175 \mathrm{mM} \mathrm{NaCl}, 0.2 \mathrm{mM}$ EDTA, $0.5 \mathrm{mg} / \mathrm{ml}$ HSA either in the absence or in the presence of $5 \mathrm{mM} \mathrm{CaCl}, 5 \mathrm{nM}$ Factor Va (Va), and/or $50 \mu \mathrm{M}$ phosphollpld (PL) vesicles contalning $25 \mathrm{~mol} \%$ PS and 75 mol \% PC. The NaSCN-treated activator was obtalned by Incubating the purlfied venom actvator $(62 \mu \mathrm{g} / \mathrm{m} 1)$ for $2 \mathrm{~h}$ in the presence of $0.8 \mathrm{M}$ NaSCN followed by dialysis against $50 \mathrm{mM}$ Trlis-HC1 (pH 7.9), $175 \mathrm{mM} \mathrm{NaCl}$. Prothrombln activation was determined as described in the experimental procedures, and the rate measured with the native activator whout accessory components, 1.61 nmol prothrombin act Ivated $/ \mathrm{min} / \mathrm{mg}$ venom, was arbitrarely taken as 1 .

Native activator

Activator

(relative rate)

NaSCN-treated activator

(relative rate)

Venom

Venom, $\mathrm{Ca}^{2+}$

Venom, $\mathrm{Ca}^{2+}$, Va

Venom, $\mathrm{Ca}^{2+}, \mathrm{PL}$

Venom, $\mathrm{Ca}^{2+}, \mathrm{PL}, \mathrm{Va}$
$<0.03$

$<0.03$

0.35

1.75 
The prothrombin-converting activity of the NasCN-treated activator could be restored with bovine Factor Va. This effect 1 is most clearly seen upon comparison of the relative rates of prothrombin activation by the purdfled activator and the NaSCN-treated activator in the presence of different accessory components (Table III). With both forms of the activator, prothrombin activation was stimulated by phospholiplds plus $\mathrm{Ca}^{2+}$. Factor Va, which did not stimulate the native venom activator, drastically increased the rate of prothrombin activation by the NascN-treated activator. This rate enhancement by Factor Va was observed in the presence as well as in the absence of phospholltids.

KInetic parameters of venom-catalyzed prothrombln activation. To gain more insight in the mechanism by which phosphollpids plus $\mathrm{Ca}^{2}+$ stimulate the catalytic activity of the natlve venom activator and how Factor va stimulates the NaSCN-treated activator, we have determined the kinetic parameters of venom catalyzed prothrombin activation in activation mixtures

of different compositions. Prothrombin activation was determined by measuring the generation of amidolytic activity toward 52238 . Prothrombin activation was IInear with time and proportional with the amount of wenom activator present, and Michaelis Menten kinetics was abserved. The kinetic parameters were obtalned from Lineweaver-Burk plots, a few typlcal examples of which are shown in Fig. 6. The kinetlc parameters for venom-catalyzed prothrombin activation are sumarized in Table IV.

Prothrombin activation by the native activator lone was characterized by a very $\mathrm{h} / \mathrm{gh} \mathrm{Km}$ and a relatively high Vmax. The catalytic activity of the native venom actlwator was hardly affected by Factor va elther in the absence or in the presence of phospholipids. Phospholipids drastcally decreased the Km for prothrombin and had only a small effect on the Vmax. To obtalln a phospholipld-dependent decrease of the Km, the procoagulant membranes had to contaln negatively charged phospholiplds such as phosphatidylserine. Prothrombin activation by the native activator was, however, rather insensitive to varying the amount of negatively charged phospholipid in the procoagulant membranes since the same kinetic parameters were found for vesicles contalning 5 and 25 mol \% phosphat idylserine. 

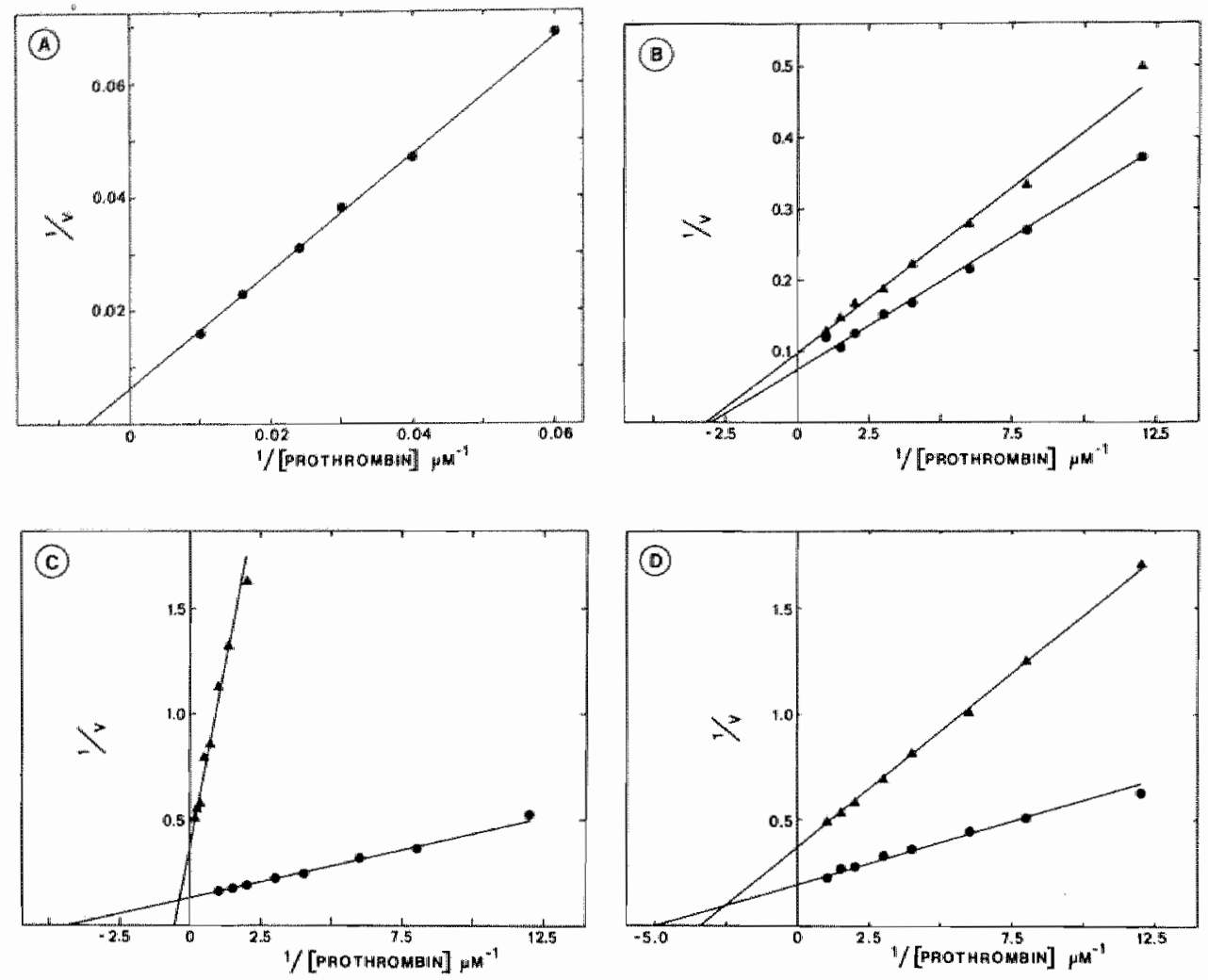

Fig. 6. Lineweaver-Burk plots of prothrombln activation by the mative and NaSCN-treated prothrombin activator from the venom of Oxyuranus scutellatus. Appropriate dilutions of the purifled venom activator or the NaSCN-treated activator (obtalned as described in the legend of Table III) were prezncubated in $300 \mu 1$ of a buffer containing 50 $\mathrm{mM} \operatorname{Tr} 1 \mathrm{~s}(\mathrm{pH} 7.9), 175 \mathrm{mM} \mathrm{NaCl}, 5 \mathrm{mM} \mathrm{CaCl}, 0.5 \mathrm{mg} / \mathrm{ml} \mathrm{HSA}$, elther wth or without phospholipid vesicles and/or factor Va. After 5 min, prothrombin activation was started by the addition of $200 \mu 1$ of the same buffer ( prewarmed at $37^{\circ} \mathrm{C}$ ) containing varlous amounts of prothrombin. The rate of prothrombin activation ( $V$, pmoles of prothrombln activated per min per ml reaction mixture) was determined as described in the experimental procedures. The prothrombin-activating complex consisted of:

A) $64 \mathrm{ng} / \mathrm{ml}$ native venom activator

B) $1.9 \mathrm{ng} / \mathrm{m} 1$ native venom activator and $50 \mu \mathrm{M}$ phospholipid vesicles, contalning $25 \%$ PS/75\% PC (-) or $5 \%$ PS/95\% PC ( $\Delta-\boldsymbol{\Delta})$

c) $1.7 \mu \mathrm{g} / \mathrm{m} 1 \mathrm{NaSCN}-t$ reated activator and $50 \mu \mathrm{M}$ phospholipld vieslcles, containing $25 \%$ PS/75\% PC (-0) or $5 \%$ PS/95\% PC $(\Delta-\Delta)$

D) $1.7 \mathrm{ng} / \mathrm{ml}$ NaSCN-treated activator, $5 \mathrm{nM}$ factor $\mathrm{Va}$, and $50 \mu \mathrm{M}$ phospholipid vesicles containing $25 \%$ PS/75\% PC (-) or $5 \%$ PS/95\% PC ( $\Delta-\boldsymbol{\Delta})$ 
Table IV

Kinetic parameters of prothrombin activation by the native and NaSCN-treated prothrombin activator from Oxyuranus scutellatus venom.

The kinetic parameters $\mathrm{Km}$ and $\mathrm{Vmax}$ were obtalned from Lineweaver-Burk plots after statistical analysis according to Elsenthal and Cornish-Bowden (21). Typical examples of LIneweaver-Burk plots are shown in Fig. 6. The final prothrombin activation mixture contained $50 \mathrm{mM}$ Tris (pH 7.9), $175 \mathrm{mM} \mathrm{NaCl}$, $0.5 \mathrm{mg} / \mathrm{ml} \mathrm{HSA}$, varying amounts of prothrombin, approprlate dilutions of the venom activator, $5 \mathrm{mM} \mathrm{CaCl}$, and, when indicated below, $5 \mathrm{nM}$ Factor Va (Va) and/or $50 \mu \mathrm{M}$ phospholipid vesicles (25\% PS/75\% PC or $5 \% \mathrm{PS} / 95 \% \mathrm{PC}$ ).

Native activator NaSCN-treated activator

Activating complex

$\operatorname{Km}(\mu M) \quad \operatorname{Vmax}^{a}$

$\mathrm{Km}(\mu \mathrm{M})$

$\min ^{a}$

\begin{tabular}{|c|c|c|c|c|}
\hline Venom, $\mathrm{Cad}^{2+}$ & 166 & 750 & n.d.b & $\mathrm{n} \cdot \mathrm{d}$. \\
\hline Venom, $\mathrm{Ca}^{2+}, \mathrm{Va}$ & 119 & 550 & $\mathrm{n} \cdot \mathrm{d}$ & $n \cdot d \cdot$ \\
\hline Venom, $\mathrm{Ca}^{2+}, \mathrm{PS} / \mathrm{PC}(5 / 95)$ & 0.32 & 1582 & 2.00 & 0.5 \\
\hline Venom, $\mathrm{Ca}^{2+}, \mathrm{PS} / \mathrm{PC}(5 / 95)$, Va & 0.25 & 1442 & 0.29 & 458 \\
\hline Venon, $\mathrm{Ca}^{2+}, \mathrm{PS} / \mathrm{PC}(25 / 75)$ & 0.34 & 2137 & 0.23 & 1.3 \\
\hline Venom, $\mathrm{Ca}^{2+}, \mathrm{PS} / \mathrm{PC}(25 / 75)$, Va & 0.31 & 2198 & 0.20 & 869 \\
\hline
\end{tabular}

a) Vmax 18 expressed in moles of prothrombin activated per minute per mole of venom. The molar venom concentration was calculated from the amount of purifled venom activator protein using a molecular weight of 300,000 . b) n.d., not determined

We were not able to determine the kinetic parameters of prothrombin activation by the NaSCN-treated activator in the absence of phospholipids since the reaction rates were too low to be measured. However, the kinetle, parameters determined in the presence of phospholiptds yield aufficlent information to galn insight into the changes in the catalytic properties for the NaSCN-treated activator. The NaSCN-treated activator had a low Vmax for prothrombin activation and had an increased $\mathrm{Km}$ for prothrombin when procoagulant membranes with a low percentage of phosphatidylserine were part of the prothrombin-activating complex. The kinetic parameters of the NaSCN-treated activator are affected by Factor Va which causes a considerable increase in the Vmax and a drastlc decrease in the Kar for 
prothrombln when phosphollpid vestcles wth a low mole percent phosphatidylserlne were used. Such effects of Factor Va on the Vmax $(1,2)$ and Km (4,5) have also been observed for Factor Xa-catalyzed prothrombln activation. The kinetic propertles of the non-treated and NaSCN-treated wenom actlvator suggest that the natlve activator is comprised of a Factor Xa-like catalytic untt assoclated with a large molecular weight cofactor wth Factor Va-11ke function. Upon treatment with NaSCN, the cofactor function lis lost, which results in a decreased catalytic capacity that can subsequently be restored wth Factor Va. Factor Va 1s, however, not able to fully restore the prothrombin-converting activity of the activator. This Indlcates that the venom's own cofactor is more active than Factor Va (see also $(1 g \cdot 4, A$ and B).

Pept1de bond cleavage patterns during venom-catalyzed prothrombin actlvation. Since several peptide bonds in prothrombla are susceptible to proteolytic cleavage, different activation products can accumulate during prothrombin activation (FIg. 7). Cleavage of peptide bonds 1 and 2 can be catalyzed by Factor $\mathrm{Xa}$ and can result in the production of prethrombin 2 plus fragment 1.2 (bond 1), melzothrombin (bond 2), or thrombin plus fragment 1.2 (bonds 1 and 2 ). Both melzothroubln and thrombin have thelr active stte serlne exposed and can cleave the chromogenlc substrate 52238 , whereas prethrombin 2 has no enzymatic activity. Thrombin can cleave peptide bond 3 and produce prethrombin 1 plus fragment 1 .

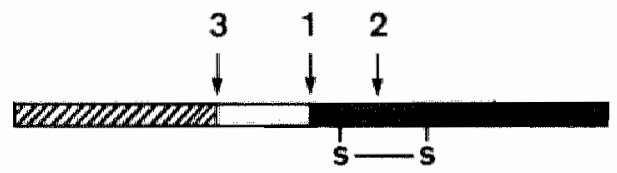

\section{PROTHROMBIN}

Fig * 7. Peptlde bonds in prothrombin susceptible to proteolytic cleavage.

Fig. 8 shows a gel electrophoretic analysis of the time course of prothrombin cleavage by the native venom activator in the presence of $\mathrm{Ca}^{2+}$ plus phospholipid. This experiment was carried out in the presence of the reverglble thrombln inhibitor 12581 in order to slow down feedback 
(A)

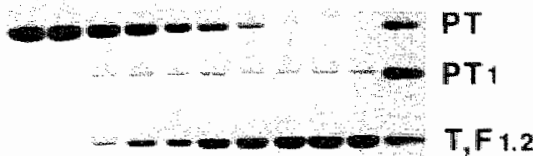

$F_{1}$

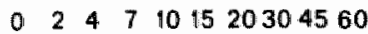

INCUBATION TIME (min.)

(C)

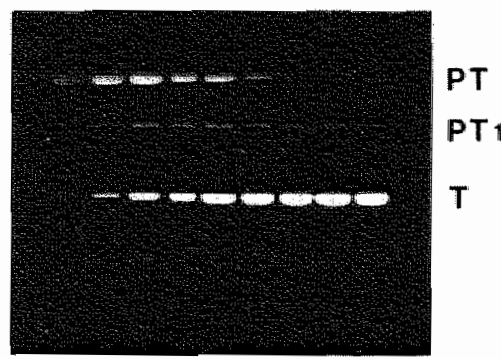

$0 \quad 247101520304560$

INCUBATION TIME (min.)
(B)

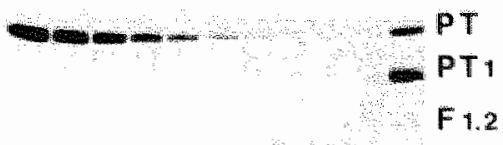

$--0-0-0-T_{b}$

D 2247101520304560

INCUBATION TIME (min.)

(D)

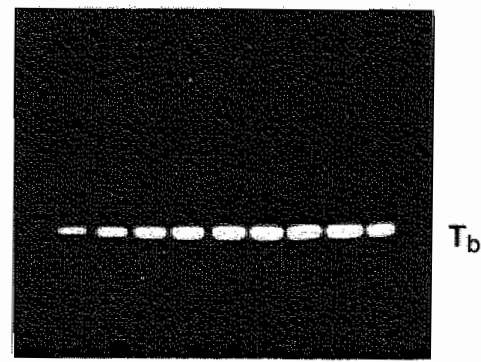

$\begin{array}{lllll}0 & 2 & 4 & 701520304560\end{array}$

INCUBATION TIME (min.)

E18. 8. Ge1 electrophoretic analysis of prothrombin activation by the native purifled venom activator. $3 \mu \mathrm{M}$ prothrombin was activated in a reaction mixture containing $50 \mathrm{mM} T r 1 \mathrm{~s}-\mathrm{HCl}$ ( $\mathrm{pH} 7.9$ ), $175 \mathrm{mM} \mathrm{NaCl}$, $20 \mu \mathrm{M} \mathrm{I} 2581,5 \mathrm{mM} \mathrm{CaCl}, 0.1 \mu \mathrm{g} / \mathrm{ml}$ purifted activator, and $50 \mu \mathrm{M}$ phosphol1pid ( $25 \%$ PS/ $75 \%$ PC) at $37{ }^{\circ} \mathrm{C}$. At the time interval indicated, allquots $(100 \mu 1)$ of this reaction mixture were added to $37.5 \mu 1$ of gel buffer contalning $250 \mathrm{mM}$ Tr1s-HCl (pH 6.9), 5\% SDS, $40 \mu \mathrm{M}$ Lodoacetamide, and $50 \%$ (v/v) glycerol or to $12.5 \mu 1$ of $2 \mathrm{mM}$ dansy1-Glu-Gly-Arg-CH, $\mathrm{Cl}$ in 10 mM $\mathrm{HCl}$. The latter samples were 1ncubated for $15 \mathrm{~min}$ at $37{ }^{\circ} \mathrm{C}$, and then $37.5 \mu 1$ of the gel buffer described above were added. Prlor to electrophorests, the samples were kept for $1 \mathrm{~h}$ at $37^{\circ} \mathrm{C}$ durling which per1od $5 \%$ (v/v) B-mercaptoethanol was present in the disulfide-reduced samples. After electrophoresis, the gels were stalned wh Coomasale Brilliant Blue $R-250$ ( $A$ and $B$ ) or transiliminated with long wave ultraviolet light and photographed using a yellow fllter and Polarold type 55 fIIm (C and D). Non-reduced samples are shown $1 \mathrm{n} A$ and $C$, whereas reduced samples are shown in $B$ and $D$. The lanes at the far right of the Coomassie Bluestained gels contaln a reference mixture of prothrombin and activation products. PT = prothrombin, PTI prethrombin $1, F 1.2=$ fragment $1.2, \mathrm{PT} 2=$ prethrombin $2, T=$ thrombin, $\mathbb{T}_{\mathbb{B}}=B$-cha1n of thromb1n and $F 1=$ fragment 1 . 
reactions of thrombin on prothrombln. The non-reduced gel shows that thrombin ts the major reaction product and that small amounts of prethrombin 1 and 1 agment 1 are formed (F1g. 8A). On the reduced ge1, the pattern 1 somewhat different (F1g. 8B). The Intensity of the protein band corresponding to thrombin (the thrombin B-chatn) 1 s 1ncreased, whereas the intensttles of the prothrombin and prethrombin 1 bands are decreased. This indlcates that, in addition to thrombin, melzothrombin and melzothrombin des-fragment 1 are also formed. The presence of melzathrombin in the prothrombin activation mlxtures becomes even more clear upon electrophorests of reaction allquots that were treated with dansyl-Glu-Gly-Arg$\mathrm{CH}_{2} \mathrm{Cl}$. At high concentrations, this inhubitor alkylates the histidine of the catalytic triad of thrombin, melzothrombln, and melzothrombin des-fragment 1 (22). Due to the fluorescent properties of dansy1-Glu-Gly$\mathrm{Arg}-\mathrm{CH}_{2} \mathrm{Cl}$, the protelns that 1 ncorporate this 1 nhibitor can be visualized on the gel after electrophoresis (19). Indeed, $\mathbb{F} 1 \mathrm{~g}$. $8 \mathrm{C}$ shows that, $\mathbb{1 n}$ aliquots of reaction mlxtures in which prothrombin 13 activated by the venom activator, dansyl-Glu-Gly-Arg-CH $2 \mathrm{Cl}$ incorporates into proteins co-migrating with prothrombin, prethrombin 1 , and thrombin. Upon reduction al1 fiuorescent label co-migrates with the B-chain of thrombin which Indicates that the fluorescent protelins on the non-reduced gels are Indeed melzothrombin, meizothrombin des fragment 1 and thrombin (Fig. 8D).

For the NaSCN-treated activator, the cleavage pattern is somewhat different. In addition to melzothrombin, melzothrombin des-fragment 1 , and throublin, there are considerable anounts of prethrombin 2 visible on the gel ( $\mathrm{fg}$. 9). With respect to the comparison of the NaSCN-treated and the native venom activator with Factor Xa and the Factor Xa-Va complex, it is interesting to note that prethromblin 2 is also produced in large amounts when factor Xa is allowed to activate prothrombin in the absence of Factor Va (1).

Deteruination of $y$-carboxyglutamic acid residues in the venom prothrombin Activator. In a prevlous paper, we have shown that the prothrombin activator from the venom of Notechls scutatus scutatus contains several $p$-carboxyglutanic acid (Gla) residues (9). Therefore, we decided to test whether the activator from oxyuranus scutellatus also contalns such residues. The Gla content of the venom activator was determined by high performance 1quid chromatography according to Kuwada and Katayama (23). As a contro1, 
A

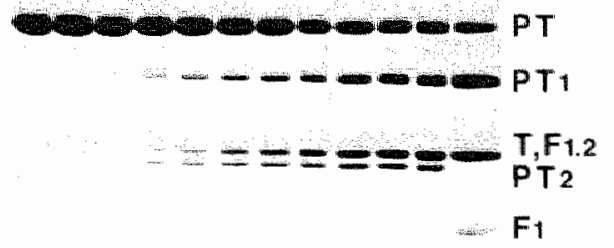

B

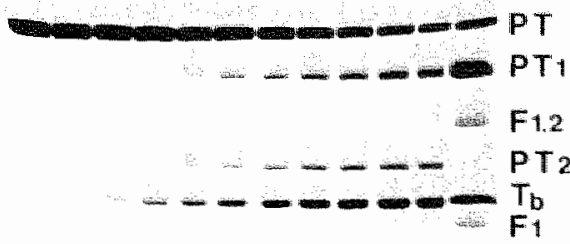

$\begin{array}{lllllllll}0 & 2 & 4 & 7 & 10 & 15 & 20 & 30 & 405060\end{array}$

INCUBATION TIME (min.) $\begin{array}{llllllllll}0 & 2 & 4 & 7 & 10 & 20 & 30 & 40 & 5060\end{array}$ INCUBATION TIME (min.)

FIg. 9. Ge1 electrophoretic analysis of prothrombin activation by the NaSCN-treated venom activator. The purifled venom activator $(67.5$ $\mu \mathrm{g} / \mathrm{ml}$ ) was incubated for $1.5 \mathrm{~h}$ at $37{ }^{\circ} \mathrm{C}$ in the presence of $0.8 \mathrm{M}$ NaSCN, and was subsequently dialyzed against 50 mM Trls-HCl (pH 7.9) and $175 \mathrm{mM} \mathrm{NaCl}$ to remove the NaSCN. Prothrombin $(6.25 \mu \mathrm{M})$ was activated by $56.7 \mu \mathrm{g} / \mathrm{ml}$ of the NaSCN-treated and dialyzed venom activator in a reaction mixture containing 50 mM Tris-HCl (pH 7.9), $175 \mathrm{mM} \mathrm{NaCl}, 5 \mathrm{mM} \mathrm{CaCl}, 50 \mu \mathrm{M}$ phospholiplds (25\% PS/75\% PC), and $20 \mu \mathrm{M}$ 12581. Gel electrophoretic analysis of prothrombin activation was further carried out as described in the legend to Fig. 8 .

we also measured the content of Gla resldues $\mathbb{1}$ n Factor Xa. The chromatograms of alkaline hydrolysates of Factor Xa and of the venom prothrombin activator from oxyuranus scutellatus are shown in Fig " 10 . The peaks corresponding to Gla and Glu are indicated in the figure. The amino actds eluting at 13.88 min (Fig. $10 A$ ) and $13.45 \mathrm{mln}$ (Fig. 1OB) are ldentifled as Gla since they are absent in actd hydrolysates $(16 \mathrm{~h}$ in $6 \mathrm{~N}$ $\mathrm{HCl}$ at $100{ }^{\circ} \mathrm{C}$ in vacuo) of Gla contalining proteins. Factor $X_{a}$ had a Gla/(G1utGIn) ratio of 0.42 which corresponds to about 11 Gla residues/mole since the (GlutGIn) content of Factor Xa 1s 25/mole (24). This value is in cloge agrement with that reported in the literature (12 Gla regldues/ Factor Xa, cf.ref. 25). The Gla/(GlutGln) ratlo observed for the venom activator was 0.042 . Although conslderably lower than that of factor Xa this is not surpristing since the molecular welght of the venom activator 1 s about $7 \mathrm{x}$ higher than that of Factor Xa. Since the (GIutGln) content of the venom activator is not known, it is not possible to calculate the exact number of Gla residues. Considering the large molecular weight of the activator, it is, however, likely that the venom activator contalns 


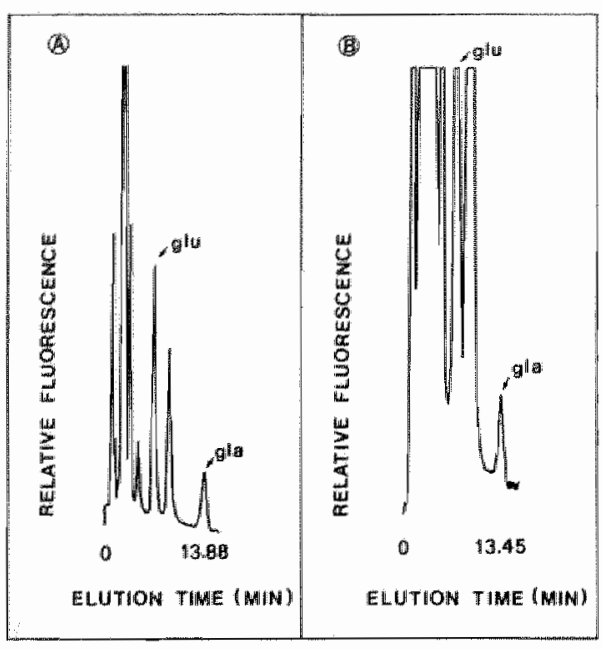

Fig. 10. HPLC determination of y-carboxyglutamic acld residues in the venom prothromin activator from oxyuranus scutellatus. The presence of $y$-carboxyglutamic acld (Gla) and glutanic acid (Glu) residues in alkaline hydrolysates of Factor Xa. (EIg. 10A) or the venom activator (F1g. 10B) were determined on a Nucleos11-5SB column according to the method of Kuwada and Katayama (23). The peaks corresponding with the elution of Glu and Gla are identifled $\mathbb{i n}$ the figure.

sufflclent Gla restdues to support $\mathrm{Ca}^{2+}$-dependent binding of the activator to negatively charged phospholipid surfaces.

Comparison of functional properties of prothrombin activators in venoms from Australlan elapld snakes. It is generally belleved that the coagulant action of Australian elapid venoms is mainly due to the presence of prothrombin activators that require cofactors for their activity (27). on $1 \mathrm{y}$ the venom activators from Notechis scutatus scutatus and oxyuranus scutellatus have so far been studled in suffictent detall to allow conclusions regarding their mode of action tn prothrombin activation. To test whether the other Australian elapid venoms contaln a Notechis-like prothrombin activator that is stimulated by both phospholipids and Factor Va or whether they contain an Oxyuranus-11ke prothrombin activator that is at Imulated by phospholiplds and that has its own Factor Va-11ke cofactor, we have compared the prothrombin-converting propertles of a number of commerclally avallable venoms (Table $v$ ). The experiment reported in this table was carried out as follows. Amounts of venom from the different snakes were taken that gave approximately the same rate of prothrombin activation without added accessory components. The stimulatory effect of phosphollpld and phosphollpld plus Factor $\mathrm{Va}$ on the venom activity was measured to determine the cofactor dependence of venom-catalyzed prothrombin activation. Finally, the venoms were treated with NaSCN to test 
Table V

\section{Effects of phospholiplds and Factor Va on prothrombin activation by various snake venoms}

Prothrombin activation was determined in a reaction mixture contalning 0.5 4 prothrombin, approprlate dilutions of crude venon, 5 mu CaCl, with or without $50 \mu \mathrm{M}$ phosphollpid (PL) or $50 \mu \mathrm{M}$ phosphollpid plus $5 \mathrm{nM}$ Factor Wa (Va) in $50 \mathrm{mM}$ TrLs ( $\mathrm{pH} 7.9), 175 \mathrm{mM} \mathrm{NaCl}$ and $0.5 \mathrm{mg} / \mathrm{ml}$ HSA. The phospholipld vesicles contained $25 \%$ PS and $75 \%$ PC. Prothrombin activation was determined as described in the experimental procedures. The rate of prothrombin activation measured in the absence of phospholipids and Factor Va is expressed as nanomoles of prothrombin activated per min per mg of crude venom. The stimulation by PL or PL $+V a$ is obtained by comparison with the rate of prothrombin activation in the absence of accessory components which for each Individual venom was arbitrarily taken as 1 .

\begin{tabular}{|c|c|c|c|}
\hline \multirow{2}{*}{ Venom } & \multirow{2}{*}{$\begin{array}{l}\text { nmo } 1 \text { prothrombin } \\
\text { actived/min/mg venom } \\
\text { without PL and va }\end{array}$} & \multicolumn{2}{|c|}{ Stimulation Factor } \\
\hline & & PL & $\mathrm{PL}+\mathrm{Va}$ \\
\hline Notechis scutatus scutatus & $0.27 \times 10^{-3}$ & 7570 & $34.2 \times 10^{6}$ \\
\hline Notech1s ater niger & $0.24 \times 10^{-3}$ & 1453 & $5.4 \times 10^{6}$ \\
\hline Notechis ater humphreysi & $0.14 \times 10^{-3}$ & 6422 & $13.5 \times 10^{6}$ \\
\hline Tropldechts carinatus & $0.08 \times 10^{-3}$ & 3260 & $9.1 \times 10^{6}$ \\
\hline Pseudechis porphyriacus & $0.11 \times 10^{-3}$ & 1443 & $2.7 \times 1.0^{6}$ \\
\hline Hoplocephalus stephensit & $0.07 \times 10^{-3}$ & 400 & $6.3 \times 10^{6}$ \\
\hline Oxyuranus inlcroleptdotus & 0.48 & 527 & $7 \mathbb{1}$ \\
\hline Oxyuranus scutellatus & 2.13 & 448 & 456 \\
\hline Pseudonaja textlils textilis & 11.4 & 257 & 297 \\
\hline Dispholidus typus & 241 & 0.7 & 0.7 \\
\hline Echis carinatus & 19 & 0.8 & 1. .4 \\
\hline
\end{tabular}

whether they lost prothrombin-converting activity that could be restored with Factor Va, a property which would indlcate that the venom activator, like Oxyuranus, contalns a Factor Va-11ke cofactor. Table V shows that the Australlan elapld venoms can indeed be divided in two groups: one group containing a Notechis-11ke prothrombln activator (Notechis scutatus scur 
tatus, Motechis ater niger, Notechis ater humpheys1, Tropidechis carlnatus, Patudechs porphyriacus, and Hoplocephalus stephensil) which requires phospholiptds plus $\mathrm{Ca}^{2+}$ and pactor Va and a second group of oxyuranus-11ke prothrombin activators (Oxyuranus scutellatus, oxyuranus microlepldotus and Pseudonaja text111s text1118) which require phospholiplds plus ca ${ }^{2+}$ but are not atimulated by factor Va. The venoms of this group lose their abillty to actiwate prothrombin upon NaSCN treatment, and rapld prothrombin activation by the NaSCN-treated venom becomes dependent upon the presence of Factor Va (Table VI). This Indlcates that this group of venoms indeed contalns a prothrombin activator comprised of a catalytic unit and a Factor Va-1ike cofactor. For comparison, the data obtalned with a number of venoms not belonging to the Australian Elapldae are also given in Tables $V$ and VI. The well-known prothrombin activators from Echls carlnatus and Dispholidus typus are not affected by the accessory components of the prothrombinase compllex.

Table VI

\section{Effect of Factor Va on prothrombin activation by crude venoms treated with NaSCM}

Crude venoms of varlous snakes were Incubated at $37{ }^{\circ} \mathrm{C}$ for 24 hrs at 0.1 $\mathrm{mg} / \mathrm{ml}$ In $50 \mathrm{mM} \mathrm{Tris}(\mathrm{pH} \mathrm{7.9)}, 175 \mathrm{maCl}$, wh or thout $0.8 \mathrm{M} \mathrm{NaSCN}$. The prothrombin-converting activity of the non-treated and NaSCN-treated venoms were determined in the presence of phospholipld with and without Factor Va as described in the expertmental procedures. " $c^{*}$ represents the ratio of the stimulatory effect of Factor $V a$ on the rate of prothrombin activation by the NaSCN-treated and non-treated wenom.

\begin{tabular}{|c|c|c|c|}
\hline Venom & c & Venom & c \\
\hline Notechis scutatus acutatus & 1.3 & Oxyuranus scutellatus & 1933 \\
\hline Notechlis ater niger & 1.3 & oxyuranus microleptdotus & 981 \\
\hline Notechis ater humphreysi & 1.1 & Pseudonaja textilis text111s & 262 \\
\hline Troptdechls cartnatus & 1.2 & & \\
\hline Pseudechls porphyrtacus & 1.1 & Dispholldus typus & 2.6 \\
\hline Hoplocephalus stephensti & $\mathbf{n} \cdot d \cdot * *$ & Echis carinatus & 1.9 \\
\hline
\end{tabular}

* (Vothrombin activationtVa/ prothrombin activation-Va) NaSCN-treated venom

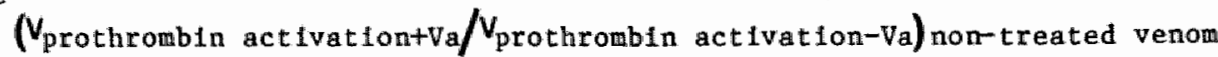

* The prothrombin-converting activity was completely lost upon NaSCN treatment and was not restorable with Factor Va 


\section{DISCUSSION}

Prothrombin activators from the venoms of the Australlan Elapidae share many properties with Factor Xa, the physiological activator of prothrombin. One of the mafor simllarities with Factor Xa concerns the observation that the prothrombin-converting activity of the venom activators can also be stimulated by the accessory components (phospholiplds and/or Factor Va) of the prothrombinase complex. In this paper, we have described the purification and the structural and functional characterization of the prothrombln activator from the venom of oxyuranus scutellatus (Talpan snake). The prothrombin-converting activity of this venom activator ls drastically enhanced by the presence of phospholiplds plus $\mathrm{Ca}^{2+}$ but is not affected by Factor Va. The native activator is a large protein molecule With an apparent molecular weight of about 300,000 which appears to consist of a catalytic unit of $M_{r} 57,000$ bearing the active site and a cofactor part with a Factor Va-11ke function, which has an apparent $M_{r}$ of 220,000 . Walker et a1. (11) suggested that the venom prothrombin activator from Oxyuranus scutellatus scutellatus may be comprised of elther two enzymes or a single enzyme bearing two catalytic sites with distinct activities. Our data show that the venom activator is actual1y one enzyme that can exist in two forms, 1 .e. one form with and one form without protein cofactor*

Several observations reported in this paper indicate that the mode of action of this cofactor part in venom-catalyzed prothrombin activation is sinflar to that of Factor Wa in prothrombin activation by Factor Xa. The catalytic properties of the native venon activator resemble those of the Factor Xa-Va complex. Both catalyze prothrombin activation with a high Vmax and for both enzyme complexes, the $\mathrm{Km}$ for prothrombin $\mathrm{Ig} \mathrm{high}$. The $\mathrm{km}$ decreases conslderably when negatively charged phosphollplds are introduced as part of the prothrombin-activating complex. The native activator also shares the property of the Factor Xa-Va complex $1 \mathrm{n}$ that low Km valueg for prothromb1n are also measured when phosphollpids with a low affintty for prothrombin (1.e. membranes wth a low mole percentage of ps) are used as procoagulant surface. Detalled kinetic studies of prothrombin activation by the Factor Xa-Va complex have shown that this phenomenon is caused by Factor va (5). 
The main apport for the hypothesis that the venom prothrombin activator from oxyrang scutellatug is a multimeric protein consisting of a catalytuc unte assoclated wth a Factor Va-like cofactor came from an expertment in which the native activator was subjected to prolonged gradfent gel electrophoresis under non-denaturing conditions. In this experfment, the catalytic and cofactor parts of the venom activator were Beparated from each other and appeared in different parts of the gel. The catalytic unit migrated at a molecular welght of 57,000 and had a low prothrombln-converting activity and a high anddolytic activity. The prothrombin-converting activity of this low $M_{r}$ catalytic unit could be restored with bovine Factor Va and wh a protein that could be eluted from the gradlent gel, which had an apparent molecular wefght of 220,000 . This protein 1 presumably the Factor Vame cofactor part af the venom activator.

The native venom activator also structurally resembles the Factor Xa-Va complex. The catalytic unit of the venom activator consists of two polypeptide chatns of $M_{r} 30,000$ linked together via a disulfide bridge. Factor Xa is also a two-chain molecule. It consists of a heavy chain of $\mathrm{M}_{r} 30,000$ which bears the catalytic site and which is linked via a disulfide bridge to a light chaln of $M_{r} 15,000$. Gel electrophoretlc analysis of the purtfled venom activator shows two other major protein bands with apparent molecular weights of 110,000 and 80,000 . They 11kely comprise the cofactor part of the venom activator and may structurally resemble Factor Va. Bowine Factor Va hag a molecular weight of 180,000 and conslsts of two subunits of ${ }_{r}$ 115,000 and $73,000(26)$. The structural features of the venom prothrombin activator led us to the hypothetical model shown In Fig. 11. We propose that the Oxyuranus activator consists of a Factor Xa-11ke part consisting of two subunits of $M_{r} 30,000$ and a Factor Va-11ke part of about $M_{r} 220,000$ that 1 s composed of two polypeptide chafns of approximately $M_{r} 110,000$ and 80,000 . Slnce the apparent molecular welghts of the native activator $(300,000)$ and the cofactor part $(220,000)$ are somewhat higher than the sum of the Individual subunlts, it is possible that some low $M_{r}$ subunits that may have escaped our attention are also part of the native activator. The hypothet lcal model does not explain the chemlcal or physlcal nature of the forces that are responsible for the association of the subunits within the cofactor part. It is possible that in a fraction of the activator 


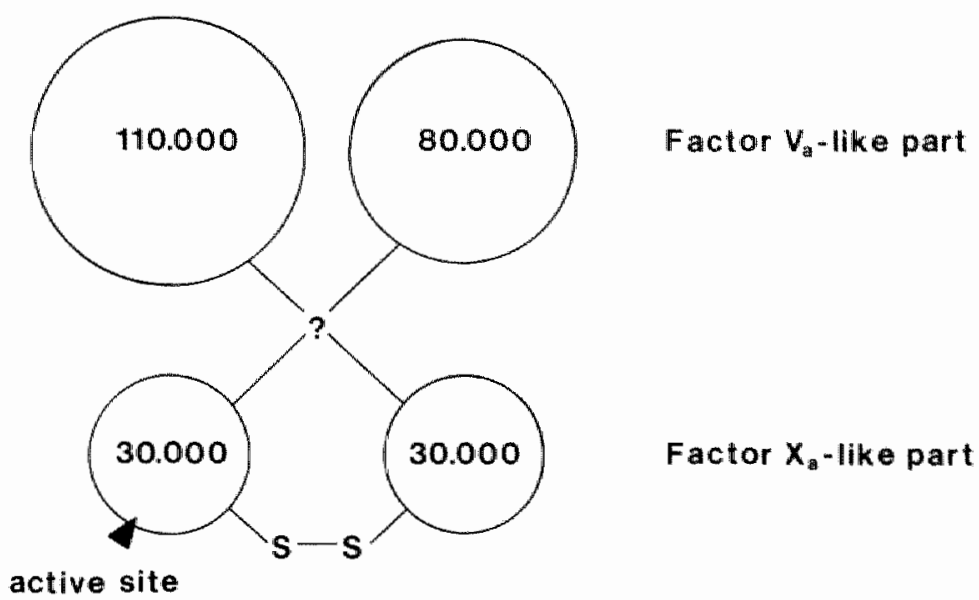

Fig. 11. Hypothetical mode1 for the venom prothrombin activator from oxyuranus scutellatus.

molecules, these subunits are held together by a disulfide bridge since on non-reduced $\operatorname{SDS}$ gels a subunit of $\mathrm{M}_{r} 220,000$ is observed. Upon reduction, this band disappears and dissoclates Into subuntits that co-migrate wh the $M_{r} 110,000$ and 80,000 polypeptides. The polypeptide subunits that we abserved to be present in the prothrombin activator preparation from Oxyranus scutellatus was somewhat different from the subuntt composttion of the activator 1solated from Oxyuranus scutellatus scutellatus by Walker et al. (11). They reported that their activator preparation contains two bands Wth molecular weights corresponding to 220,000 and 160,000 which upon reduction separate into two bands of $M_{F} 105,000$ and 76,000 . We did not observe a $M_{r} 160,000$ subunit on non-reduced gels, whereas Walker et al. (11) did not identify the presence of the weakly stalning $M_{r} 60,000$ subundt $\left(M_{r} 30,000\right.$ on reduced gels) that comtalns the catalytic site of the activator. The discrepancy with regard to the $M_{r} 160,000$ subumit on the non-reduced SDS gel may be due to the use of venom preparations from different subspecies of Dxyuranus scutellatus or to the earlier mentioned possiblity of partial reduction of disulfide bridges that may have occurred In our preparation.

Finaly, it is important to mention that the venom activator, 11ke Factor Xa, contalins $p$-carboxyglutamic acld residues. Although thelr exact number ls not known, it is likely that suffictent residues are present to support 
the $\mathrm{Ca}^{2+}$-dependent binding of the venom activator to negatively charged phospholiplds. Such binding would explain their stimulatory effect on venom-catalyzed prothrombln activation as well as on the corresponding phospholipld-dependent decrease in the Km for prothrombin it is $11 k e l y$ that these effects are caused by simultaneous binding of the venom activator and the substrate prothrowin to the phosphollpld surface. Such almultaneous bindling will promote the formation of the enzyme-substrate complex and enhance the rate of prothrombin actuation (cf. refs. 1 and 5 for a detalled description of such a model for phosphollpid involvenent in prothrombin activation by Factor Xa).

The presence of a complex prothrombin activator in a snake venom is not typlcal for oxyuranus scutellatus. In Table VI $1 t$ is shown that the catalytic propertles of a number of other Australlan Elapldae (Pseudonaja text11s text11is and oxyuranus microlepldotus) show a high degree of Billarity wh the activator from oxyuranus scutellatus. These venoms presumably also contain a multimeric prothrombin activator comprised of an enzyme assoclated with a Factor Va-like cofactor that greatly enhances the catalytio capactey of these venom activators.

Acknowledgements. We thank Dr. Guldo Tans for his helpful criticlams. Berry Soute is acknowledged for the determination of $\gamma$-carboxyglutamic acld, Coen van dex Gugten for his assistance in preparation of the figures, and Martet Molenaar-v.d.Voort for typing the manuscript. AB Kabll Diagnostica kindly provlded part of the chromogenlc substrates used in this gitudy.

\section{REFERENCES}

1. Rosing, J., Tans, G., Govers-Riemslag, J.W.P., Zwaal, R.F.A., and Hemker, H.G. (1980) J. Blo1. Chem. 255, 274-283.

2. Neshe1m, M.E., Taswe11, J.B., and Mann, K.G. (1979) J. Blol. Chem. 254, 10952-10962.

3. Lindhout, T., Govers-Rlemslag, J.W.P., van de Waart, P., Hewker, H.C., and Rosing, J. (1982) Blochemistry 21, 5495-5502.

4. Pusey, M.L., and Nelsestuen, G.L. (19B3) Blocher. Blophys. Res. Commun. $114,526-532$.

5. van RiJn, J.L.M.L., Govers-Rlemslag, J.W.P., Zwaal, R.F.A., and Rosing, J. (1984) Blochemfitry $23,4557-4564$. 
6. Kornalik, F., and Blomback, B. (1975) Thromb. Res. 6, 53-63.

7. Morita, T., Iwanaga, S., and Suzuki, T. (1976) J. Biochem. (Tokyo) 79, $1089-1108$.

8. Jobin, F., and Esnouf, M.P. (1966) Nature $211,873-875$.

9. Tans, G., Govers-Riemslag, J.W..P., van Rifn, J.L.M.L., and Rosing, J. (1985) J. Biol. Chem. 260, 9366-9372.

10. Plrkle, H., McIntosh, M*, Theodor, I., and Vernon, S. (1972) Thromb. Res. 1, 559-568.

11. Walker, F.J., Owen, W.G., and Esmon, C.T. (1980) Biochemistry 19, 1020-1023.

12. Owen, W.G., Esmon, C.T., and Jackson, C.M. (1974) J. Bilo1. Chem. 249, $594-605$.

13. Fujlkawa, K., Legaz, M.E., and Davie, E.W. (1972) Biochemistry 11, $4882-4891$.

14. Chase, T., and Shaw, E. (1969) Blochemfstry 8, 2212-2224.

15. Smith, R.L. (1973) J. B101. Chem. 248, 2418-2423.

16. Sedmak, J.J., and Grossberg, S.E. (1977) Ana1. Blochem. 79, 544-552.

17. Confurius, P., and Zwaal, R.F.A. (1977) Bloch1m. Blophys. Acta 488, $36-42$.

18. Buttcher, C.J.E., van Gent, C.M., and Pries, C. (1961) Anal. Ch1m. Actea $24,203-207$.

19. Rosing, J., Zwaal, R.F.A., and Tans, G. (1986) J. Biol. Chem. 26I, 4224-4228.

20. Laemm11, U.K. (1970) Nature 227, 680-685.

21. Elsenthal, R., and Cornish-Bowden, A. (1974) Blochem. J. 139, 715-720.

22. Kettner, C.A., and Shaw, E.N. (1981) Methods Enzymo1. 80, 826-842.

23. Kuwada, M., and Katayama, K. (1983) Ana1. Blochem. 131, 173-179.

24. Jackson, C.M., and Nemerson, Y. (1980) Annu. Rev. Biochen. 49, 765-811.

25. Fernlund, P., and Stenflo, J. (1982) J. B101. Chem. 257, 12170-12179.

26. Esmon, C.T. (1979) J. B101. Chem. 254, 964-973.

27. Marshall, L.R., and Hermann, R.P. (1983) Thromb. Haemostasis 50, 707-711. 

CHAPTER IV

PLATELET PROCOAGULANT PROPERTIES STUDIED WITH SNAKE VENOM PROTHROMBIN ACTYWATORS

\section{SUMMARY}

Purlfied snake venom prothrombin activators were used to probe the procoagulant properties of platelet membranes. Human platelets were able to stimulate prothrombin activation by the venom activators from oxyuramus scutellatus and Notechis scutatus, whereas the prothrombin activator from Echis cartnatus was not affected by the presence of platelets. The prothrombin-converting activity of platelets was further studled with the venom activator from oxyuranus scutellatus and with the Factor Xa-Va complex as prothrombin-activating enzymes. Stimulation of platelets with collagen, collagen plus thrombin, or with the Ca-lonophore A23187 resulted In a considerable increase of platelet prothrombin-converting activity probed with the Factor Xa-Va complex, as well as with the prothrombin activator from oxyuranus sicutellatus. The stimulatory effect of activated platelets on the rates of prothrombin activation by oxyuranus scutellatus was similar to that determined for Factor Xa-Va-catalyzed prothrombin activation. Compared to non-stimulated platelets, platelets stimulated with thrombln plus collagen exposed twenty times more procoagulant sites for the Factor Xa-Va complex, as well as for the venom activator from Oxyuranus scutellatus. The actual number of procoagulant sttes per platelet determined with the Factor Xa-Va complex was in close agreenent with the number of sites determined with the venom activator. The time course of appearance of procoagulant activity during platelet stlmulation by collagen plus thrombin was also comparable for both actlvetor complexes. PhosphoIipase $A_{2}$ treatment of stimulated platelets resulted in an almost complete loss of their ability to stimulate prothrombin activation by the enzyme from oxyuranus scutellatus or by the Factor Xa-Va complex. The findings presented in this paper suggest that a) the Factor Xa-Va complex and the prothrombin activator from oxyuranus scutellatus recognize the same 
procoagulant ites on both stimulated and unstimulated platelets, and b) negatively charged phosphollplds are essential components of these procoagulant sitee.

\section{INTRODUCTION}

Blood platelets play an important role in the interactions and reactions between coagulation factors that are essential for hemostatic plug formation. It has been shown that activated platelets stlmulate prothrombin and Factor $X$ activation $(1,2)$. Several studles indicate that platelets have the ablifty to bind the partlclpating coagulation factors, thus promoting the assembly of the prothrombin- and Factor X-activating complexes and enhancing the rate of coagulation factor activation (3-6). The chemical nature of the platelet procoagulant sltes $1 \mathrm{~s}$ still a matter of debate. It has been proposied that speciflc protein receptors may participate in the blinding of coagulation factors to the platelet plasma membrane (7-9). However, at present there is no direct evidence for the existence of such protelns. Another suggestion is that negatively charged phospholipids, especially phosphatidylserine, are involved in the binding of coagulation factors to the platelet membrane $(10,11)$. This hypothesis is based on two observations: 1) In vitro prothrombin and Factor $X$ activation $1 \mathrm{~s}$ stimulated by membrane surfaces that contain negatively charged phospholiplds (12), and 2) activation of platelets leads to exposure of phosphatidylserine restdues in the outer leaflet of the platelet plasma membrane with a concomtant increase of platelet prothrombin- and Factor $X$-converting activity $(6,10)$. It should be emphasized, however, that these two mode1s do not exclude each other, and that $1 \mathrm{t}$ is possible that both protein and 11 pid components may function $\mathbb{1}$ the procoagulant sites that are involved in prothrombln and Factor $X$ activation.

In an attempt to gain more lnsight in the nature of these binding sttes, we have used purifled snake venom prothrombin activators. Venom activators from different snake spectes have widely different properties in prothrombin activation (13). It has been shown that there is a group of venom activators that has no cofactor requirement $(14,15)$, whereas there are snake venoms with a prothrombln activator, which is stimulated either 
by phospholiplds alone $(16,17)$ or by phosphollpids and Factor Va $(18,19)$. In the present study, we show that prothrombin activation by the venom activators from Notechis scutatus (Tiger Snake) and oxyuramus scutellatus (Talpan Snake) is strongly stimulated by blood platelets. Since the venom activator from oxyuranus scutellatus is only stimulated by negatively charged phospholiplds, and not by Factor Va, it was studled in wore deta11, and 1 ts platelet-dependent prothrombin-converting activity was compared wth that of the Factor Xa-Va complex. Our results indicate that the functional binding sites for the oxyuranus scutellatus activator on platelets are the same sites, which particlpate in prothrombin activation by the Factor Xa-Va complex, and that negatively charged phosphollplds are an essentlal component of these sites.

MATERIALS AND METHODS

Reagents. S2238 was purchased from AB Kabl Diagnost1ca. Dansy1-Glu-Gly$\mathrm{Arg}-\mathrm{CH}_{2} \mathrm{Cl}$ and the calclum lonophore $\mathrm{A} 23187$ were obtalned from Calblochem. P-NPGB was from ICN Nutritional Biochemicals. DEAE-Sephadex A-50, QAE-Sephadex A-50, SP-Sephadex C-50, Sephadex G-100 and Sephadex G-200 were products of pharmacla. Ovalbumin, human serum albumin (fatty acid free), benzamidine-HCl, 1,2-dioleoy1-sn-glycero-3-phosphocholine (PC) and lyophilized crude suake venoms of Notechls scutatus and oxyuranus scutellatus were obtalned from Sigma. Ecarin, the purifled prothrombin activator from Echis carinatus venom, and $\mathrm{CH}_{3} \mathrm{OCO}-\mathrm{D}-\mathrm{CHG}-\mathrm{G} 1 \mathrm{y}-\mathrm{Arg}-\mathrm{pNA} . \mathrm{AcOH}$, a chromogenic substrate for Factor Xa, were purchased from Pentapharm Ltd. Naja naja venom was from Koch Light. Horse tendon collagen was purchased from Hormon Chemfe. Teflon-coated magnet1c stirring bars, $7 \times 2$ mol, were from Bel-Art Products Pequannock, N.J.. All reagents were of the highegt grade comerclally available.

Prateins. The prothrombln activators from Motechis scutatus and 0xyuranus scutellatus were purifled from their respective crude venoms as described ear11er $(17,19)$. Phospholipase $A_{2}$ was purifled from Naja naja venom by the method of Zwal et al. (20). Bovine prothrombln was purified as described by owen et al. (21). Bovine Factor Xa was purifled according to the method 
of Tullkawa et al. (22). Thrombin was purifled as described before (23). Factor and Factor Va were obtalned ag descrtbed by lindhout et a1 (24). The proteln preparations were stored at $-80^{\circ} \mathrm{C}$ in $50 \mathrm{mM} \operatorname{Tr} 1 \mathrm{~s}-\mathrm{HCl}$ ( $\mathrm{pH} 7.9$ ), $175 \mathrm{mH}$ NaC1, $0.5 \mathrm{mg} / \mathrm{m} 1$ human serum album $1 \mathrm{n}$. Factor Va was stored in the same buffer contalning $5 \mathrm{mM} \mathrm{CaCl} 2$. Phosphollpase $A_{2}$ was stared $1 \mathrm{n} 50 \%$ glycerol at $-20^{\circ} \mathrm{C}$.

Protein concentrations. The concentrations of thrombin (25) and Factor Xa (26) were determined by active site titration with $\mathrm{p}-\mathrm{NPGB}$. Prothrombin concentrations were obtained fith the same method after complete activation with Echls carinatus venom. Factor Va concentratlons were determined by kinetic analysis as described by Lindhout et al. (24). The concentration of the purffled activator from Notechis scutatus was calculated from a protein determination according to Lowry et al. (27), using bovine serum albumin as a standard, and assuming a molecular welght of 54,000 for the venom activator (19). The concentration of the purifled oxyuranus scutellatus actlvator was established by titration with dansyl-Glu-Gly-Arg-CH, $\mathrm{Cl}$ (cf. ref. 28), an 1rreversible inhibitor of Factor Xa-1ike enzymes. The concentration of Oxyuranus scutellatus obtalned in this way correlated we11 wth the concentration calculated from a proteln determination according to Sedmak et al. (29), and using a molecular weight of 300,000 for the venom activator (17).

Phospholipids and phosphollpid vestcle preparations. 1,2-D1oleoyl-sn-g1ycero-3-phosphoserine (PS) was prepared from PC by enzymatic synthesis (30). single bllayer phosphollpid vestcles were prepared by sonication of a mixture of $10 \%$ PS and $90 \%$ PC (mol/mol) as described earlier (23). Phospholipld concentrations were determined by phosphate analysis (31).

Isolation of platelets. Human platelets from healthy volunteers were isolated by differential centrifugation as described before (6). No loss of platelet procoagulant activity was found for at least 15 hours when platelets were kept at room temperature in a buffer containing $136 \mathrm{mM}$ NaCl, 2.68 $\mathrm{mM} \mathrm{KCl}, 2 \mathrm{mM} \mathrm{MgCl}_{2}, 10 \mathrm{mM}$ HEPES, $5 \mathrm{mM}$ glucose, and $0.5 \mathrm{mg} / \mathrm{ml}$ human serum albumin ( $\mathrm{pH} 7.5)$. Platelet concentrations were measured with a Coulter counter (Coulter Electronics). 
Platelet stimulation and determination of prothrombin-converting activity. The effect of platelets in prothrombln activation was deterined in plastlc flat-bottom tubes $(2 \mathrm{ml})$, in which the reaction mixtures were stirred at 350 rpm th tefion stirring bars. To a reaction tube, contalning 292.5 wl of a platelet suspension, $13 \mu 1$ of 75 miM $\mathrm{CaCl}_{2}$ were added. The tube content was warmed and stirred at $37{ }^{\circ} \mathrm{C}$. Platelet activation was started after 5 minutes by addition of a platelet stimulator, resulting in a final volume of $325 \mathrm{\mu l}$ and a $\mathrm{CaCl}_{2}$ concentration of $3 \mathrm{mM}$. After a variable time period, referred to as platelet activation time, the platelet prothrombin-converting activity was determined as described below.

Assay of platelet activity in prothrombin activation. 30 to 120 seconds before measuring the effect of platelets in prothrombin activation, $50 \mu 1$ of prothrombin activator (Factor Xa with or without Factor Va "or venom activator with or without Factor Va) were added to the platelet suspension. Prothrombin activation was started by adding $125 \mathrm{pl}$ of prewarmed prothrombin in $50 \mathrm{mM}$ Tris-HC1 (pH 7.9), $175 \mathrm{mM} \mathrm{NaCl}, 15.2 \mathrm{mM} \mathrm{CaCl}$, and 0.5 $\mathrm{mg} / \mathrm{ml}$ human serum albumin. The flnal reaction mixture $(500 \mu 1)$ contalned 20 $\mathrm{mM}$ Trls, $6 \mathrm{mM}$ Hepes, $150 \mathrm{mM} \mathrm{NaC1}, 1.6 \mathrm{mM} \mathrm{KCl}, 1.2 \mathrm{mM} \mathrm{MgCl}, 6 \mathrm{mM} \mathrm{CaCl}_{2}, 2.9$ $\mathrm{mM}$ glucose, $0.5 \mathrm{mg} / \mathrm{ml}$ human serum albumln at $\mathrm{pH} 7.9$, and amount 8 of platelets, prothrombin, prothrombin activator, and Factor Va as indfcated in the legends to the tables and figures. Aliquots (usually 5 to $10 \mu 1$ ) were taken from the reaction mixture 10 and 20 seconds after the onset of prothrombin activation. These allquots were transferred to cuvettes, containing $50 \mathrm{mM}$ Tris-HCl ( $\mathrm{pH} 7.9), 175 \mathrm{mM} \mathrm{NaCl}, 20 \mathrm{mM} \mathrm{EDTA}, 0.5 \mathrm{mg} / \mathrm{ml}$ ovalbumin, and $235 \mu \mathrm{M}$ $\$ 2238$ in a flnal volume of $1 \mathrm{ml}$. The conversion of $\mathrm{s} 2238$ was followed by measuring the absorbance change on an Aminco DW-2C spectrophotometer set in the dual wavelength mode at $405-500 \mathrm{~nm}$. The amount of prothrombin that $1 \mathrm{~s}$ activated in the reaction mixture was calculated from a callbration curve, made with known amounts of active site-titrated thrombin.

\section{RESULTS}

Cofactor dependence of venom prothrombin activators. Snake venom prothrombin activators may have different cofactor requirements to express 
maxlma1 prothrowbin-converting activity. To obtain information about the effect of cofactors on varlous wenom activators, prothrombin activation rates were determined as a function of the concentration of phospholipid (10\% PS, 90\% PC; mol/mol) in the absence as well as in the presence of bowlne factor Va (F1g. 1). In order to saturate all procoagulant sites that are avalable on the 11pid surface, the experiments have been carried out at high concentrations of coagulation factors and venom enzymes.

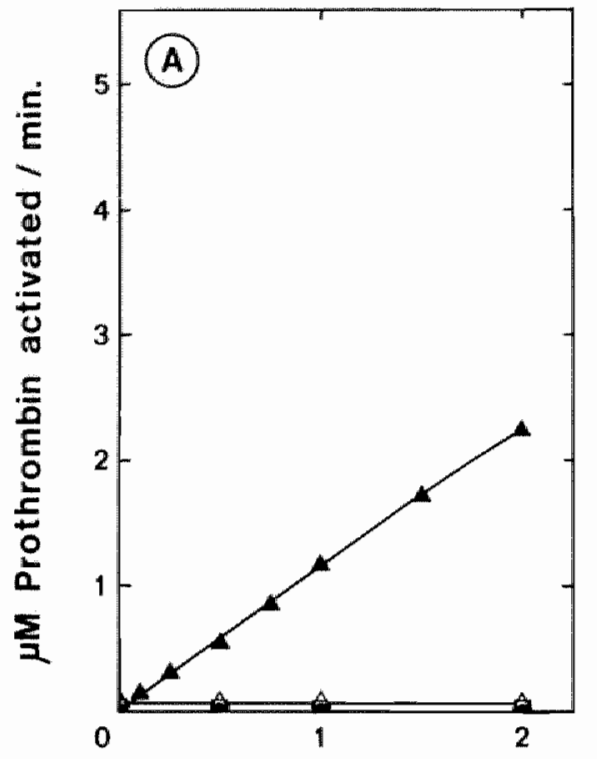

Phosphollipid $(\mu \mathrm{M})$

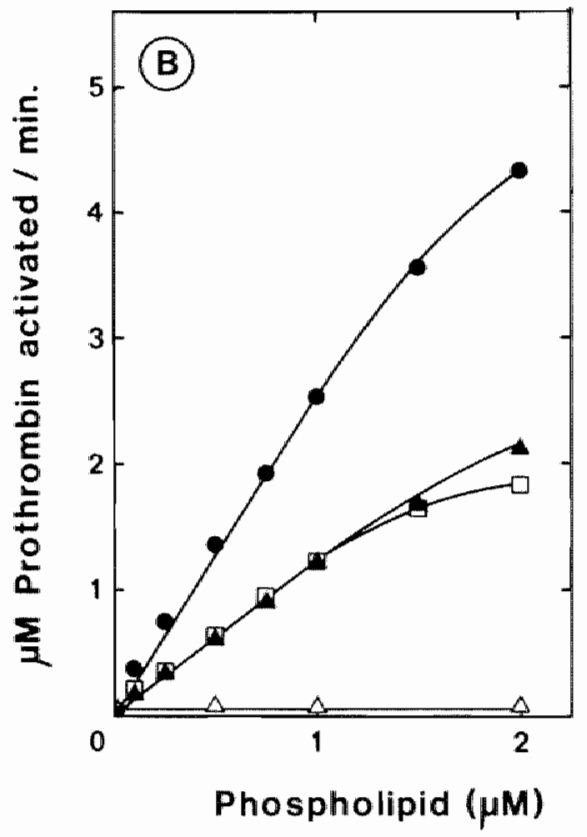

FIg. 1. Effect of phospholipld and Factor Va on rates of prothrombin activation by Factor $X a$ and venom prothrombin activators. Prothrombin activation was measured with varying anounts of phospholliplds (10\% PS, $90 \%$ PC) in the absence (A) or in the presence (B) of Factor Va. Actlvation rates were determined as described under "Materfals and Methods". The prothrombin activators tested were Factor $\mathrm{Xa}(-\bullet)$, and the venom activators from Notechls scutatus $(\square-\square)$, Dxyuranus scutellatus $(\Delta-\Delta)$ and Echis carlnatus $(\Delta-\Delta)$. Concentrations of protein, present in the final reaction system, were 2 wM prothromb1n, $5 \mathrm{nM}$ Factor $\mathrm{Va}$ (1f present), and $5 \mathrm{nM}$ prothrombin activator, with the exception of the venom activator from Eichis carinatus, which was present at 0.625 $\mathrm{mU} / \mathrm{m} 1$. The rates of prathrombin activation by factor $\mathrm{Xa}$ and Notechis scutatus in the presence of Factor Va and Oxyuranus scutellatus were corrected for the rates in free solution (12, 420 and $69 \mathrm{nM}$ prothrombin activated/min, respectively). 
The results show that Factor $\mathrm{Xa}$ and the actlvator from Notechls scutatus gave very 10w prothrombin activation rates in the absence of Factor Va, even when considerable amounts of phosphollpld were present (F1g. 1A). Both activators were stimulated enormously by Factor Va (FIg. 1B), and, under the experimental conditions, prothrombin activation was proportional to the phospholipld concentration, and thus proportional to the number of procoagulant sites present. Prothrombin activation by the oxyuranus scutellatus activator did not require Factor Va. In the absence of Factor Va (FIg. 1A), high rates of prothrombin activation were observed, that were proportlonal to the amount of phospholiptid present. Addition of Factor Va (F1g. 1B) had no further effect on the activation rates. Prothrombin activation by the purified prothrombin activator from the venom of Echis carlnatus was nelther affected by phospholiptds nor by Factor Wa.

From these experiments it is clear that we have the disposal of three different kinds of snake venom prothrombin activators. A Factor Xa-1ike activator, which is stimulated both by Factor Va and negatively charged phospholiplds (Notechis scutatus), an activator that acts 11ke the Factor Xa-Va complex, and which is only stimulated by phospholiplds (Oxyuranus scutellatus), and an activator that does not require cofactor components (Echis carinatus). The results also show that the activators ftom oxyuranus scutellatus and Notechis scutatus (In the presence of Factor Va) may be useful enzymes to probe phospholipid-11ke procoagulant activity.

Effect of platelets on prothrombin activation by various snake venom actlvators. The three snake venom prothrombin activators described above were used to probe the exposure of platelet procoagulant activity, Induced by various platelet stimulators. In order to discriminate between Factor Va and surface-effects on prothrombin activation, the rate of prothrombin activation in the presence of $1 \times 10^{7}$ platelets/m1 was measured in the presence as well as in the absence of added Factor Va. The results are summarized in Table I. Prothrombin activation by Echis carlnatus, whose venom activator requires no phospholipld or Factor Va, was not influenced by platelets, elther in the presence or in the absence of Factor Val "The same prothromblin activation rates were also observed in the presence of platelets stimulated with various platelet activators. 


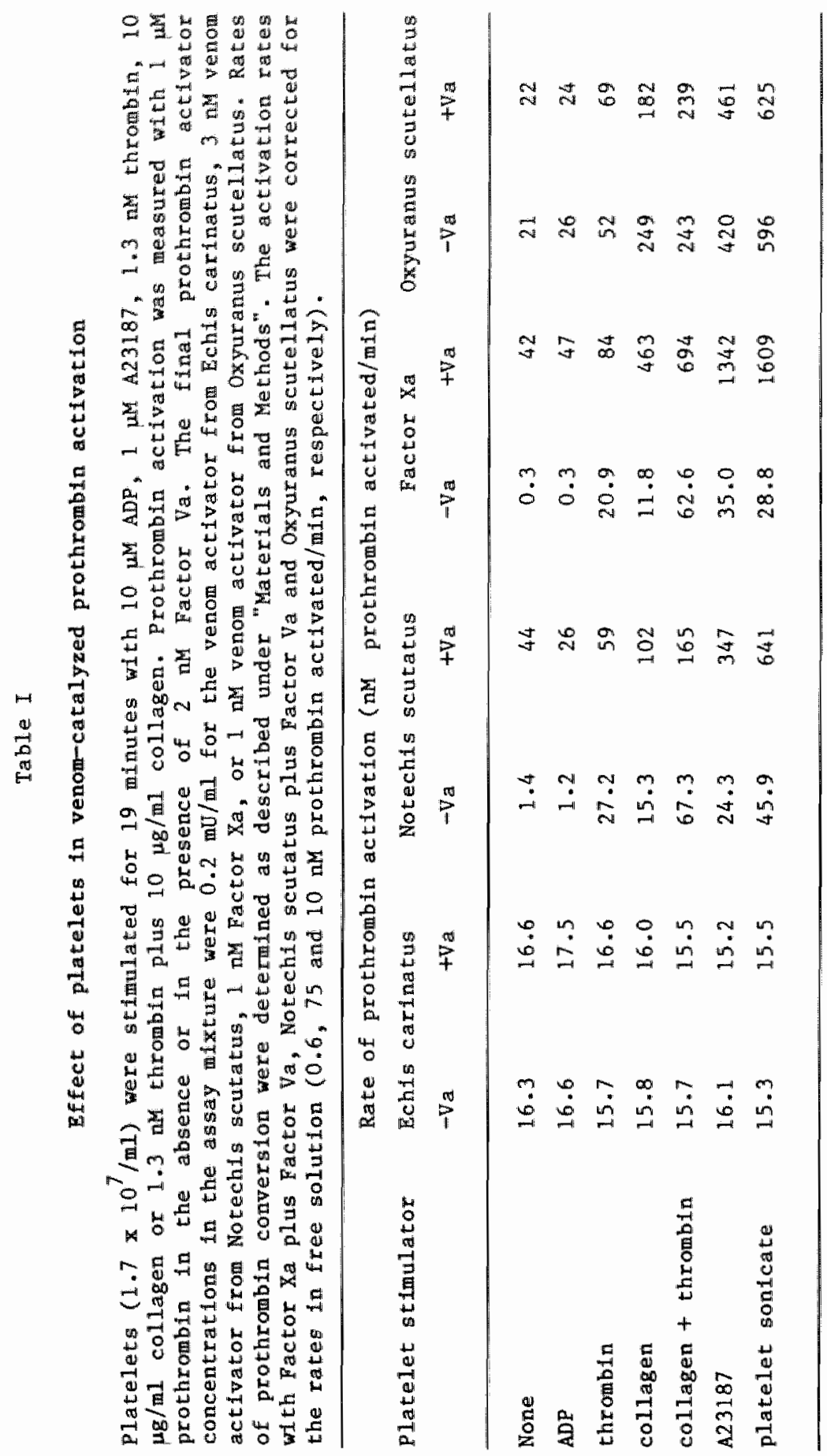


The phosphollpid- and Factor Va-dependent activator from Notechis scutatus shows a temarkable increase of prothrombln-converting actulty in the presence of stimulated platelets. The effect of platelets on prothrombin activation by this venom enzyme strongly resembles the plitelet effects on Factor Xarcatalyzed prothrombin conversion. The presence of added Factor Va greatly enhanced the prothrombin activation rate, both on stimulated and unstimulated platelets. With added Factor Va, ADP and thrombin seemed to be poor stimulators of platelet procoagulant activity, whereas collagen, or the combination of collagen plus thrombin, induced considerable prothrombin activation rates. The non-phystological calctum lonophore A23187 or a platelet sonicate gave the highest procoagulant activity. In the absence of added Factor Va, these effects were also vistble, although much lower rates of prothrombin conversion were found. Here, thrombin alone appeared to be a potent stimulator of platelet procoagulant activity. This effect is presumably due to the partictpation of platelet factor $V$ that $1 \mathrm{~s}$ released and activated by thrombin, rather than that $1 t$ is the consequence of any gross rearrangement af the phospholipid distribution of the platelet membranes.

The venom activator from oxyuranus scutellatus, whose prothrombinconverting activity in model systems is enhanced by phospholiplds, but not by Factor Va, is also stimulated by blood platelets. Resting platelets have a relatively low activity in prothrombin activation by the venom from Oxyuranus scutellatus. Activation of the platelets results in rate entancements that are comparable to the platelet-1nduced rate enhancements of the Factor Xa-Va-catalyzed prothrombin conversion. These results Indicate that platelets stimulate the activator of oxyuranus scutellatur and the Factor Xa-Va complex in simflar way. Whereas factor Xa needis Factor Va to bind to platelets and to promote its prothrombin converting activity (3), the oxyuranus scutellatus activator seems to blnd to platelets independent of Factor $V a$, since prothrombin activation rates in the presence of stimulated and unstimulated platelets are not affected by the presence of Factor Va. This phenomenon makes the oxyuranus scutellatus activator an interesting tool to further investigate the nature of the platelet procoagulant sites. The prothrombin activators from Notechis scutatus and Echis carinatus were not involved in further experinents. The activator from Notechis scutatus bears so much resemblance th Factor $X a$, 
that it 19 unlikely that if wil provide additlonal information about the nature of the procoagulant actuvity of platelets. The prothrombin activator from Echls carlnatus 18 not affected by platelets and is therefore not sultable to study the procoagulant properties of platelets.

Time course of generation of platelet prothrombin-converting activity probed wth Factor Xa-Va and 1 th the venom activator from oxyuranus scutellatus: The platelet prothrombin-converting activities, determined w1th varlous prothrombla activators reported in Table $I$, were probed after one single platelet activation time (1.e. 19 min.). In a separate expertment we have followed the time course of appearance of platelet procoagulant activity (data not shown). Platelets were stimulated with collagen plus thrombin, and their procoagulant activity was determined after different time Intervals by measuring the effect of activated platelets on prothrombln activation by the Factor Xa-Va complex or by the venom activator from oxyuranus scutellatus. The methodological approach used was Identical to that described in Table $I$.

The procaagulant activity of unstimulated platelets, as probed by both prothrombin activators, was low and did not change in time. Stimulation of the platelets by the combined action of collagen and thrombin resulted in a rapld rise of procoagulant activity. After a few minutes of stimulation, appreclable amounts of prothrombin were converted, both by the Factor Xa-Va complex and the oxyuranus scutellatus activator. Maximal rates of prothrombin actuation were obtained wh platelets that were stimulated for 20 minutes or more. For both activators, platelets reached half-maximal prothrombin-converting activity after 8-1.0 minutes of platelet stimulation, which suggeats that the Factor Xa-Va complex and the Oxyuranus scutellatus activator recognize the same platelet procoagulant sites.

Effect of phosphollpase A2 on the activity of stimulated platelets in prothrombin activation by Factor Xa-Va or oxyuranus scutellatus. In a previous paper (11), we have shown that incubation of stimulated platelets with Naja Naja phosphollpase $A_{2}$, an enzyme that can degrade phosphollp1d molecules exposed in the outer leaflet of cellular membranes without causing cell lysis, resulted in a dramatic decrease of platelet activity in Factor Xa-Va-catalyzed prothrombin conversion. It was also shown that this 
was not due to some adverse effect of phosphollpase $\mathrm{A}_{2}$ on coagulation factors or other platelet functions, and it was argued that the result was evidence for a phospholipid-1ike nature of the procoagulant stites of platelets stimulated with collagen plus thrombin.

We performed a simflar experiment with the prothrombin activator from oxyuranus scutellatus. Platelets were stimulated for 30 minutes with thrombin plus collagen and were subsequently treated wh th a small amount of phospholipase $A_{2}$. After different time intervals of phosphollpase treatment, the remaining platelet procoagulant activity was probed by addition of prothrombin and the Factor Xa-Va complex or oxyuranus scutellatus. In Fig. 2 it $1 \mathrm{~s}$ shown that phosphollpase $A_{2}$ quilckly reduced

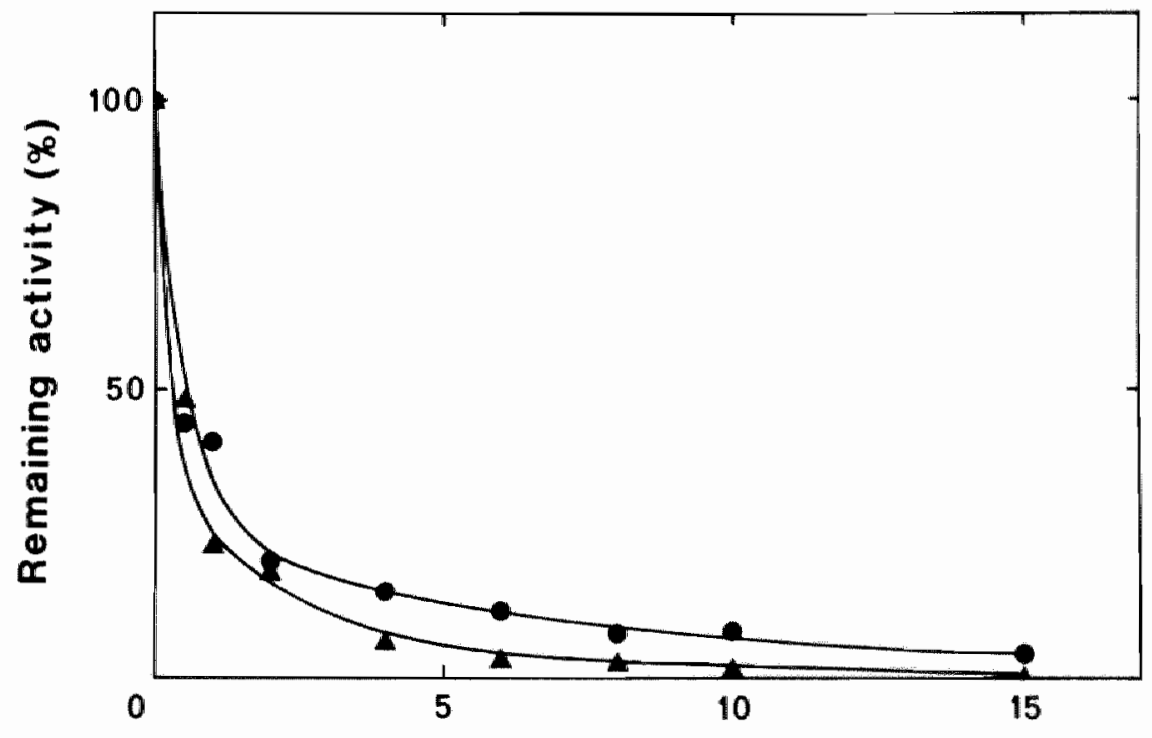

\section{Phospholipase incubation time (min.)}

F1g. 2. Effect of phospholipase $A_{2}$ on the activity of stimulated plateletg in prothrombin activation. Platelets $\left(4.3 \times 10^{6} / \mathrm{m} 1\right)$ were stimulated for 30 minutes with $1.3 \mathrm{nM}$ thrombin plus $10 \mu \mathrm{g} / \mathrm{ml}$ collagen. Subsequently, phosphollpase $A_{2}$ was added to the activation mixture at a final concentration of $0.02 \mathrm{IU} / \mathrm{ml}$. After the time intervals indicated, the remaining platelet activity in prothrombin conversion was measured as described under "Materials and Methods" * Prothrombin activation was determined at $0.5 \mu \mathrm{M}$ prothrombin and 0.5 nM Factor Xa plus 1 mM Factor Va $(-0)$, or at $0.5 \mu M$ prothrombin and $0.5 \mathrm{nM}$ oxyuranus scutellatus activator $(\boldsymbol{\Delta}-\boldsymbol{\Delta})$. Prothrombln act vation rates obtalned with 30-minute stimulated platelets, set at $100 \%$, remalned virtually constant when no phospholipase was added. 
the procoagulant activity of thromin plus collagen stimulated platelets, a teacured both 1 th the Factor Xa-Va complex and wh oxyranus scutellatus. This indicates that also in oxyuranus scutellatus-catalyzed prothrombin activation phospholiplds are an important component of the platelet procoagulant sites.

Determination of the number of procoagulant sites on platelet membranes. In an effort to quantitate the number of procoagulant sites on the platelet plasme membrane, experiments were set up to determine two parameters that are essential for sites calculation. The flrst parameter is the maximal prothrombin activation rate per platelet (Vsat). Th1s maximal rate is obtalned when all avallable procoagulant sites are saturated with the coagulation factors. The second parameter is the maximal rate of prothrombln activation (Vmax) that can be obtalned per enzyme complex, bound to the platelet surface. Division of these parameters ylelds the moles of bound enzyme complexes per platelet from which the number of procoagulant blinding altes can be calculated (see legend to Table II). For the determination of Vsat two titrations have to be performed. First, a titration with enzyme at a fixed platelet and prothrombin concentration, in order to determine the enzyme concentration required for saturation of procoagulant sttes, ts carried out. Subsequently, prothrombin concentrations were varied at the same platelet concentration and at a saturating enzyme concentration, in order to obtaln the maximal rate of prothrombin activation per platelet. For the determination of the maximal rate of prothrombtn activation per platelet-bound enzyme complex (Vmax) also two titrations were necessary. A titration with platelets (procoagulant sttes) at fixed enzyme and prothrombin concentrations was required to determine the platelet concentration at which all enzyme complexes bind to the platelet urface. Then, the concentration of prothrombin 1 s varled under conditions, at which all enzyme is bound to the platelet surface. This titration gives the Vmax of prothromblin activation per platelet-bound enzyme complex.

In principle this method can be applied to determine the sites on nonatimulated platelets as well as on platelets stimulated with various kinds of activators. In Fig. 3 we show a determination of sites on platelets that were stimulated wh collagen plus thrombin. The procoagulant sites generated were probed with Factor Xa-Va and with the prothrombin activator 

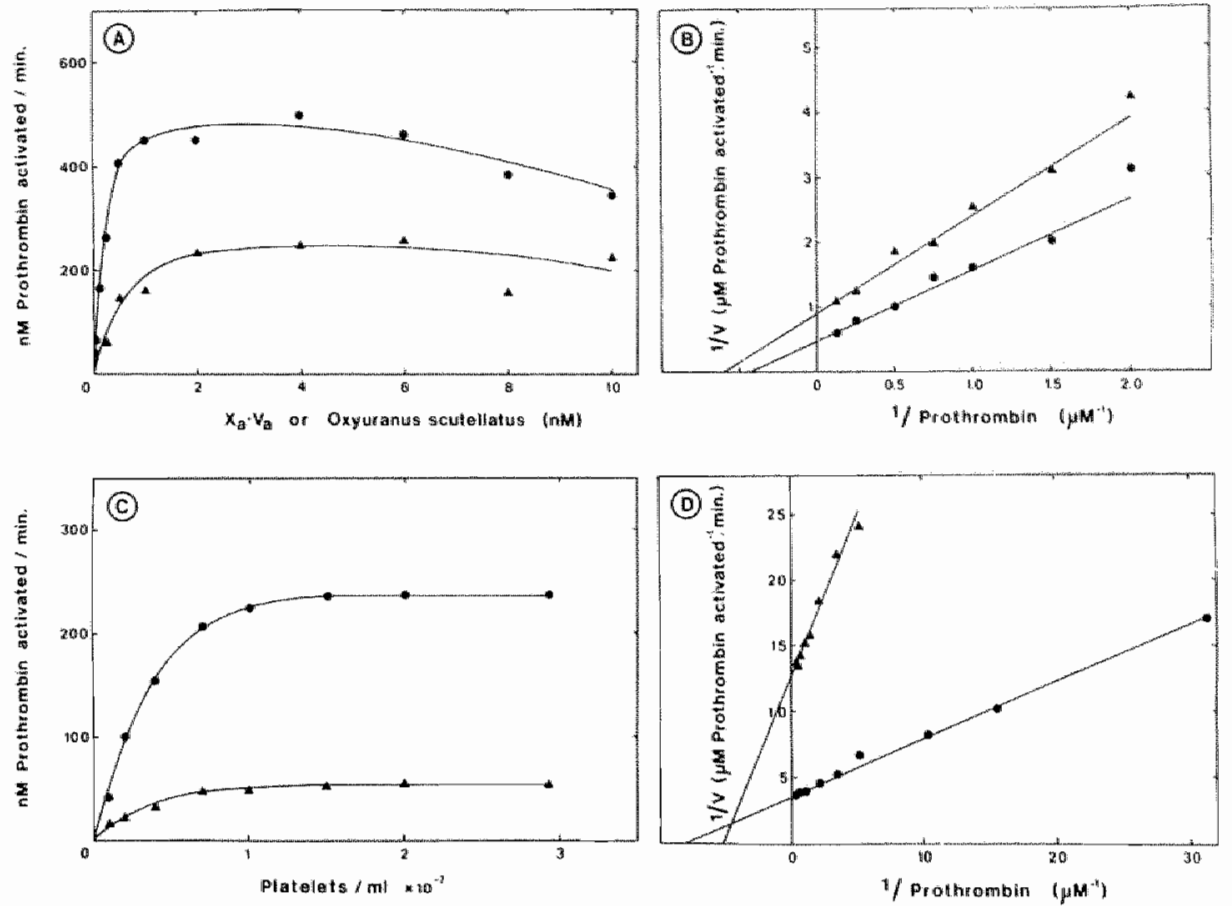

Fig. 3. Determination of the number of procoagulant sites for the Factor Xa$\mathrm{Va}$ complex and the oxyuranus scutellatus activator on platelet membranes. Platelets were stimulated for 19 minutes with $1.3 \mathrm{nM}$ thrombin and $10 \mathrm{\mu g} / \mathrm{ml}$ collagen. Then, coagulation factors were added and rates of prothrombin activation by Factor Xa plus Factor $\mathrm{Va}(-)$ ) or the venom activator from Oxyuranus scutellatus $(\boldsymbol{\Lambda}-\boldsymbol{\Delta})$ were measured as described under "Matertals and Methods". A) Determination of saturating enzyne concentrations. The concentrations of the Factor Xa-Va complex or the activator from Oxyuranus scutellatus were varled as indicated in the figure. Prothrombin activation was measured at $0.5 \mu \mathrm{M}$ prothrombin and $1 \times 10^{7}$ platelets/ml in the final reaction system. B) Determination of the maxtmit prothrombin activation rate with $1 \times 10^{2}$ platelets/m1. Rates of prothrombin activation with 5 nM Factor Xa plus 5 nM Factor Va or with $5 \mathrm{nM}$ oxyuranus scutellatus activator were measured at varylng prothrombin concentrations. The results are given in double recipracal plot. Kinet1c analysis gccording to Elsenthal and Cornish-Bowden (36) gives Vsat values of $2.09 \times 10^{-16}$ and $1.10 \times 10^{-16}$ moles of prothrombin activated/min/platelet for the Factor Xa-Va complex and oxyuranus scutellatus activator, respectively. C) Effect of the platelet concentration on prothrombin activation by a 11mited amount of enzyme. Prothrombin activation was measured with $0.5 \mu \mathrm{M}$ prothrombin, $0.1 \mathrm{nM}$ Factor Xa and $0.5 \mathrm{nM}$ Factor Va, or with $0.5 \mu \mathrm{M}$ prothrombin and $0.089 \mathrm{nM}$ Oxyuranus scutellatus activator. D) Determination of the maximal prothrombin activation rate per plateletbound enzyme complex. Rates of prothromb1n activation in the presence of $2 \times 10^{7}$ platelets/m1 were measured at varylng prothrombln concentrations. The Factor Xa and Factor Va as well as the Oxyuranus scutellatus concentrations were the same as under (C). Kinetic analysis gives Vmax values of 2822 and $906 \mathrm{nM}$ prothrombin activated/min/nM enzyme for the Factor Xa-Va complex and the oxyuranus scutellatus activator, respectively. 
from the venom of oxyuranus scutellatus. To determine saturating enzyme concentrations, platelets $\left(1.7 \times 10^{7} / \mathrm{m} 1\right)$ were atimulated for 19 minutes with collagen plus thrombln and varyling amounts of Factor Xa-Va or oxyuranus scutellatus activator were bubsequently added. Finally, prothrombln $(0.5$ HM) added to start the reaction. Fig. 3A shows that at concentrations of enzyme > 2 nM saturation of procoagulant stes is achieved. The maximal rate of prothrombin activation with stimulated platelets $\left(1 \times 10^{7} / \mathrm{m} 1\right)$ at saturating enzyme concentrations $(5 \mathrm{nM})$ was then found by varying the prothrombin concentration. Vsat values were obtained from double reclprocal plots of the rate of prothrombin activation versus the prothrombin concentration (F"1g. 3B).

The effect of the concentration of stimulated platelets on prothrombin activation by a $11 m i t e d$ amount of Factor Xa-Va complex ( $0.1 \mathrm{nM})$ or Oxyuranus scutellatus actlvator $(0.089 \mathrm{nM}) \mathrm{is}$ shown $\mathrm{in}$ Fig. 3C. It appeared that platelets at concentrations above $1.5 \times 10^{7} / \mathrm{m} 1$ did not further increase the reaction rate. Apparently, at $1.5 \times 10^{7}$ platelets/m1, a11 enzyme 1 s bound to the platelet surface and is Involved 1 in prothrombin activation. The maximal rate of prothrombin conversion for $0.1 \mathrm{nM}$ platelet-bound enzyme was subsequently obtalned by varyling the prothrombin concentration. The result of this experiment, which is given as a double reclprocal plot, is shown in F1g. 3D. From the maximal rates of prothrombin activation determined in F1gs. $3 B$ and 3D, it can be calculated that collagen plus thrombin-stimulated platelets expose 44600 sites/platelet for Factor Xa-Va-catalyzed prothrombin activation and $73100 \mathrm{sites} / \mathrm{platelet}$ for the oxyuranus scute1latu dependent reaction (Table II).

A similar set of titratlons was carried out to determine the number of procoagulant sltes for the Factor Xa-Va complex and Oxyuranus scutellatus on non-stimulated platelets (data not shown). Non-stimulated platelets expose conslderably less procoagulant sites than platelets activated with collagen plus thrombin. For Factor Xa-Wa there are 2020 sites/platelet and for the prothrombin activator from Oxyuranus scutellatus there are 3640 sites/platelet (Table II).

In the sites calculation presented above 1 is assumed that in the determination of the Vmax (F1g. 3D) all added enzyme molecules participate in prothrombin activation. It cannot be excluded, however, that at the limiting amounts of prothrombin activator employed in these experiments, a 
Table II

Procoagulant sites on human platelets

The number of functional procoagulant sltes was calculated from the formula: number of sites per platelet = Vsat/Vmax $x$ Avogadro's number. Wsat is the rate of prothrombin activation determined with saturating concentrations of activator and prothrombin at non-stimulated platelets (data not shown) or at platelets stimulated with thrombin plus collagen (Fig. 3B). Vmax is the maximal rate of prothrombin activation per molecule of surface-bound activator determined on platelets (Fig. 3D) or obtalned from literature $(17,33)$.

\begin{tabular}{|c|c|c|c|c|}
\hline \multirow[b]{2}{*}{ Platelet stimulator } & \multicolumn{2}{|c|}{ sites/platelet } & \multicolumn{2}{|c|}{ sites/platelet ${ }^{2}$} \\
\hline & $\begin{array}{l}\text { Factor } \\
\text { Xa-Va }\end{array}$ & $\begin{array}{l}\text { Oxyuranus } \\
\text { scutellatus }\end{array}$ & $\begin{array}{l}\text { Factor } \\
\text { Xa-Va }\end{array}$ & $\begin{array}{l}\text { oxyuranus } \\
\text { scutellatus }\end{array}$ \\
\hline None & 2020 & 3640 & 1425 & 1940 \\
\hline Thrombin + collagen & 44600 & 73100 & 31.460 & 38970 \\
\hline
\end{tabular}

${ }^{1}$ Calculated with Vmax values determined in Fig. 3D for the Factor Xa-Va complex $\left(2822 \mathrm{mln}^{-1} 2_{1}\right.$ ar the venom prothrombin activator from oxyuranus scutellatus ( $906 \mathrm{~min}^{-1}$ ).

${ }^{2}$ Calculated with Vmax values determined op artiflcial phospholipid vesicles for the Factor $X a-V a$ complex $\left(4000 \mathrm{~min}^{-1}\right.$, cf. ref. 33) of for the venom prothrombin activator from oxyuranus scutellatus (1700 min ${ }^{-1}$, cf. ref. 17).

fraction of the activator molecules may bind to the platelets in a non-spectfic and non-productive manner (cf. ref $3,8,32$ ). Thts would result In an underestimation of the Vmax of prothrombin activation. Indeed in model systems in which artificlal phospholipld vestcles were used as procoagulant surface, higher Vmax values were observed for the Factor Xa-Va complex (33) as well as for the prothrombin activator from the venom Oxyuranus scutellatus (17). Using the Vmax values reported in 11terature, a somewhat lower number of sites per platelet was obtained for both the Factor Xa-Va complex and the venom activator from oxyuranus scutellatus, and there was a closer agreement between the number of sites calculated for both prothrombin activators (Table II). 


\section{DISCUSSION}

In this paper present experiments in which a numer of snake venom prothrombin actluators were used as probes for platelet procoagulant activity. The activity of platelets in prothrombin activation is thought to proceed wa blnding, Interaction and reaction of the coagulation factors at spectfic stees on the platelet membrane surface. These sites may be composed of elther speciflc protein receptors or negatively charged phosphollpid, the latter being less speciflc in that they wil interact wth other coagulation factors, such as those of the Factor X-activating complex.

The phosphollpid binding site model $1 \mathrm{~s}$ supported by the observation that phosphatidylserine residues become exposed on the outer leaflet of the platelet plasma membrane upon platelet activation (10). Since the exposure of phosphatidylserines colncides 1 th an increase of platelet prothrombinand Factor $X$-converting activity $(6,34)$, and since the platelets of a patient with a mild bleeding disorder (Scott syndrome) were impaired as wel1 In their ablity to expose phosphatidylserine and to generate prothrombin- and Factor X-converting activity (35), it was proposed that phosphatidylserine plays an important role in the binding of the proteins of the prothrombin- and Factor X-activating complexes to the platelet membranes.

In this mode1 also an interaction of platelets with phospholipiddependent snake venom prothrombin activators can be expected. In this respect the prothrombin activator of oxyuranus scutellatus may be a potent tool In Investlgating the nature of the procoagulant sites on the platelet. membrane. This venom activator is phospholipld dependent, but does not need Factor Va for procoagulant activity (17). Upon platelet activation, it can therefore probe changes in the platelet membrane phospholipids without measuring any, often confusing, effect of Factor $V$ release and activation.

A number of observations show that oxyuranus scutellatus probes for the same procoagulant sites on the platelet plasma membrane as the Factor Xa-Va complex. Prothrombin activation by the Factor Xa-Va complex and the Oxyuranus scutellatus activator is simflar with respect to the effect of platelets stimulated with varlous triggers. ADP and thrombin hardly affect platelet procoagulant activity, as probed with both prothrombin activators, 
Whereas collagen or the combination of collagen plus thrombin are the most potent physiological platelet stimulators. It is shown that the time course of generation of the platelet procoagulant surface, induced by the action of collagen plus thrombin, is the same, irrespective of whether it is determined with Oxyuranus scutellatus or with the Factor Xa-Va complex. Furthermore, the number of procoagulant sites for both activators is approximately the same, both with collagen plus thrombin stimulated and with unstimulated platelets (Table II). Treatment of activated platelets Wth small amounts of phospholipase $A_{2}$ leads to a rapld loss of platelet activity in Factor Xa-Va- and Oxyuranus scutellatus-catalyzed prothrombin converston.

These results are consistent with phospholipld involvement in the binding of both activators. The explanation of the results presented in this paper does not require postulation of protein receptors that are involved in the binding of the proteins of the prothrombinase conplex to the platelet membrane. We feel that our data even argue agalnst the involvement of receptor proteins since it is unlikely that such a receptor, speclftcally designed for the Factor Xa-Va complex, would also efficlently blnd a snake venom protein. Although the oxyuranus scutellatus activator contalns a cofactor which functions like factor Va (17), it has several properties uncommon with Factor Va. In contrast to Factor Va, the oxyuranus scutellatus cofactor is not inactivated by EDTA or activated protein $C$ (16). The isolated cofactor part from the venom activator from oxyuranus scutellatus also lacks the ability to promote prothrombln activation by bovine Factor Xa (17). In summary we conclude that Oxyuranus scutellatus and the Factor Xa-Va complex recognize the same procoagulant sltes on both stimulated and non-stimulated platelets and that negatively charged phospholiplds are an essentlal component of these procoagulant sites.

Acknowledgements. This work was supported by Program Grant 900-526-093 from Medigon (The Dutch Foundation for Medical- and Health Research). We thank $A B$ Kabl Dlagnostica for kindly providing part of the chromogentc substrates used in this study "Marlet Molenaar-van de Voort is acknowledged for typing this manuscript and we thank Willy Linskens, Paul Comfurlus and Peter Verhallen for the preparation of the platelets used in this study. 
1. Walsh, P.W. and Blggs, R. (1972) Brit. J. Haematol. 22, 743-760.

2. Wa1sh, P.N. (1978) Br1t. J. Haematol. 40, 311-331.

3. MLletich, J.P., Jackson, C.M. and Majerus, P.W. (1978) J. Biol. Chem. $253,6908-6916$.

4. Dahlback, B. and Stenflo J. (1978) Blochemistry 17, 4938-4945.

5. Tracy, P.B., Eide, L.L. and Mann, K.G.(1985) J.Bio1.Chem. 260, 2119-2124.

6. Rosing, J*, van Rijn, J.L.M.L., Bevers, E.M., van Dieljen, G., Comfurlus, P. and Zwal, R.F.A. (1985) Blood 65, 319-332.

7. M1letLch, J.P., Kane, W.H., Hofman, S.L., Stanford, N. and Majerus, P.W. (1979) B1ood 54, 1015-1022.

8. Kane, W.H. and Majerus, P.W. (1982) J. Blo1. Chem. 257, 3963-3969.

9. Mann, K.G., Neshe1m, M... and Tracy, P.B. (1986) in New Comprehensive Blochemistry Vol. 13, Blood Coagulation (Zwaal, R.F.A. and Hemker, H.C., eds.) 15-34, Elsevler Amsterdam, The Netherlands.

10. Bevers, E.M., Comfurius, P., van Rijn, J.L.M.L., Hemker, H.C. and Zwaal, R.F.A. (1982) Eur. J. Blochem. 122, 429-436.

1.1. Bevers, E.M., Comfurlus, P. and Zwaa1, R.F.A.(1982) Eur.J.Biochem.122,81-85.

12. Zwal, R. F.A. (1978) Bloch1m. Blophys. Acta 515, 163-205.

13. Rosing, J., Zwaal R.F.A. and Tans, G. (1987) in Anlmal Venoms and Hemoatasla (Pirkle, H. and Markland, jr. F.S. eds.) Marcel Dekker, Inc., New York, U.S. In press.

14. Mortta, T. and Iwanaga, S. (1978) J. Blochera. 83, 559-570.

15. Gufllin,M.C., Bezeaud,A., Menache, D.(1978) Blochim.Blophys.Acta 537, 160.

16. Walker,F.J., Owen,W.G. and Esmon, C.T. (1980) B1ochemistry 19, 1020-1023.

17. Spe1Jer, H., Govers-R1emslag, J.W.P., Zwaal, R.F.A. and Ros1ng, J. (1986) J. B101. Chem. 261, 13258-13267.

18. Jobln, F. and Esnouf, M.P. (1966) Nature 211, 873-875.

19. Tans, G., Govers-R1emslag, J.W.P., van Rijn, J.L.M.L. and Rosing, J. (1985) J. Biol. Chem. 260, 9366-9372.

20. Zwaal, R.F.A., Roelofsen, B. Comfurius, P. and van Deenen, L. L.M. (1975) Blochim. Blophys. Acta 406, 83-96.

21. Owen,W.G., Esmon, C.T. and Jackson, C.M.(1974) J.Bio1.Chem. 249, 594-605.

22. Fufikawa,K., Legaz,M.E. and Davie, E.W.(1972) Blochemistry 11, 4882-4891.

23. Rosting, J., Tans, G., Govers-Rlemslag, J.W.P., Zwaal, R.F.A. and Hemker, H.C. (1980) J. B1o1. Chem. 255, 274-283.

24. LIndhout, M.J., Govers-Rlemslag, J.W.P., van de Waart, P., Hemker, H.C. and Rosing, J. (1982) Blochemistry 21, 5494-5502.

25. Chase, T. Jr. and Shaw, E. (1969) Biochemistry 8, 2212-2224.

26. Sanith, R. L. (1973) J. Biol. Chem. 248, 2418-2423.

27. Lowry, O.H., Rosebrough, N.J., Farr, A*L. and Randal1, R.J. (1951) J. Blo1. Chem. 193, 265-275.

28. Kettner, C.A. and Shaw, E.N. (1981) Methods Enzymo1. 80, 826-842.

29. Sedmak, J.J. and Grossberg, S.E. (1977) Anal. Blochem. 79, 544-552.

30. Comfurlus, P. and Zwal. R.F.A. (1977) Blochim. Biophys. Acta 488, 36-42.

31. Bóttcher, G.J.F., van Gent, C.M. Pries,C.(1961) Anal.ChIm.Acta 24, 203-207.

32. Tracy, P.B., Nesheim,M.E. and Mann,K.G.(1981) J.B101.Chem. 256, 743-751.

33. van RIJn, J.L.M.L., Govers-Riemslag, J.W.P., Zwaal, R.F.A. and Roging, J. (1984) Blachemfstry 23, 4557-4564.

34. Bevers, E.M., Comfurius, P. and Zwaal, R.F.A. (1983) Biochim. Blophys. Acta $736,57-66$.

35. Rosing, J., Bevers, E.M., Comfurius, P., Hemker, H.C., van Dieljen, G., Welss, H.J. and Zwaal, R.F.A. (1985) Blood 65, 1557-1560.

36. Elsentha1, R* and Cornish-Bowden, A. (1974) Biochem. J. 139, 715-720. 
CHAPTER V

THE EFFECT OF SURFACE CHARGE OF PHOSPHOLIPID VESICLES ON THEIR ACTIVITY IN PROTHROMBIN ACTIVATION

\section{SUMMARY}

The conversion of prothrombin into thrombla, which is a cruclal reaction In haemostatic plug formation, is greatly stimulated by phospholipids plus calcium ions. It has been proposed that phosphollpid surfaces which promote blood coagulation should have a negative surface charge (Bangham, A.D. (1961) Nature 192, 1197-1298). However, the expertments that led to this proposal were carried out with one kind of antonic phospholipid (dicetyl phosphate). Here we report that membranes, which contaln phosphatidylserine (PS) as anionic phosphollpld, can be made positively eharged by 1ncorporation of stearylamine, and still exhlbit almost full procoagulant and prothrombin-converting activity. This suggests that electrostatic forces hardly contribute to the binding of coagulation factors to ps-containing membranes. Introduction of stearylamine in membranes containing phosphatidic actd, phosphatidylglycero1, phosphatidylinosttol or phosphatidyl- $\beta$-lactate (PLac) causes considerable inhibition of thelr prothrombin-converting activity. Comparison of vesicles containing PS and PLac as anionic phospholipid is of speclal interest. Since PLac and PS only differ by the presence of an amino group in the polar head group, the much higher procoagulant activity of PS-containing vesicles ls indicative for an important function of this amino group of PS in the interaction with coagulation factors. We propose that the assoclation of coagulation factors with PS-contalning metroranes results from complex formation between $\mathrm{Ca}^{2+}-10 \mathrm{~ns}$ and 1igands supplied by the proteln and by $\mathrm{PS}$ molecules. The possibility to form such a complex may explatn why cell membranes wth $\mathrm{PS}$ have such excellent procoagulant propertiea. 


\section{INTRODUCTION}

The activation of the vitam in $k$-dependent coagulation factor prothrombin 18 greatly accelerated by the non-enzymatic proteln cofactor va and by phospholiplds plus calclum lons. Kinetic studles have shown that the stimulatory effects by these so-called "accessory components" are due to favourable changes of the kinetlc parameters of prothrombin activation, $1 . e$. a decrease of the $\mathrm{Km}$ for prothrombin (1-4) and an increase of the Vmax of the reaction $(1,5)$. Although not much 1 s known about the molecular mechanism by which Factor $\mathrm{Va}$ enhances the catalytic activity of Factor Xa, there is ample Information about the function of phospholipids in the activation of prothrombin. Already in 1967, Jobin and Esnouf (6) and Hemker et al. (7) proposed that the phospholipld-induced acceleration of prothrombin activation was the result of the binding and proper assembly of the particlpating protelns (prothrombin, Factor Xa and fractor Va) at the phospholipld surface, which factlitate the interactions and hence the reactions between the protelns involved in prothrombin activation. More recent kinetic studies (1-5) support the notion that the enzymatic unit of the prothrombin activator consists of a four component complex (Factor $\mathrm{x}_{\mathrm{a}}$-Factor $\mathrm{V}_{\mathrm{a}}$-calciumphospholipid) that acts on prothrombin. To obtain optimal rates of activation, prothrombin also has to interact with phospholipids. Indeed, the ability to bind prothrombin, Factor Xa and Factor Va is a prerequisite for procoagulant membranes. In order to associate with the protelns of the prothrombinase complex the membrane should contaln negatively charged (anionic) phospholiplds. The presence of such phospholipids is essential for the binding of Factor Va (8-10) and for the formation of calclum bridges with the $\gamma$-carboxyglutam $\mathbb{1}$ acld residues of prothrombln and Factor Xa (11-13).

With respect to the relationship between the procoagulant activity and the chemical and physical propertes of the membranes, there are sit11 some unresolved questions. In 1961, Bangham (14) demonstrated with coagulation tests that procoagulant phospholipld bilayers have to possess a net negative charge. This observation was confirmed by Papahadjopoulos et a1. (15), who also showed that the procoagulant properties of a membrane mainly depend on the surface charge and not on the chemical structure of its antonic phospholipids. However, more recent reports by Pusey and Nelsestuen (2) and van $R I j n$ et al. (3) Indicate that there is no obvious relationship between 
the surface charge of procoagulant membranes, thelr affinfty for coagulation factors and thelr abllity to stimulate prothromblnase. Membranes, whlch contained phosphatidylserine as negatively charged phospholiptd, exhiblted maximal catalytic efflelency at rather low phosphatidylserine content $(2.5-$ 10 mol $\%$ ). It was also shown that membranes wh phosphatidylserine were more active than those containing phosphatidic acld although membranes with the latter phosphollpid have higher surface charge. At Increasing amounts of negatively charged phospholipid (20-40 mol \%) membranes with phosphatidylgiycerol, which actually have the lowest affinity for coagulation factors, showed the highest activity in prothrombin activation.

The experiments described in this paper were undertaken, in order to obtain more information on some unanswered questions regarding the effects of the surface charge and the chemical nature of anionic phospholiplds on the activity of procoagulant membranes in prothrombin activation.

\section{EXPERIMENTAL PROCEDURES}

Reagents. S2238 was purchased from AB Kab1 Diagnost1ca, p-NPGB was from Nutritional Blochemicals. Ovalbumin, Russell's viper venom, Echis carinatus venom and 1,2-dloleoyl-sn-glycero-3-phosphocholine were obtalned from Sigma. Phosphatidylinositol was obtalned from Koch Light. Column materials for protein purification (DEAE-Sephadex A-50, QAE-Sephadex A-50, SP-Sephadex $C-50$, Sephadex $G-100$ and $G-200$ and sepharose 4B) were purchased from Pharmacla. Stearylamine (octadecylamine) was from Sigma. Agarose (Irogel agarose-EF) used for the electrophorests of phosphollptd vestcles was obtalned from LRB.

Proteins. Bovine prothrowbin was purifted according to the method of owen et a1. (16). Thrombln was purifled as deacribed earlier (1). Bovlne Factor $x$ and Factor Xa were prepared according to the method of Fujlkawa et al. $(17,18)$. Bovine Factor Va was obtalned accordling to the procedure of Lindhout et al. (19). Proteins were stored at $-80^{\circ} \mathrm{C}$ in $50 \mathrm{mM} \operatorname{Tr} 1 \mathrm{~s}-\mathrm{HCl}, 175$ mM NaCl and $0.5 \mathrm{mg} / \mathrm{ml}$ ovalbumin. Factor Va was stored in the same buffer containing $5 \mathrm{mM} \mathrm{CaCl}_{2}$. 
Phospholiplds and phosphollpld veslcle preparations. 1,2-DLoleoy 1-sn-g1ycero-3-phosphoser1ne, 1,2-dioleoyl-sn-glycero-3-phosphoglycerol, 1,2-diol-

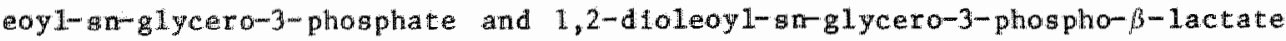
were prepared from 1,2-doleoy1-sn-glycero-3-phosphocholine by enzymatic synthest: as deacrlbed by Comfurtus and Zwal (20). Single-bilayer phospho11pld vesicleg were prepared by sonlcation according to the method of de Krulfff et al. (21). Phosphollpld concentrations were determined by phosphate analysis as described by Bottcher et al. (22). The concentration of stearylamine was determined by nitrogen analysis according to ward et al. (23), using an Antek digital nitrogen detector mode1 720 coupled to an Antek pyroreactor 771 .

Proteln concentrations. Active site titration with P-NPGB was used to determine the molar concentrations of thrombin (24) and Factor Xa (25). Prothrombin concentrations were determined by the same method (24) after complete activation of prothrombin with the venom activator from Echls carinatus. The concentration of Factor Va was determined by kinetic analysis as described by Lindhout et 1 . (19).

Assay system for measuring rates of prothrombin activation. Phosphollpids and Factor $\mathrm{Xa}$, either with or without Factor Va, were incubated for 5 min at $37{ }^{\circ} \mathrm{C}$ in a buffer containing $50 \mathrm{mM} \mathrm{Tr} 1 \mathrm{~s}, 175 \mathrm{mM} \mathrm{NaCl}, 5 \mathrm{mM} \mathrm{CaCl}$ and 0.5 $\mathrm{mg} / \mathrm{ml}$ ovalbumin at $\mathrm{pH} 7.9$. Prothrombin activation was started by the addition of prewarmed prothrombin in the same buffer. After different time Intervals, samples from the reaction mixture were transferred to cuvettes contalning $235 \mu \mathrm{M}$ of the thrombin-spectifc chromogenic substrate 52238 in 50

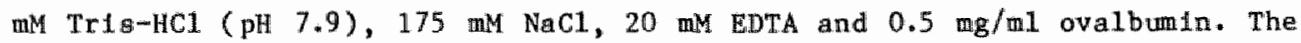
amount of prothrombin activated in the reaction aliquots was calculated from the absorbance change $(\Delta A 405-500 / \mathrm{m} 1 \mathrm{n})$, recorded on an Aminco $\mathrm{DW}-2 \mathrm{~A}$ spectrophotometer operating in the dual-wavelength mode, and a callbration curve of chromogenlc substrate conversion by known amounts of active sitetiterated thrombin.

Coagulations tests. Coagulation tests (Stypven time and Activated Partial Thromboplastin Time) were performed as described by Denson (26). 
Electrophoresis of phospholipid veslcles. The electrophoretic mobility of phospholipid vesicles was determined by electrophorests on flatbed agarose gels. The agarose gels were obtained by application of a warm $\left(60^{\circ} \mathrm{c}\right)$ solution of $0.3 \%$ agarose in $50 \mathrm{mM}$ Tris, $175 \mathrm{mM} \mathrm{NaCl}$ (pH 7.9) onto a glass plate. The phospholipid vesicles, usually 4 ul of a solution containing 2 mM phosphollptd were applied to the agarose gel in small cylindrical holes plerced in the middle part of the gel. Electrophoresis was carried out for $2 \mathrm{~h}$ at $15^{\circ} \mathrm{C}$ at $3.5 \mathrm{Volt} / \mathrm{cm}$ on a LKB 2117 Multiphor electrophores1s apparatus. The electrode buffer, which was the same in the cathode and anode compartments, contalned $50 \mathrm{mM}$ Trls, 175 m NaCl (pH 7.9). During the electrophoresis the electrode buffers were refreshed several times in order to keep their $\mathrm{pH}$ and fondc composition constant. After electrophoresis the phospholipld vesicles were stained by Incubating the agarose gel in a saturated solution of lodine in water/ethanol $(95 / 5 ; \mathrm{v} / \mathrm{v})$.

\section{RESULTS}

Prothrombin activation on membranes with low phosphatidylserine content. In an earlier publication (3), we have shown that the complete prothrom binase complex (Factor Xa, Factor $\mathrm{VA}, \mathrm{Ca}^{2+}$-lons and phosphollpid) has a rather low requirement for negatively charged phospholipids, since membranes with low mol percentages phosphatidylserine exhibited the highest catalytic efflctency. Phospholiptd vestcles with amounts of phosphatidylsertne as low as 2 mo1\% st111 malntalned favourable kinetic parameters for prothrombin activation. In these experiments, the prothromblnase complex had such a low phosphatidylserine requirement that it even becomes questionable whether prothrombin activation was actually still dependent on the presence of negatively charged phospholipids. However, In Fig. 1 it is shown that membranes have to contaln megatively charged phospholfplds in order to promote prothrombin activation. In this experiment, phospholipid vesteles with $0, \frac{1}{2}, 1,2,3,4$ or 5 mol \% phosphatidylserine were compared with respect to their ability to stimulate prothrombin activation. When Factor va 1s part of the prothrombin-activating complex, membranes containing 3-5 nol * phosphatidylserine showed optimal prothrombin-converting activity. At lower mol percentages of phosphatidylserine there was a gradual decrease of 


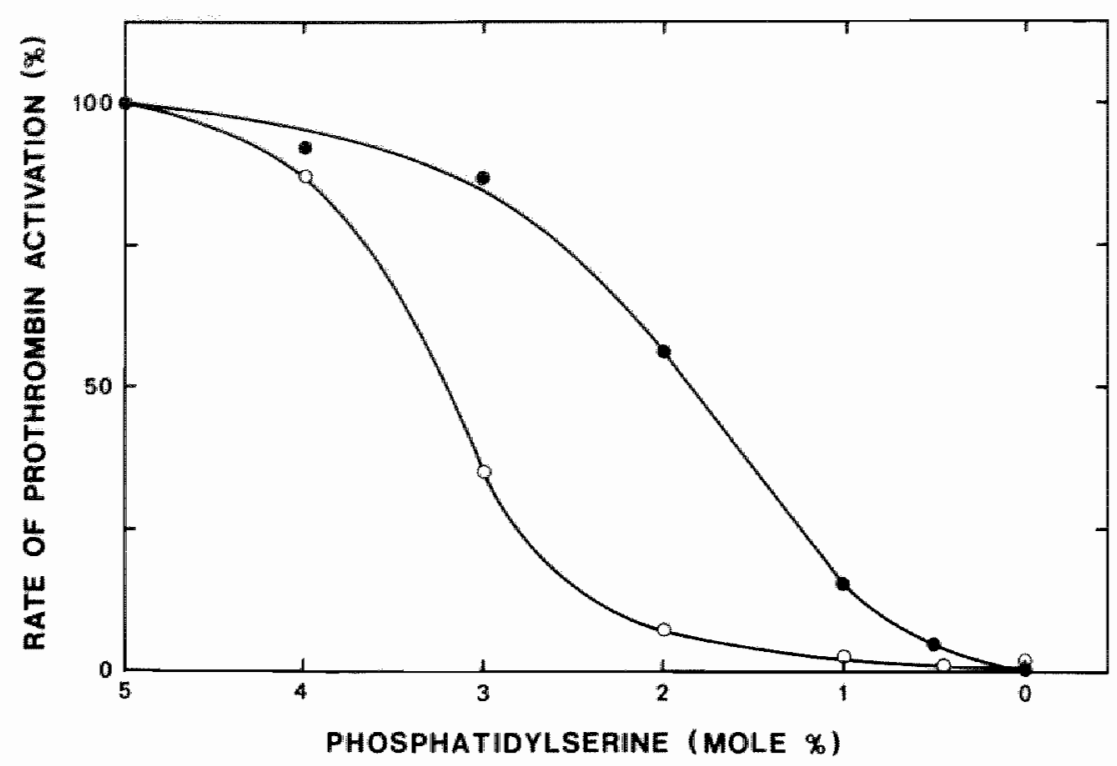

Fig. 1. Effect of the mol percentage phosphatidylserine on the activity of phospholipld vesicles in prothrombin activation. Prothrombin $(0.5$ UM) was activated in a reaction mixture containing $50 \mathrm{mM}$ Tris-HCl $(\mathrm{pH} .7 .9), 175 \mathrm{mM} \mathrm{NaCl}, 5 \mathrm{mM} \mathrm{CaCl}, 0.5 \mathrm{mg} / \mathrm{ml}$ ovalbumin, $50 \mu \mathrm{M}$ phospholip1d (PS/PC with amounts of PS Indicated in the figure), and 1 pM Factor Xa plus 5 nM Factor Va (0-0), or 2 nM Factor Xa $(0-0)$. Rates of prothrombin activation were determined as described in the experimental procedures. $100 \%$ corresponded with rates of 2160 moles prothrombin activated per min per mol Factor Xa (-) or 0.17 moles prothrombln activated per intn per mol Factor Xa $(\mathrm{O}-\mathrm{O})$.

the abtlity of membranes to promote prothrombin activation. Membranes Whout phosphatidylserine, which were only composed of the neutral phospholipid phosphatidylcholine, did not show detectable activity in prothrombin activation.

Stmilar observations were made for prothrombin activation by Factor Xa in the absence of Factor $V_{a}$. Under these conditions, vesicles with 5 mol $\%$ phosphatidylserine exhlbited already diminlshed prothrombin-converting activity 1 if compared with membranes containing higher mol percentages phosphatidylserine (data not shown). A further decrease of the phosphatidylserine content of the membranes resulted in a considerable decrease of their procoagulant activity. In the absence of Factor Va, membranes with mol 
percentages phosphatidylserine below $2 \%$ were not able to stinulate prothrombin activation.

From these experiments, we conclude that, although the prothrombinase complex functions very well on membranes wth low anounts of phosphat ldy 1serine, there 15 still an absolute requirement for the presence of negatively charged phosphollpids.

Prothrombin activation on phospholipid vestcles with positive electrostatic potential. In the experiment presented in the prevlous paragraph, the surface charge of phospholipld vesicles was varled by changing the amount of negatively charged phospholipid (PS). However, in such an experimental set-up, it is not only the surface charge of veslcles that $1 \mathrm{~s}$ changed, but there is also a varlation of the number of negatively charged phospholipld molecules avallable for interaction with coagulation factors. To study the effect of the surface charge of phospholipld vesicles on their activity in prothrombin activation (wlthout changing the amount of negatively charged phospholipid) the electrostatic potential of vestcles was varied by introduction of stearylamine in the membrane surface. Stearylamine $\left(\mathrm{CH}_{3}-\left(\mathrm{CH}_{2}\right)_{17}-\mathrm{NH}_{2}\right)$ is a primary amine, with large hydrocarbon chain, that is positively charged at physlological $\mathrm{pH}(\mathrm{pK} \sim 10.5)$, and which rapldiy incorporates into phospholipld bilayers. Since under the experimental condtions phosphatidylserine has a net charge of -1 , the introduction of each molecule of stearylamine in a membrane compensates the charge of one phosphatidylserine molecule.

Surprisingly, the incorporation of amounts of stearylamine up to 15 mo1\% In vestcles wth 5 mol $\%$ phosphatidylserine hardly affected their activity in prothrombin activation by the complete prothrombinase complex (Flg. 2). Between 0 and 12.5 mol stearylamine there was no detectable effect on the prothrombin-converting activity of the veslcles. Membranes with 15 mol \% stearylamine showed a minor loss of their ablithy to promote prothrombin activation. Also $\mathbb{i n}$ coagulation tests (Stypven time or Activated Partial Thromboplastin Time, APTT), vesicles containing 5 mol \% phosphatidylserine wth or without $15 \mathrm{~mol} \%$ stearylamine were almost equally effective in shortening the clotting time (data not shown).

Electrophoretic analysis showed that phosphatidylserine-containing vesicles with varying concentrations of stearylamine had electrophoretic 


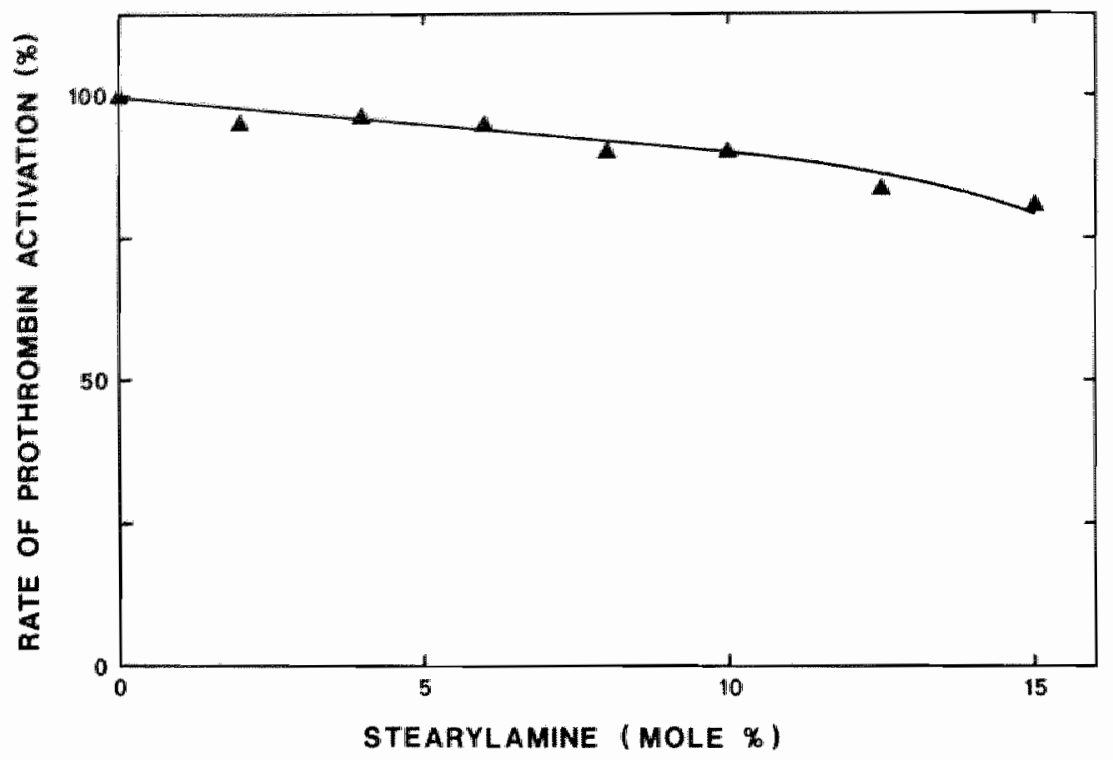

F1g. 2. Effect of stearylamine on the prothrombin-converting activity of phospholipid vesicles containing 5 mol 7 phosphatidylserine. Prom thrombin $(0.5$ uM) was activated in a reaction mixture containing 50 $\mathrm{mM}$ Tr1s-HC1 ( $\mathrm{pH} 7.9$ ), $175 \mathrm{mM} \mathrm{NaCl}, 5 \mathrm{mM} \mathrm{CaC1}, 0.5 \mathrm{mg} / \mathrm{ml}$ ovalbumin, $50 \mu \mathrm{M}$ phosphollpid, $1 \mathrm{pM}$ Factor $\mathrm{Xa}$ and 5 nM Factor $\mathrm{Va}$. The phospholipid vestcles contained 5 mol \% phosphatidylserine, 95 mol\% phosphatidylcholine and amounts of stearylamine indicated in the figure. When stearylamine was present the amount of phosphatidylchollne in the membranes was decreased by $1 \%$ per $3 \%$ stearylamine. Rates of prothrombin activation were determined as described in the experimental procedures. $100 \%$ corresponded with a rate of 2320 moles prothrombin activated per min per mol Factor Xa.

mobllitles that corresponded with their calculated surface charge (Fig. 3 ). Vesicles wh amounts of stearylaulne less than 6 mol \% were negatively charged, since they moved towards the anode, while vestcles with mol fractions of stearylamine exceeding 6 mol \% moved towards the cathode which indlcates that they had a positive electrostatic potential.

From these experiments it is obvious that membranes active in prothrombin activation do not have to possess a net negative charge. Membranes with positive electrostatic potentlal are able to promote prothrombin activation provided that they also contain phospholiplds ith negatively charged head group. 


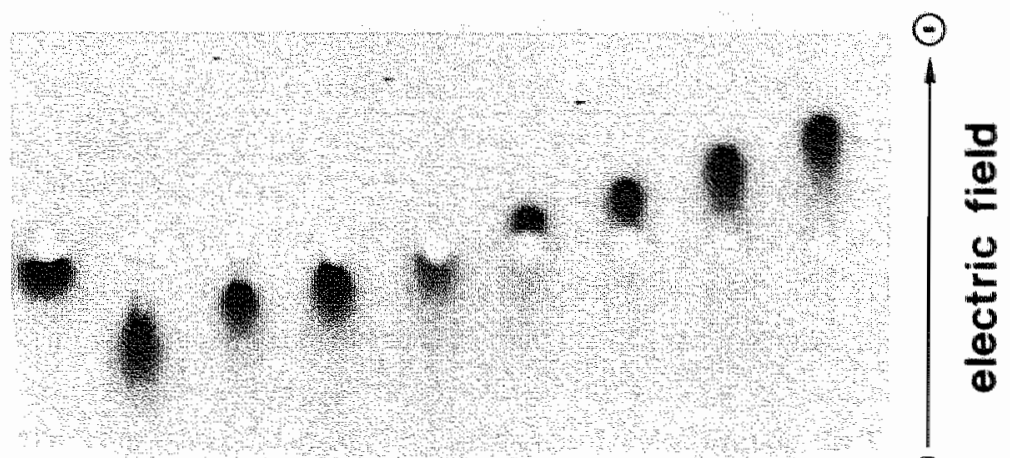

$\begin{array}{lllllllll}\text { PC } & 0 & 2 & 4 & 6 & 8 & 10 & 12.5 & 15\end{array}$

$\oplus$

STEARYLAMINE (MOLE $\%$ )

Fig. 3. Electrophoresis of phospholiptd vesicles containing varying amounts of stearylamine. "The phospholipld vesicles used $1 \mathrm{n}$ the experiment presented in FIg. 2 were subjected to agarose gell electrophoresis as described in the experimental procedures. For comparison, noncharged vesicles composed of $100 \%$ phosphatidylcholine (Indicated in the flgure by PC) were also electrophoresed. After electrophoresis, the vesicles (containing amounts of stearylamine lndicated in the flgure) were made visible by stalning with a saturated solution of lodine in water/ethanol $(95 / 5 ; \mathrm{w} / \mathrm{w})$.

The effect of stearylamine on the kinetic properties of phosphatidylserine-contalning membranes. Since prothrombin activation by the complete prothrombinase complex 18 already stimulated by membranes with very low phosphatidylserine content (FIg, 1), it has to be ruled out that the procoagulant activity of the phospholipid vesicles with posttive electrostatic potential is due to a contamination by a small amount of vesicles with net negative charge. To exclude such an artifact, stearylamine contalning vesicles (PS/PC/stearylamine, 5/90/15; mole/mole/mole) were subjected to agarose gel electrophoresis, eluted from the gel, and subsequently compared with non-electrophoresed vesicles and vesicles whout stearylamine ( $P S / P C, 5 / 95$; mole/mole) with respect to their ability to promote prothrombin activation.

Fig. 4 shows the effect of variation of the concentration of different kind of phospholip1d vestcles on the rate of prothrombin activation by the 


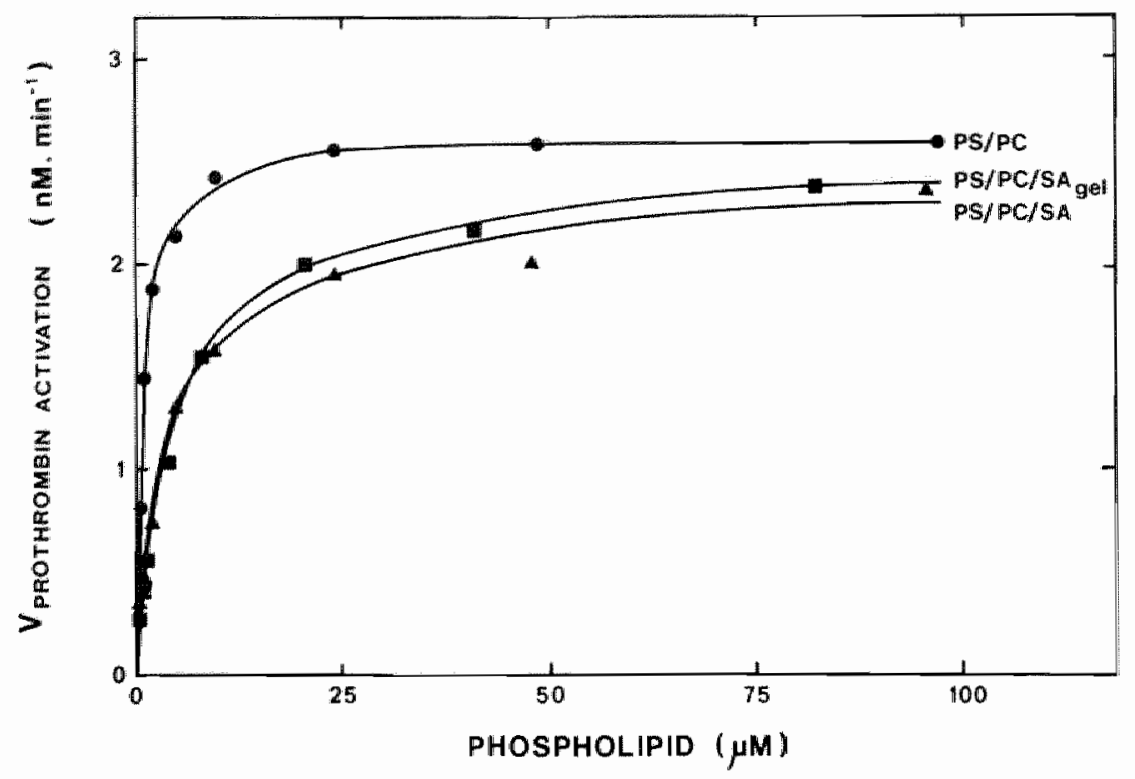

F1g. 4. Effect of the phospholipld concentration on prothrombin activation by the complete prothrombinase complex. Prothrombin (2 $\mu \mathrm{M})$ was activated in a reaction mixture containing $50 \mathrm{mM} \operatorname{TrIs}-\mathrm{HCl}(\mathrm{pH} 7.9)$, $175 \mathrm{mM} \mathrm{NaCl}, 5 \mathrm{mM} \mathrm{CaCl}, 0.5 \mathrm{mg} / \mathrm{ml}$ ovalbumin, $1 \mathrm{pM}$ Factor Xa, $5 \mathrm{nM}$ Factor Va and amounts of phospholipld Indicated in the filgure. The phospholipld preparations used in this experiment were: vestcleg: contalning phosphatidylserine and phosphatidylcholine in a molar ratio 5/95 (- - ), vestcles containing phosphatidylserine, phosphatidylcholine and stearylamine in a wolar ratio $5 / 90 / 15$ (A-A) and the same vesicles after agarose gel electrophoresis and elution from the gei (D-m). Rate: of prothrombin activation were determined as described in the experimental procedures.

complete prothromblnase complex. When procoagulant membranes do not contain atearylamine, rather low concentrations of phospholipld (PS/PC, 5/95; mole/ mole) were required to saturate the prothrombin-converting activity of the prothromblnase complex. Half maximal rates af prothrombin activation were obtalned at $0.8 \mu \mathrm{M}$ phospholipid. Upon introduction of 15 mol \% stearylamine in the vesicles, considerably more phospholipid was required for saturation of the prothrombinase complex. With stearylamine-containing vesicles, half maxtmal rates of prothrombin activation were obtalned at $4 \mu \mathrm{M}$ phospholipid. In this expertment, it was not possible to distingulsh electrophoresed from. 
non-electrophoresed stearylamine-contalning vesicles, since both phospholipid preparations produced identical saturation curves (FIg. 4 ).

We also attempted to determine the effect of stearylamine on the number of procoagulant sites present on vesicles. To this end, rates of prothrombin activation were measured at low phosphollpld and high prothrombin concentration as a function of the amount of Factor Xa-Wa complex. Under such conditions, rates of prothrombin activation are limited by the concentration of phospholipld-bound Factor Xa-Va. From the prothrombin activation rates, abtained at saturating Factor Xa-Va concentrations, one can calculate the concentration of membrane-bound Factor Xa-Va complex (see below).

Fig. 5A shows the effect of various amounts of Factor Xa-Va on the prothrombin-converting activity of veslcles with and without stearylamine. The typlcal hyperbollc titration curves are Indicative for equilibrium
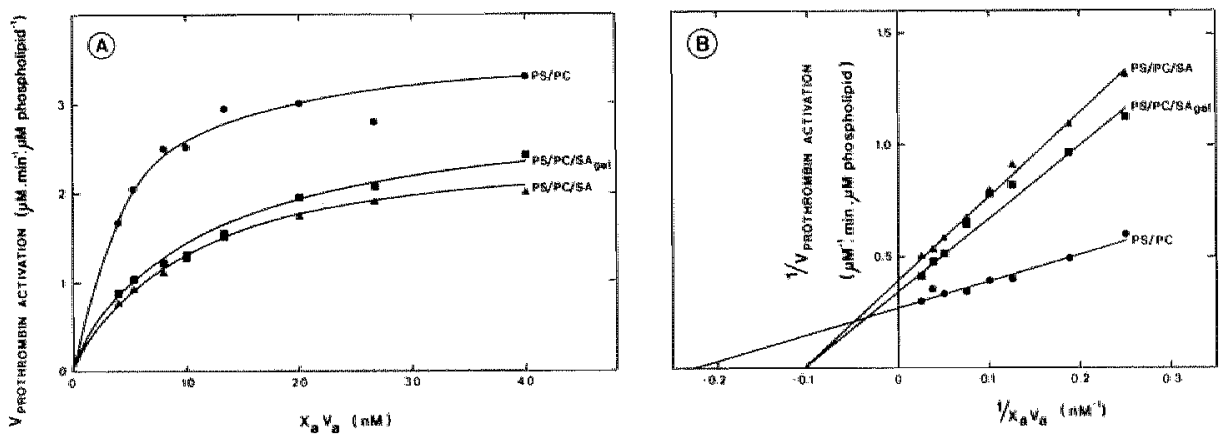

Fig. 5. Prothrombin activation on various kinds of phospholipld vesicles as function of the Factor $X a-V a$ concentration. Prothrombin ( $4 \mu M)$ was actiwated in a reaction mixture containing 50 mM Tris-HCl (pH 7.9), $175 \mathrm{mM} \mathrm{NaCl}, 5 \mathrm{mM} \mathrm{CaCl}, 0.5 \mathrm{mg} / \mathrm{ml}$ ovalbund amounts of Factor Xa and Factor Va indicated in the flgure, and $0.49 \mu \mathrm{M}$ phosphollpld vesicles (PS/PC, 5/95; mole/mole;-e), or $0.48 \mu \mathrm{M}$ phospholipid vestcles (PS/PC/stearylamine, $5 / 90 / 15$; mole/mole/mole;A-A), or 0.82 $\mu M$ of the same vesicles eluted from an agarose gel after electrophoresis (PS/PC/stearylamine, 5/90/15, mole/mole/mole; D-D). Rates of prothrombin activation were determined as described $\mathbb{1 n}$ the expertmental procedures and expressed as $\mu M$ prothrombin activeted/min/ $\mu M$ phospholipid, in order to compare the different phospholipld preparations. (A) direct plots of the rate of prothrombla activation as a function of the concentration of Factor Xa-Va complex. (B) double reciprocal plots of the same data. 
Baturation of procoagulant sites with the Factor Xa-Va complex. More quant1tative information can be obtained from double reciprocal plots of these data ( $1 \mathrm{~g}$. 5B). The intercepts at the ordinate and abcissa of such plots yleld, respectively, the rate of prothrombin actlvation at saturating concentrations of Factor Xa-Va (Vsat), and the concentration of Factor Xa-Va complex required for $50 \%$ saturation of the avallable procoagulant sites $\left(\mathrm{K}_{1}\right)$. From the rate of prothrombin activation at saturating concentrations of Factor Ka-Va one can subsequently calculate the number of functionally active Factor Xa-Va complexes (procoagulant sites) on the phospholipid surface (eq. 1):

In wheh the number of sites is expressed as moles Factor Xa-Va complex bound per of phospholipld, Vsat is the rate of prothrombin activation ( $\mu M$ prothrombin actlvated/min/ MM phospholipid) at saturating Factor Xa-Wa concentrations (FIg. 5B) and $V \max$ is the turnover number of the prothrombinase complex ( 3000 moles prothrombin activated/min/mol Factor Xa-Va; ref. 3).

Table I summarizes the effect of stearylamine on the "binding parameters" of phospholipid vesicles for Factor Xa-Va. Veslcles without stearylamine (PS/PC, 5/95; mole/mole) were able to bland $1.05 \times 10^{-3}$ moles of Factor Xa-Va complex per mol of phospholipid with a $k_{3}$ of $4.4 \times 10^{-9} \mathrm{M}$. Introduction of 15 nol stearylamine in these vesicles hardly affected the number of blnding stes and the binding affinity for the Factor Xa-Va complex. There was a amall increase of the $K_{4}$ to $9.5 \times 10^{-9} \mathrm{M}$ and the number of procoagulant sites was silighty decreased $\left(0.73 \times 10^{-3}\right.$ moles Factor Xa-Va bound per mol of phospholfpid). Stearylamine-containing vesfcles that were subjected to gel electrophoresis and that were eluted from the gel had the same binding parameters as the non-electrophoresed vesicle preparation.

From these experiments we conclude that a) the prothrombin-converting activity of membrane preparations with stearylamine (PS/PC/stearylamine, 5/90/15; mole/mole/mole) cannot be due to the presence of a sma11 amount of negatively charged phospholipld vesticles, and b) an excess of stearylamine hardly affects the binding properties of the procoagulant sites on phosphatidylserine-contalning membranes. 
Table I

Effect of tearylamine on the binding of the Factor Xa-Va complex to
phospholipld vesicles

The binding parameters ( $K_{1}$ and number of binding sltes) were obtalned from the double reciprocal plot's presented in Fig. 5B.

$$
4.4 \times 10^{-9} \quad 1.05 \times 10^{-3}
$$

$\mathrm{PS} / \mathrm{PC} /$ stearyl amine

(5/90/15, mole/mole/mole)

$$
9.5 \times 10^{-9} \quad 0.73 \times 10^{-3}
$$

PS/PC/stearylamine(gel eluted)

$9.5 \times 10^{-9}$

$0.84 \times 10^{-3}$

(5/90/15, mole/mole/mole)

Effect of stearylamine on the prothrombin-converting activity of membranes with different anionic phospholipids. In order to test whether the small effects of stearylamine on the prothrombin-converting activity of phospholipid is a unique property of membranes with phosphatidylserine, we also determined the effect of stearylamine on the procoagulant activity of phospholipid vesicles containing other antonic phospholipids. The chemical structures of the antonic phospholipids used in this expertment are presented in Fig. 6. The net charge carried by these phospholipids is

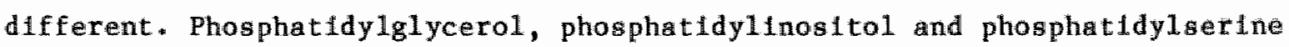
have a net charge of -1 (phosphatidylsertne carries one postelve and two negative charges), phosphatidic acid contains elther one or two negative charges $\left(\mathrm{pK}_{2} \sim 7\right)$, whlle phosphatidyl- $\beta$-lactate carries two negative charges. The latter phospholipid is of partlcular 1nterest, since it structurally resembles phosphat1dylserine. Phosphatidylsertne and phosphat 1 dy $1-\beta-1 a c t a t e$ only differ by the presence of a $\mathrm{NH}_{2}-$ group $\left(-\mathrm{NH}_{3}{ }^{+}\right.$at phystological pH) in phosphatidyl serine.

Table II summarlzes the effect of excess of stearylamine (15 mo $1 \%$ ) on the prothrombin-converting activity of membranes containing 5 mol $\%$ of the various anionlc phospholiplds. Without stearylanine present, the anlonic phosphollpids differed already considerably in thelr ability to promote 
<smiles>[X]OP(=O)([O-])OCC(COC([R])=O)OC([R])=O</smiles>

$$
-x=-H \quad P A \quad(1-\text { or } 2-)
$$<smiles>CCC(C)C(=O)[O-]</smiles>

Plac

INOSITOL

PI

GLYCEROL

PG

F1g. 6. Chemlical structures of anionic phospholipids. The prothrombin-converting activities of membranes contalning the antonic phospholipids presented in this figure were compared in the experiment described in Table II.

Table II

\section{Effect of stearylamime on the prothrombin-converting activity of membranes containing different antonic phospholiptds}

Prothrombin $(0.5 \mu \mathrm{M})$ was activated in a reaction mixture containing $50 \mathrm{mM}$ Tris-HCl ( $\mathrm{pH} 7.9$ ), $175 \mathrm{mM} \mathrm{NaCl}, 5 \mathrm{mM} \mathrm{CaCl}, 0.5 \mathrm{mg} / \mathrm{ml}$ ovalbumln, $50 \mu \mathrm{M}$ phosphollpld, $5 \mathrm{pM}$ Factor Xa and $5 \mathrm{nM}$ Factor Va. Veslcles without steary1anline contalned 95 mol \% PC and 5 mol \% anionic phospholipld; vestcles with stearylanine contalned $\mathrm{PC}$, anionic phospholipid and stearylamine in a molar ratto $90 / 5 / 15$. Rates of prothrombln activation were determined as described in the experimental procedures.

\begin{tabular}{lccc}
\hline Phospholipid & \multicolumn{2}{c}{$\begin{array}{c}\text { Prothrombin activation (nM/min) } \\
\text {-stearylamine }\end{array}$} & $\begin{array}{c}\text { Inhition } \\
(\%)\end{array}$ \\
\hline PS/PC & 10.6 & 8.8 & 17 \\
PA/PC & 6.8 & 1.1 & 84 \\
PLac/PC & 2.3 & 0.21 & 91 \\
PG/PC & 0.36 & 0.022 & 94 \\
PI/PC & 0.29 & 0.017 & 94 \\
\hline
\end{tabular}


prothrombin activation. The procoagulant activity of the membranes decreased In the order phosphatidylserine $>$ phosphatidic acld > phosphatidy1- $\beta$-1actate $>$ phosphatidy1glycerol > phosphatidylinositol. Upon incorporation of stearylamine all membranes retalned at least part of their activity in prothrombin actiwation. However, the effects of stearylamine on the prothrombln-converting activity was much more pronounced on membranes contalming anionic phospholipids other than phosphatidylserine. Vesicles with phosphatidic acid were inhibited by stearylamine for some 80\%, while the Incorporation of stearylamine in vestcles with phosphatidy1- $\beta$-lactate, phosphatidylglycerol or phosphatidylinositol inhibited their prothrombinconverting activity more than $90 \%$. Apparently, stearylamine has more effect on the prothrombin-converting activity of membranes, which by itself already have a decreased activity in prothrombin activation and a low affinity for coagulation factors (27).

Table II contains a few other observations that need further atcention. The data presented in this table show that there is no direct relation between the procoagulant activity of membranes and the surface charge provided by their antonic phospholiplds. Vestcles containing 5 mol \% phosphatidy1- $\beta$-lactate or 5 mol \% phosphatidic actd, which have a higher surface charge than vesicles with 5 mole $\%$ phosphatidylserine are less active in prothrombin activation. In this respect the difference between phosphatidy $1-\beta-1$ actate and phosphatidylserine may be of speclal interest. Since these phospholiplds only structurally differ by the presence of an amino group in phosphatidylserine, their different procoagulant activities are indicative for an important function of this amino group in the lnteractions with the proteins of the prothrombinase complex.

\section{DISCUSSION}

The results obtained in this study provide information that w11 be relevant to understand the chemical and physical requirements of phospho11pid membranes, which promote the activity of the prothrombinase complex. In this paper $1 t$ is shown that a) such membranes have to contain negatively charged phospholfpids, b) there is no obvious relation between the surface charge of membranes and their activity in prothrombin activation, c) there 
1. no requirement for a negative surface charge, since membranes ith positive electrostatic potential exhlbit considerable prothrombin-converting activity, and d) membranes wth phosphatidylserlne are much more active than membranes wh phosphatidyl-b-1actate, which is indicative for an important function of the amino group of phosphatidylserine in the interaction with coagulation factors.

Conflicting wews exist as to the chemlcal and physlcal nature of the calcium-dependent interaction between vitamin $\mathrm{K}$-dependent coagulation factors and the negatively charged head groups of anionic phospholipids in procoagulant membranes. Dombrose et $a 1$. (28) reported that the blnding of prothrombin fragment 1 (the $y$-carboxyglutamic acid-containing activation fragment of prothrombin) to phospholipld vesicles composed of phosphatidylglycerol and phosphatidylcholine is highly ionic strength dependent. Based on this observation they proposed that electrostatic Interactions BIgniflcantly contribute to protein-membrane assoclation. In a hypothetical model the binding of prothrombin fragment 1 to membranes was visuallzed as follows. Prothrombin fragment 1 itself is negatively charged. When calcium lon bind to the $\gamma$-carboxyglutamic acid resldues of fragment 1 , 1 t becomes positively charged and will be electrostatically attracted by the negatively charged phospholipld surface. The assoclation of prothrombin fragment 1 with calcium Ions (1.e. its change from negative to positive charge) is promoted by the fact that in the vicinity of the negatively charged phospholipid surface there is a calcium Ion gradient with greatly Increased local calcium concentration near the membrane surface.

Resnfick and Nelsestuen (29) showed that the binding of prothrombin to membranes containing phosphatidylserline and phosphatidylcholine (PS/PC, 20/80; mole/mole) was rather insenstitive to variation of $\mathrm{pH}$ and lonic strength. Based on this observation they proposed a chelation model for prothrombin-membrane binding. In this model, calclum lons are thought to form a coordination complex with the two carboxylgroups of $p$-carboxyglutamic acld in prothrombin and two negative charges supplied by antonic phosphollplds of the membrane surface.

We feel that our results are consistent with a chelation model. The obgervation that a change of the surface charge of phosphatidylserinecontaining vestcles from a negative to a positive potential hardly affects their activity in prothrombin activation, indicates that in this case 
electrostatic Interactions have 11tte contribution to proteln-membrane assoclation. It cannot be ruled out, however, that such interactions may be more important for protein binding to membranes contaluing antonlc

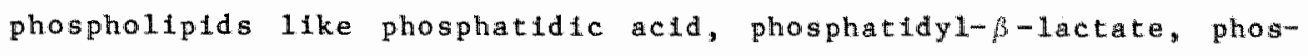
phatidylglycerol or phosphatidylinositol. Constdering the chelation model to be applicable to membranes with phosphatidylserine we propose that the amino group of this phospholipid functions as a ligand in the chelate complex. Assuming the participation of a hypothetical ligand $x$, for instance supplied by the protein, it becomes posstble to obtain an octahedral structure (cf. Ca-EDTA complex) with the two carboxyl groups of $p$-carboxyglutamic acid and the phosphate, amino and carboxyl groups of phosphatidylserine (F1g. 7). It is likely that such a complex wth 6 coordination bonds has an increased stablity which can explain why membranes with phosphatidylserine have such excellent procoagulant properties. This may also have physlological slgnificance since phosphatidylserine is the major anlonic phosphollpid in blood platelets and endothellal cells, the membranes of which are thought to stimulate coagulation in situ*

Fig. 7. Hypothetical model for chemical interactions involved In $\mathrm{Ca}^{2+}$-dependent binding of vitamin $\mathbb{K}$-dependent proteins to procoagulant membranes.

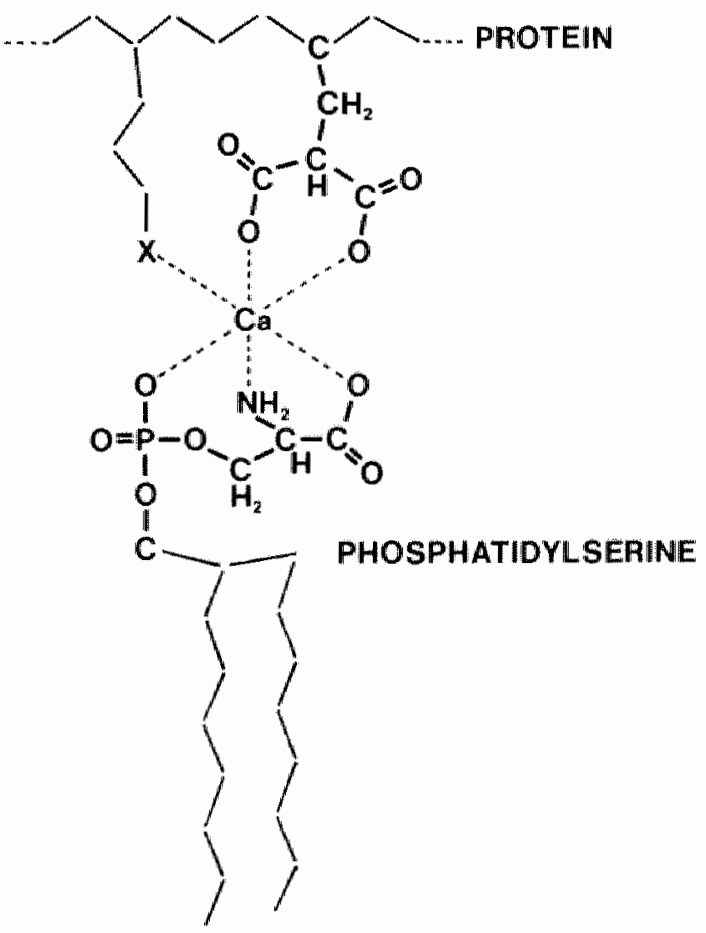


TEERERCBS

1. Roslng, J., Tang, G., Govers-Riemslag, I.W.P., Zwaal, R.F.A. and Hemker, H.C. (1.980) J. BHol. Chem. 255, 274-283.

2. Pusey M.L. and Nelsestuen, G.L. (1.983) BLachem. Blophys. Res Comm. 114, $526-532$.

3. van Rifn, J.L.M.L., Govers-Rlemslag, J.W.P., Zwaal, R.F.A. and RosIng, J. (1984) Blochenlitry $23,4557-4564$.

4. Neshelin, M.E., Tracy, R*P. and Mann, K.G. (1984) J. Biol. Chem. 259, $1447-1453$.

5. Neghe1m, M.E., Taswe11, J.B. and Mann, K.G. (1979) J. Biol. Chem. 254 , 10952-10962.

6. Joblin F and Esnouf, M.P. (1967) Blachem. J. 102, 666-674.

7. Hemker, H.C., Esnouf, M.P., Hemker, P.W., Swart, A.C. and MacFarlane, R.G. (1967) Nature 215, 248-251.

8. Bloom, J.h., NesheIr, M.E. and Mann, K.G. (1979) Blochem1stry 18, 4419-4425.

9. Pusey, M.L., Mayer, L.D., We1, G.J., Bloomfleld, A. and Nelsestuen, G.L. (1982) Blochenistry 21, 5262-5269.

10. van de Waart, P., Bruls, H., Hemker, H.C. and Lindhout, T. (1983) Biochemistry $22,2427-2432$.

11. Stenflo, J., Fernlund, P., Egan, W. and Roepstorff, P. (1974) Proc. Nat. Acad. Sci. 71, 2730-2733.

12. Nelsestuen, G.L., Zytkovicz, T.H. and Howard, J.B. (1974) J. Biol. Chem. $249,6347-6350(1974)$.

13. Bucher, D., Nebel1n, E., Thomsen, J. and Stenflo, J. (1976) FEBS Lett. $68,293-296$.

14. Bangham, A.D. (1961) Nature 192, 1197-1198.

15. Papahad fopoulos, D., Houg 1e, C. and Hanahan, D.J. (1962) Proc. Soc. Exp. B101. Med. 111, 412-416.

16. Owen, W.G., Esmon, C.T. and Jackson, C.M. (1974) J. Biol. Chem. 249, $594-605$.

1.7. Fufikawa, K., Legaz, M.E. and Davie, E.W. (1972) Biochemistry 11, $4882-4891$.

18. Fuflkawa, K., Legaz, M.E. and Davle, E.W. (1972) Blochenlstry 11, $4892-4899$.

19. Lindhout, T., Govers-RIemslag, J.W.P., van de Wart, P., Hemker, H.C. and Rosing, J. (1982) Biochemistry 21,5495-5502.

20. Comfurlus P. and Zwaal, R.F.A. (1977) Biochim. Blophys. Acta 488, 36-42.

21. de Krulffe, B., Cull1s, P.R. and Radda, G.K. (1975) Blochim. Blophys. Acta $406,6-20$.

22. Buttcher, C.J.F., van Gent, C.M. and Pries, C. (1961) Ana1. Chim. Acta $24,203-207$.

23. Ward, M.W.N., Owens, C.W.J. and Rennte, M.J. (1980) C1In. Chem. 26, $1336-1339$.

24. Chase Jr. $\mathbb{T}$. and Shaw, $\mathbb{E}$. (1969) Blochemistry 8, 2212-2224.

25. Smith, R.L* (1973) J. B1o1. Chem. 248, 2418-2423 (1973).

26. Denson, K.W.E. (1976) in Human Blood Coagulation, Haemostasts and Thrombosis (R. Blggs, ed.), 655-750 (Blackwell Scientific Publications, Ox ford).

27. Nelsestuen G.L* and Broderius, M* (1977) Biachemistry 16, 4172-4181.

28. Dombrose, F.A., Gite1, S.N., Zawalich, K. and Jackson, C.M. (1979) J. B101. Chem. 254, 5027-5040.

29. Resulick R.M. and Ne1sestuen, G.L. (1980) Blochemistry 19, 3028-3033. 
CHAPTER VI

GENERAL DISGUSSION

The converston of prothrombin to thrombin by Factor $X a$ is a very slow process which is accelerated enormously in the presence of a phospholiptd surface, calcium lons and the protein cofactor Factor Val Kinetic experiments have shown that phospholipids exert their effect by drastically decreasing the $\mathrm{Km}$ for prothrombin, while the mafor effect of Factor $\mathrm{Va}$ is a thousand-fold increase of the $k_{c a t}$ of prothrombin activation. on membranes with a low affinty for prothrombtn, Factor Va also causes an additional decrease of the $\mathrm{Km}$ for prothrombin. Little information on the molecular interactions responsible for these effects is, however, available. In this thesls experiments are described that aln to further elucldate the interactions of the components involved in prothrombin activation.

Prothrombin conversion proceeds by phospholipld-bound Factor Xa or, lf Factor Va is present, by phospholipid-bound Factor Xa-Va complex. It appears that prothrombin activation in the absence or presence of Factor Va cannot be described by a single model (1). Without Factor Va, the density of prothrombin bound at the phospholipid surface determines the reaction kinetics (bound substrate mode1), while in the pregence of Factor Va the reaction rate is governed by the prothrombln concentration in free solution (free substrate mode1).

The experiments presented in chapter II are consigtent with these observations. In the absence of Factor Va, the prothrombin fraginents, fragment 1 (F 1) and fragment 1.2 (F 1.2), are efflclent Inhibtors of prothrombin activation. The fragments apparentily compete with prothrombin and Factor Xa for binding sites at the phospholipid surface, which will result in reduction of the amounts of enzyme and substrate participating in prothrombin conversion. These results can be easily explained in the bound substrate model. However, when Factor $\mathrm{Va}$ is present, the activation peptides are much less effective in reducing the rate of prothrombin conversion. This result is consistent with the vlew that factor va promotes 
the assembly of the prothromblnase complex through interactions with Factor Xa and prothrombin that are independent of their membrane binding domain, which explating why the fragments do not interfere with these interactions" In some experlments the prothrombln fragments even stimulate the reaction, Indfatelng that wh the complete prothromblnase complex the free substrate model is indeed applicable. Recently, it was shown by Forman and Nemerson (2) that prothrombin fragment 1 also stimulates the activation of Factor $\mathrm{X}$ via the tissue factor pathway. This observation was also taken as support for a mechanism in which soluble substrate (in this case Factor $X$ ) directly interacts with a surface-bound catalytic unit.

Two models have been proposed to explain the obserwation that Factor va conslderably decreases the $\mathrm{Km}$ for prothrombin activation on membrames with a low affinity for prothrombin. A Factor Va induced clustering of phosphatidylserine molecules, as reported by Mayer and Nelsestuen (3), may create a better surface for prothrombln binding and hence causes a decrease of the Km. We would expect, however, that with such a mechandsm both $\mathrm{F} 1$ and F 1.2 would be efficient lnhibitors of the complete prothromblnase complex on low affinity membranes, which is apparently not the case. It is also possible that Factor Va promotes binding of prothrombin to the prothrombinase complex by direct interaction with the prothrombin fragment 2 region (4). Such an enhanced binding affinlty can be correlated with the Factor Va-induced decrease of the $\mathrm{Km}$ for prothrombin. Thls $1 \mathrm{~s}$, however, not supported by our results, since in none of the experiments $F 1.2$ is a better Inhibitor than F 1 . Because mone of the existing hypotheses fits our data an alternative explanation for the effect of Factor Va on the Rm for prothrombin is glven in chapter IT. It Is known that Factor Va Increases at least one limfting forward rate constant of prothrombin activation (5). Since the $\mathrm{Km}$ for prothrombin is a complex function of dissociation constants and forward rate constants, we propose that the ralse of a rate constant may also decrease the $\mathrm{km}$ for prothromb1n. In that case it is not to be expected that the activation fragments will inhibit prothrombin activation, since they can only interfere with direct binding interactlons and not with the individual steps in the reaction mechanism.

More Information on the mechanism of prothrombln activation and the rale of the accessory components can be obtained by studying snake venom prothrombin activators. Snake venom activators can have widely different 
structural and functional properties and may, therefore, add to our knowledge of the mode of action of the physlologtcal activator, factor Xa. In Chapter III we describe the purffication and charactertation of the prothrombin activator from the venom of oxyuranus scutellatus. The venom activator was purffied by gel filtration and ion-exchange chromatography. The enzyme has a molecular welght of about 300,000 and consists of subunits of $M_{r} 110,000,80,000$ and two disulfide-1inked polypeptides of $M_{r} 30,000$. One or both of the $M_{r} 30,000$ subunits contain the active site. Prothrombin activation by the venom enzyme is greatly stimulated by phosphollpids plus callctum lons, but is not affected by the presence of Factor Va. Several experiments indicate that the activator has many properties in common with the Factor Xa-Va complex, and suggest that the enzyme is a multimeric protein, consisting of a catalytic unit with Factor Xa-like activity and a cofactor part, which functions like factor Va. The catalytic unit lis probably formed by the two $M_{r} 30,000$ subunlts, while the cofactor conslsts of the $M_{r} 110,000$ and 80,000 subun1ts.

The forces responsible for the interaction of the catalytic domaln and the cofactor part are not yet clear. It is possible that hydrophoblic Interactions are important, since treatment of the activator with NaSCN results in a rapid loss of prothrombin-converting activity, while amidolytic activity towards the chromogenic substrate $\$ 2337$ remalns unaffected. Bovine Factor Va can partly restore the activity of the NaSCN-treated activator preparation, Indlcating that elther a separation of the two functional domalns of the activator (1.e. catalytic and cofactor unit) or denaturation of the cofactor part did occur upon NascN-1nduced inactivation.

We have as yet no information on the biading interaction of the venom proteln with phospholiplds. It 1 s, however, interesting to mention that the venom activator contains $p$-carboxyglutamic acld residues which may be involved in the calclum-mediated binding of the enzyme to phospholipid surfaces.

Finally, amino acld sequence analysis of the activator and comparison with known sequences of Factor Xa and Factor Va should revieal if the venom activator indeed shares significant sequence homology with these protelns. If homologies exist, such a study may give relevant information on functional domains in the mammallar proteins. 
The purifted prothroibin activator from oxyuranus scutellatus was employed in studies on the properties of the platelet procoagulant sites. platelets, particularly if activated, have the ability to promote the assembly of the prothrombin- and Factor X-activating complexes and thus enhance the rate of coagulation factor activation. The chemical nature of the procoagulant 1 tes $18 \mathrm{st} 11$ a matter of debate: they may efther consist of specific receptor proteins or be composed of anionic platelet phospholiplds. With respect to the last posslbility an Important function of phosphatidylserine in the procoagulant sites has been suggested. This phospholipld is located almost exclusively in the cytoplasmic leaflet of the plasma membrane of resting platelets. Upon stlmulation of the platelets wth collagen plus thrombin the phosphatidylserine is thought to be translocated by a so-called "flif-flop" mechanlsm to the outside half of the membrane, thereby ralsing the procoagulant activity of the platelets (6).

In chapter IV it 1 s shown that platelets also promote the prothrombinconverting actlivty of the venom activator from oxyuranus scutellatus. When platelets are stimulated with collagen plus thrombin they are about twenty times more actlve than unstimulated platelets in supporting venom-catalyzed prothrombin activation. A number of observations indicate that the venom activator and the Factor Xa-Va complex recognize the same procoagulant sites on the platelet surface. The venom activator and Factor Xa-Va complex equal1y wel1 probe the generation of a procoagulant surface upon platelet stimulation with various triggers. Also the time course of appearance of platelet prothrombin-converting activity is ldentical for both activators. Furthermore, the number of procoagulant sttes on the platelet surface is about the same for the venom enzyme and Factor Xa-Va complex. The involvement of platelet phospholipids $1 \mathrm{~s}$ emphasized by the effect of phosphollpase $A_{2}$ treatment of the platelets. Incubation of platelets with phospho1lpase $A_{2}$ causes degradation of phosphollplds exposed at the outside of the membrane and leads to a rapid decrease of platelet procoagulant activity as probed with Factor Xa-Va or with venom enzyme. These results argue agalnst the involvement of spectfic receptor proteins in the assembly of prothrombinase complex at the platelet surface, since it is unlikely that the venom prothrombin activator would recognize such a receptor. We are aware that this evldence is not conclusive since it cannot be excluded 
that the venom cofactor part may also have affinity for the proposed protein receptor site. It should be stressed, however, that the participation of protein receptors is not necessary to explatn our observations in kinetic experiments. Antonlc phospholiplds exposed in the outer leaflet of the platelet plasma membrane can equally well provide functional binding sites for a prothrombin-activating complex consisting of either Factor Xa-Va or venom enzyme.

The experiments reported in chapter $V$ are indlcative for a special role of phosphatldylserine (PS) in prothrowbin activation. Phosphatidylcholdne (PC) vesicles cantalning small amounts of es provide an excellent procoagulant surface, while other negatively charged phospholipids, such as phosphatidic acld (PA), phosphatidy1-B-lactate (PLac), phosphatidylglycerol. (PG) and phosphatidylinostol (PI), are less effective. Furthemore, the activity of vesicles with those anionle phospholiplds is very senstive to varlations of the surface charge. Incorporation of positively charged stearylamine in the vestcles, which reverses their surface charge, greatly affected prothrombinase activity, while such a charge reversal hardly affected the activity of PS-containing membranes. This result suggests that the prothrombinase activity of membranes which contain PS as anionlc phosphollpid is relatively independent of the surface charge of the vesicles. Thls seems to be in contrast with the experiments of Bangham (7) who demonstrated wh clotting assays that a negative surface potential is an absolute requirement for procoagulant activity. However, he used mixtures of PC and dicetylphosphate, an anionic lipld that structurally resembles $P G$ and PI in having one negative charge on the phosphate group and lacking other functional groups for interaction with calclum and/or coagulation factors. Therefore, 1 t 1 s possible that electrostatic interactions form an important contribution to the binding of coagulation factors to phospholiplds of this kind. Resnick and Nelsestuen (8) showed that prothrombla binding to $\mathrm{PS} / \mathrm{PC}$ membranes is relatively insensitive to changes $1 \mathrm{n}$ lonfc strength and $\mathrm{pH}$ when both the protein and the membrane are saturated th calcium. They suggested that prothrombin-membrane interaction lis accomplished by the formation of a mixed chelate complex fin which calctum is coordinated by 11 gands supplied by the protein and the membrane. Our results with PS/PC vestcles also show the importance of non-1onlt interactions and are, therefore, consistent with a chelation 
model. Compartson of the act1vity of PS and PLac, which differ only by the

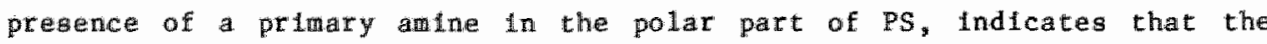
amino group of PS may have an important function in the formation of such a coordination complex. We propose that the amino group, together with the phosphate and carboxyl group, acts as a ligand to stablitze the complex. The possible particlpation of the amino group, whlch at neutral pH exists In the protonated form, 1s Indrectly supported by the observation that complexation of calclum by PS molecules results in the release of $\mathrm{H}^{+}$ $(9,10)$. Completion of the coordination sphere of the $\mathrm{Ca}^{2+}$ ion can be obtalned with 11gands supplied by the proteln. The formation of an octahedral complex may Involve two carboxyl groups of a Gla residue and an amino group of a baslc amino acid resldue, several of which are present in the membrane-binding domaln of vitamin $\mathbb{K}$-dependent proteins.

It $1 \mathrm{~s}$, howewer, not necessary that a11 Gla residues of vitamin $\mathrm{K}$-dependent coagulation factors are directly involved in proteln-membrane association. Some of the Gla residues particlpate in the stabllization of a calclum-induced conformational change of the proteins, which is a prerequistle for protein-membrane interaction (11). Prothrombin and prothrombin fragment 1 contain two or three high affintty calcium binding sites and several sites with lower affinity $(12,13)$. The high affintty sites consist of Gla residues that form an intramolecular bridge through a calcium Ion (14). Occupation of these sites is necessary for the protein transition which may subsequently render a line-up of lower affinity Gla-defined calclum binding sites, sultable for membrane interaction. Therefore, the function of the Gla resilues seems to be twofold. Some of then are Involved in a protein transition by complexing $\mathrm{Ca}^{2+}$ 1ons, while otherg may directly particlpate in membrane binding by forming a mixed calctum chelate together with 11gands from the membrane (15). The concept of two classes of metal-binding sites (16) is supported by the following observations. The proteln conformational change can be Induced by several divalent lons other then calclum, especlally $\mathrm{Mg}^{2+}, \mathrm{Mn}^{2+}$ and $\mathrm{Sr}^{2+}$ wons are effective (17). Proteln-membrane binding, rendering a functional active protein 1s, however, only supported by $\mathrm{Ca}^{2+}$ lons and, to a lesser extent, by $\mathrm{Sr}^{2+}$ and $\mathrm{Ba}{ }^{2+}$ tons, whlle $\mathrm{Mg}^{2+}$ and $\mathrm{Mn}^{2+}$ do not support association (17). The distinct cation specificlty may reflect differences in geometry of the two types of metal lon binding sites (cf. ref. 18). 
The maforlty of the prothrombln activation studies described in cheter $V$ were carried out with the complete prothrombinase complex and thus glve only partial information on the individual protein-membrane interactions. The results, however, suggest that varlation of the veslcle surface charge has minor effects on the membrane affinity for Factor Xa and prothrombln, but also for Factor Va. For the latter protein this seems to be Inconsistent with the observation that factor Va binding is highly ionfe strength dependent and is therefore thought to be electrostatic in nature. However, experiments by Pusey et al (19) show that variation of the lonic strength and of the PS content of the membrane only affects the dissociation of the Factor Va-membrane complex, but has a negligible effect on the assoclation between Factor Va and the membrane. These results led to a model that assumes that non-1onle forces are important for the initial assoctation of Factor $\mathrm{Va}$ wh the membrane. Stabilization of the binding Interaction presumably occurs by a subsequent clustering of PS molecules around the protein (3) which results in a further electrostatic attraction between a positively charged domain of Factor $V a$ and a highly negatively charged site at the membrane. Such a model can also explain why Factor Va can bind to PS-containling surfaces with net positive charge. Also on these surfaces Inftial non-ionic forces leading to membrane-proteln assoctation can be followed by the generation of PS-rIch domalns at the protein-1ipld interface, that stabilize the Factor Va-membrane complex.

Data are, however, lacking at this time to support these views. An extension of the kinetic studies and experinents to elucldate Individual protein-membrane interactions at net positively charged surfaces may glve valuable information as to which interactions are actually important for proper functioning of the prothrombinase complex.

\section{REFERENCES}

1. van RIJn, J.L.M.L, Govers-Riemslag, J.W.P., Zwaal, R.F.A. and Rosing, J. (1984) Blochemlatry 23,4557-4564.

2. Forman, S.D. and Nemerson, Y. (1986) Proc. Nat1. Acad. Sc1. USA 83, 4675-4679.

3. Mayer, L.D. and Nelsestuen, G.L. (1981) Blochemistry 20, 2457-2463.

4. van de Waart, P., Hemker, H.C. and LIndhout, T. (1.984) Blochemistry 23, $2838-2842$. 
5. Neshefm, M.E. and Mann, K.G. (1983) J. BLl. Chem. 258, 5386-5391.

6. Beverg, E.M., Rosing, J. and Zwal, R.F.A. (1987) in platelets in Blology and Pathology III (Macintyre and Gordon, eds.) 127-160, Rlacvier Sclence Publishers B.V. (Biomedica1 Division).

7. Bangham, A. D. (1961) Nature 192, 1197-1198.

B. Resnlek, M.M. and Nelsestuen, G.L. (1980) Blochemistry 19, 3028-3033.

9. Abramson, M.B. Katzmat, R. and Gregor, H.P. (1964) J. Blol. Chem. 239, 70.

10. Papahadjopoulos, D. (1968) Bloch1m. Biophys. Acta 163, 240-254.

11. Nelsestuen, G.L. (1976) J. B1al. Chem. 251, 5648-5656.

12. Furle, B.C., Mann, K.G. and Furie, B. (1976) J. Blol. Chem. 251, $3235-3241$.

13. Deerfle1d, D.W., Olson, D.L., Berkow1tz, P., Byrd, P.A., Koehler, K.A., Pedersen, L.G. and H1skey, R.G. (1987) J. Blol. Chem. 262, 4017-4023

14. Furie, B.C., Blumensteln, M. and Furle, B. (1979) J. Biol. Chem. 254, $12521-12530$

15. Lilm, T.K., Bloomfleld, V.A. and Nelgestuen, G.L. (1977) Biochemistry $16,4177-41.81$

16. Prendergast, F.G. and Mann, K.G. (1977) J. B1o1. Chem. 252, 840-850.

17. Nelsestuen, G.L., Broder1us, M. and Martin, G. (1976) J. Btol. Chem. $251,6886-6893$.

18. Somiterv11le, L.E., Resnick, R.M. "Thomas, D.D. and Ne1sestuen, G.L. (1986) J. Blo1. Chem. 261, 6222-6229.

19. Pusey, M.L., Mayer, L.D., Wel, G.J., Bloomfleld, V.A. and Melsestuen, G.L. (1982) Blachem1stry 21, 5262-5269. 
SUMARY

In this thesis a study on the mechanism of the Factor Xa-catalyzed conversion of prothrombin to thrombln is described. Prothrombin activation is studied both in model systems with purifled phospholiplds, as well as in the presence of blood platelets, the blood cells which under physiological conditions are thought to provide the procoagulant surface.

Durlng the conversion of prothrombin, the activation peptides fragment 1 and fragment 1.2 are generated. These peptides contaln the membrane binding domain of prothrombin. They have the ablitty to interfere with the assoclation of the various constituents of the prothrombinase complex with the membrane and are therefore potentlal inhibitors of thrombin formation. The experiments presented in chapter II show that both fragments indeed effectively inhibit prothrombin activation at the membrane surface. However, Factor Va protects agalnst inhibltion, indicating that in the presence of this cofactor prothrombin conversion proceeds vla a different mechanism.

Prothrombin activation may also be catalyzed by snake venom proteins. In chapter III the purffication and characterization of the prothrombin activator from the venom of oxyuranus scutellatus (Talpan snake) is described. The prothrombin activator present in the venom of this snake is a multimeric protein conslsting of a catalytic unit, showing similarities with Factor Xa, and a cofactor part, whlch functions like Factor Va. Prothrombin activation by the venom actlvator is greatly enhanced by phospholipids plus calclum, but not by Factor Va.

The snake venom activator is subsequently used to characterize the procoagulant sites on the platelet surface. Hunan platelets stimulate the activity of the enzyme. The resultg presented in chapter IV suggest that Factor Xa-Va complex and the snake venom activator recognllze the same procoagulant sites on the platelet surface and that anionic phospholipids play an important role in the interaction of blood platelets with coagulation factors as well as with the snake venom activator.

The chemical and physlcal properties of procoagulant membranes were further studied by determining the effect of varlation of the surface charge and kind of antonic lipld on the procoagulant activity of 
phospholipld vesicles (chapter V). Only if membranes contain phosphatidylserine as anlonic 11pld, the prothrombln-converting activity appearg to be yrtually independent of the surface charge of the vesicles. Veslcles with a net postelve charge cobtalned by introduction of gtearylanine) exhlbit procoagulant actuvity that is almost equal to that of vealeles th net negative charge. The results support a chelation model for the calclum-dependent assoclation of coagulation factors with membranes that contaln phosphatidylserine as procoagulant phospholipid. 


\section{SAMENVATTING}

In dit proefschrift wordt een onderzoek beschreven naar het mechanisme wan de doar Factor Xa gecatalyseerde omzetting van prothrombine in thrombine. De prothrombine-activering is zowel bestudeerd in modelsystemen met gezulverde fosfollpiden, als in aanezigheld van bloedplaatjes, de bloedcellen, die onder fyslologische omstandigheden geacht worden het procoagulante membraan te leveren.

Tijdens de omzetting van prothrombine worden de activatiepeptiden fragment 1 en fragment 1.2 gevormd. Deze peptiden bevatten het membraanbindend domeln van prothromblne. Ze kumen interfereren met de associatle van de verschillende componenten van het prothrombinasecomplex met de membraan en zijn daarom potentiele remmers van de vorming van thrombine. De experimenten in hoofdstuk II laten zien dat belde fragmenten de prothrombine-activering op het membraan inderdaad effectief remmen. Factor Va beschermt echter tegen reming, wat aangeeft dat in aanwezigheld van deze cofactor de prothrombine-omzetting via een ander mechanisme verloopt.

Prothrombine-activering kan ook gecatalyseerd worden door slangegifeiwtten. In Hoofdstuk III wordt de zuiverIng en karakterisering van de prothrombine-activator uit het gif van oxyuranus scutellatus (de Tafpanslang) beschreven. De prothrombine-activator aanwezlg in dit gif is een multumeer elwit dat bestaat uit een catalytisch deel, dat overeenkomsten heeft met Factor Xa, en een cofactor, die functoneert als Factor Va. Prothrombineactivering door de gifactlvator wordt anzienlifk versneld door fosfo11piden plus calclum, maar net door Factor Va.

De slangegffactivator is verwolgens gebrulke on de procoagulante plaat op het oppervlak van bloedplaatjes te karakteriseren. Humane bloedpladjes blifken de werking van het enzym te stimuleren. De resultaten gepresenteerd in hoofdstuk IV suggereren dat het Factor Xa-Va complex en de slangeglfactivator dezelfde procoagulante platsen op bloedplaties herkemen en dat megatief geladen fosfollplden een belangrifke rol spelen bly de interacte van bloedplaatjes met zowel de stolfactoren als met de slangegifactivator.

De chemlsche- en fysische elgenschappen van stolactleve membranen $z 1 j \mathrm{H}$ nader bestudeerd door bepaling van het effect van varlatie van de oppervlaktelading en variatie van het soort negatief geladen liplde op de 
procoagulante activitelt van fosfollplde vesicles (hoofdstuk v). Alleen Indlen menbranen fosfatidyloerine als negatief geladen ifplde bevatten blifkt de oppervlaktelading geen belangrijke parameter te zijn voor de prothrombinase-activitelt. Vesicles met een netto positieve lading (verkragen door incorporatie wan stearylamine) vertonen een procoagulante activitelt de vrijwel gelljk is aan die van vestcles met een netto negatileve lading. Deze resultaten ondersteunen een chelatiemodel voor de calclum-afhankelifke assoclatle van stolfactoren met membranen, die fosfatidy1gerine als procoagulant fosfollplde bevatten. 
CURRICULUM TITAE

De schrijver van dit proefschrift werd op 16 december 1957 geboren te Elndhoven. Na het behalen van het diploma Atheneum $B$ werd 1 1976 aangevangen met de studie scheikunde aan de Rijksuniwersiteit utrecht. In december 1979 behaalde hij het kandidaatsdiploma. In Januari 1984 werd het doctoral examen afgelegd met als hoofdvak blochemie (Prof. Dr. J. de GLer) en als bifvak fystologische chemle (Prof. Dr. Ir. J.S. Sussenbach). Van jul1 1984 tot jul1 1987 was hIj als medewerker van ZWO/MEDIGON werkzaam bIj de vakgroep Biochemie aan de Rijksuniversitelt limburg, waar onder lelding van Prof. Dr. R.F.A. Zwaal en Dr. J. Rosing het promotte-onderzoek werd ultgevoerd, dat geleld heeft tot deze dissertatle. Van Jull 1987 tot januari 1988 is hif als toegevoegd onderzoeker verbonden aan de Rijksuniversttelt Limburg * 